University of Louisville

ThinkIR: The University of Louisville's Institutional Repository

Electronic Theses and Dissertations

1939

\title{
The interpretation of the American Civil War in American fiction.
}

Florence Murray Bailey

University of Louisville

Follow this and additional works at: https://ir.library.louisville.edu/etd

Part of the American Literature Commons, Military History Commons, and the United States History Commons

\section{Recommended Citation}

Bailey, Florence Murray, "The interpretation of the American Civil War in American fiction." (1939).

Electronic Theses and Dissertations. Paper 1671.

https://doi.org/10.18297/etd/1671

This Master's Thesis is brought to you for free and open access by ThinkIR: The University of Louisville's Institutional Repository. It has been accepted for inclusion in Electronic Theses and Dissertations by an authorized administrator of ThinkIR: The University of Louisville's Institutional Repository. This title appears here courtesy of the author, who has retained all other copyrights. For more information, please contact thinkir@louisville.edu. 
TNIVERSITY OF LOUISVILIT

THE TITERPRETATION OF THE AMTRICAN CIVII WAR

IN AIERICAN FICTION

\author{
A Dissertation \\ Subritted to the Faculty \\ Of the Graduate School of the Iniversity of Louisville \\ In Partial Fulfillment of the \\ Requirements for the Degree \\ of Master of Arts
}

Department of English

By

Florence Nurray Bailey

Year

1939 
Name of Student: Forence Murray Bailey

Title of Thesis: The Interpretation of the American Civil War in American Fiction

Thesis Director: Dr. Ernest C. Hassold

Approved by a Reading Comittee Composed of the Following :

Date: June, 1939. 
ख

$n$

o

$\infty$

PREFACE

4935 


\section{PREREACE}

The large number of recent novels dealing with the American Civil Warl sugeested that it might be interesting to investigate the interpretation of the civil War in American fiction. Such an investigation should shed light, first, on the changes in the American mind in regard to its experience of a civil war and, secondly, on the functions of fiction in interpreting this experience through successive generations. The subject has been treated in part by other writers. Paul $\mathrm{f}_{\text {. Buck in The }}$ Road to Reunion, $1865-1900^{2}$ considers the changes in Axerican attitudes towards the Civil war for the period covered by his study. But his treatment of fiction is not exhaustive, nor does his book extend beyond 1900. A doc-

I In the last five years ten novels dealing seriously with the Civil War have been published: Stark Young, So Red the Rose (1934); Miackinl ay Kantor, Iong Remember $(1934)$; Margaret Mitchell, Gone with the Wind (1936); Hackinlay Kantor, Arouse and Seware (1936); Caroline Duff-Gordon, None Shall Look Back (1937); Royce Brier, Boy in Blue (1937); Clifford Dowdey, Bugles Blow No More (1937); Hervey Alien, Action at Aquila (1938); Villiam Faulkner, The Envenquished (1938); Allen Tate, The Fathers $(1938)$.

2 Paul F. Buck, The Roed to Reunion, 1865-1900

(Boston: Iittle, Brow and Company, 1937). 
toral dissertation ${ }^{3}$ by Rebecca Washington Smith catalogs aII the Civil War fiction published in periodicals or in book form between 1861 and 1899, but her study has a broader scope than this thesis has. Invaluable as both these studies are for the purposes of the present investigation, they leave room for a study of American fictional interpretations of the Civil War from 1861 to 1939. By "interpretation" here is meant a serious presentation of the conflict in terms of human experience. The following criteria were used in selecting pertinent material :

1. The fiction must be written on an adult level.

2. It must focus on the Civil War, not on its approach or aftermatb, and not use it simply as a backeround or something incidental to anothex theme.

3. It must deal with the war as general human experience, not simply as a setting for military or naval adventures.

of It must $E$ ive a sense of the cause and effects Iimiting the subject to fictional interpretations of the war eliminated a great deal of material: (1) juveniles, (2) melodramas, including tales of militery and naval

3 Rebecca Washington Smith, "The Civil War and Its Aftermath in American Fiction, 1861-1899, vith a Dictionary Catalogue and Indexes," (unpublished Doctor's dissertation, Chicago: Iniversity of Chicago, 1932). 
exploits, (3) love romances, and (4) fiction dealing with related problems such as slavery, reconstruction, reconciliation, and the rise of financial capitalism. 4 This study is restricted to fiction that has found publication in book form.

Analysis of the materials selected on this basis reveals a double shift from political to psychological preoccupation. It was natural that fiction written about the Civil War during the war or its aftemath in Reconstruction should be predominantly partisan, and that in the 'elghties and 'nineties partisanship should give way

${ }^{4}$ Typical cases of excluded material are:

Juveniles: W. Altsheler, Civil War Series; T. N. Page, Among the Camps (1891); T. I. Page, Two Iittle Confederates (1888); J. T. Trowbridge, The Drummer Boy (1863); J. T. Trowbridge, The Three Scouts $(1865)$.

Melodramas, including tales of military and naval exploits : Novels of John Is ten Cooke; G. W. Cable, Cavalier (1901); Novels of General Charles King.

Love romances: Novels of General Charles King.

Related problems : Slavery: I. M. Child, A Romance of the Republic (1867); Mark Twain, Pudd'nhead Wilson (1893). Religion: Elizabeth Stuart Phelps Ward, The Gates Ajar (1868). Reconciliation theme: Local color stories of J. C. Harris, T. N. Page and Constance Fenimore Woolson. Aftermath and reconstruction: $G$. W. Cable, John March, Southerner (1894); Mark Twrin, The Gilded Age $(1873)$; T. Dixon, Leopard Spots (1902); T. Dixon, The Clansman (1905); T. Dixon, The Traitor (1907); E. Glasgow, The Romance of a Plain Man (1909); T. N. Page, Red Rock (1898). 
to psychological reflection. It is not so self-evicent that fiction interpreting the Civil War to the twentieth century should be political in a new sense in the years between the Spanish-American War and the World War and psychological in a new sense after the World War.

Each of these four changes is discussed in a separate chapter. I have analyzed the fiction in considerable detail for three reasons: (I) many of the novels are not readily available; (2) I am using the individual work as illustrations of the unfolding pattern of America's changing understanding of the Civil War as that understanding 13 interpreted in fiction; (3) I wish to give a sense of the value of the individual works. 
TABLT OF CONTENTS

CHAPTER

PAGE

I. POIITICAI: PARTISANSHIP AND RECOITCIIIATION (1861-1879). . . . . . . . . . . . I 1

II. PSYCHOLOGICAI: REALISM AITD SENTTIEIVITIISM (1880-1899). . . . . . . . . . . 39

III. POIITICAI: WATION.IIISM AND HLMANITARIAIISM (1900-1919).................. 82

IV. PSYCHOLOGICAI : NATLRIISM AND INDTSTRIAIISM

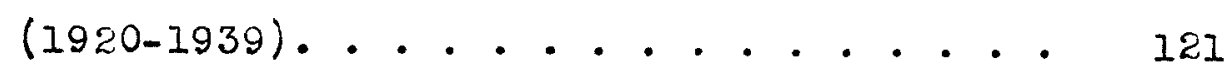

V. CONCLLSIONS .............. . . 1770 BIBLIOGRAPHY . . . . . . . . . . . . 179 
CHAPTER I

POIITICAI: PARTISANSHIP AID RECONCILIATION $1861-1879$ 


\section{CHAP TER I}

\section{POIIIICAL : PARTISANSHIF AND RECOINCILIATION $1861-1879$}

Betwe en 1861 and 1879 , eccording to my count, one hundred eighteen works of a fictional neture were written which deal with the American Civil War and wich have been published in book form. Apong the se are light romantic love stories, melodremas, stories giving accounts of military proceedines, local color s tories, and juveniles. I The se types of fiction do not give a serious presentation of the conflict in terms of human experience. Among these one hundred eighteen items there are only eleven novels which are interpretations of the war.

These fictional interpretations of the American Civil War are partisan and pamphlet-like in character. They are not psycholoeical studies of indiviouals in wartime, but they deal with sectional or netional problens in the spirit of champions of a cause. The experiences selected by the authors are representative rether then peculiar, common rather than individual. The selection is

\section{Most of the se are in Miss Smith's bibliography:} Rebeca Washington Smith, "The Civil far and Its Aftermath in American Fiction, 1861-1899, with a Dictionary CataIogue and Indexes," (unpublished Doctor's dissertation, Chicago: Iniversity of Chicaro, 1932). I have added a few. 
determined by the author's point of view. The treatment of the experience selected is marked by antithes is of sections and of social classes.

There are at least three points of view which have fictional spokesmen. To some Southern novelists the cause was that of States' Rights; to others it was the cause of the Southern Inionists. The former novelists are spokesmen of the slave-holding class which felt that the North was interfering with the economic growth and prosperity of their section and that the only condition under which the South could enjoy freedom and prosperity was outside of the union with the North. They belleved that a state had the right to secede if it wished to do so, hence the cause they fought for was that of States' Rights. 2 The latter novelists were spokesmen of the substantial, non-slaveholding class of Southemers who did not feel that the North was interfering with their freedom and prosperity. These Southerners, who were called Southern Lnionists, disapproved of secession and bemoaned the fact that a time had come when loyal citizens of the Inited States

\footnotetext{
${ }^{2}$ Southern Secessionist novels: Augus ta Jane Evans Wilson, Macaria; or The Altars of Sacrifice (2864); Charles Wells Russeli, Roebuck $(1866)$; R. H. Crozier, Confederate Spy; or, Startling Incidents of the War between the States $(1866)$; Iucy virginia Smith French, Fernwood; OI After Hany Deys (1867).
} 
were persecuted for their loyalty. These loyal citizens often lost both their lives and property at the hands of their fellow Southerners who looked upon the Southerm Tnionists as traitors to the South. The fictional spokesmen of this class wrote to publish these wrongs and to assure the North of some [nion sentiment in the South. 3 The poor white class in the South, who supported the secessionists in order to keep the negro in his place below them in the social scale, had a spokesman in humor, 4 but none in fiction. To the Northern novelists the cause to be fought for was the preservation of the Inion. 5 There is an interesting novel written by a Northerner in 1859 , two years before the war began. 6 It agrees with the later

3 Southern Inionist hovels: Isaac Kelso, The Stars and Bars; or. The Reign of Terror in Missouri (1863); Jeremiah clemens, Tobias WiIson (1865); A. O. Wheeler, Eye-Witness; or, Life Scenes in the Old Worth State (1865); William Mumford Baker, Inside: A Chronicle of Secession (1866).

4 Charles H. Smith, Bill Arp, So-Called, A Side Show of the Southerm Side of the War (New York: Metropolitan Record Office, 1866).

5 John William DeForest, Miss Ravenel's Conversion from Secession to Loyalty (1867); Henry Ward Beecher, Torwood: Village Life in Hew Fngland (1867); Mary J. Holmes, Rose Mather (1868).

6 John Beauchamp Jones, Wild Southern Scenes (Philadelphia: Petersen, 1859). 
Northerm novels in the belief that it was right to preserve the Cnion, but it describes the war as one in which the President of the Cnited States and the loyal citizens preserved the Inion against two groups of extremists, one Northern and the other Southern. Other Horthern attitudes had spokesmen among the humorists, but not among the novelists.7

- The four novels which interpret the war from the point of view of the Secessionists are definitely pamphlet-like in their purpose. Macaria (1864) by Augusta Jane Evans Wilson attempts to inflame the South to greater efforts by making the Southerm cause a sacred cause and by condeming the North. Roebuck (1866) by Charles Wells Russell trieg to prove the South right by stating the familiar arguments of the seceding states. Confederate Spy (1866) by R. H. Crozier was written to urge the South to establish her intellectual independence even though she has failed to win a political independence. It condemns

\section{C. F. Browne, Artemus Ward: His Book (1862):} R. H. Hewell, Orohous C. Kerr Papers (1862); D. R. Locke, Divers Views, Opinions, and Prophecies of Yours Trooly, Petroleum V. Iesby $(1865)$. 
the North and pictures Northern people very unfavorably. Kernwood (1867) by Iucy Virginia Smith French was written to assure the defeated South of its superiority to the North and to offer consolation by predicting a future success.

The facts about Macaria (1864) are an interesting revelation of the war atmosphere surrounding its publication. It was written by a Southern nurse during Sheman's march. Augusta Jane Evans 8 (not yet Mrs. Wilson) had published two novels before the war -- Inez (1858) and Beulah (1859). The soldiers called the camp where she nursed "Camp Beulah."

Macaria was printed by West and Johnson of Richmond, Virginia, on wrapping paper, bound, possibly, in

8 Augusta Jane Evans (1835-1909) was borm on May 4, 1835, near Columbus, Georgia. During her childhood she lived in Columbus, Georgia, in Galveston and $S a n$ Antonio, Texas, and in Mobile, Alabama. Her permanent home became Mobile. After nursing throughout the war, Augusta Jane Bvans, in 1868, married Lorenzo 11 . Wilson, who was then the president of the Mobile and Montana Railroad, and during his lifetime she wrote no more novels because he did not want her to over-tax her strength. She wrote Inez (1858), Beulah (1859), Macaria (1864), St. Flmo (1866), and, after her husband's death in 1879, The Speckled Bird and Devota. The last two novels do not rank so high as her earlier stories. - Lasalle Corbell Pickett, Literary Hearthstones of Dixie (Philadelphia and London: J. B. Lippincott $\mathrm{Co}_{0}$, 1912). 
gaily-figured wall-paper. 9 It became very popular among the Southern soldiers who felt, after reading it, that their sacrifices were made in a worthy cause. Among the Northern armies it was equally unpopular; one Federal officer seized and burned all the copies that he could find. However, the author wanted her interpretation of the war read in the North, and through her efforts it was published by J. B. Iippincott who, incidentally, induced another publisher to pay Augusta Jane Evans a royalty on the five thousand copies that that publisher had ready to issue.

Macaria is written in the style of Incle Ton's Cabin, the style of the domestic sentimentalists; that is, from a woman's point of view and filled with many tears, much religion, frequent discussions of right and wrong, and many references to classical Iiterature. Augusta Jane Evans found a classical parallel and named her book for

9 The publishers who fieured in those days below the Mason and Dixon line manufactured many volumes of a military character, printing on paper made from cotton and rags, and because of the chemical crudity, resulting in a poor quality of finish. . . Many Southern libraries still preserve books from this same firm (S. H. Goetzel), bound for want of better covers, in gaily figured wallpaper. - Moses, The Iiterature of the South (New York: T. Y. Crowell and Company, 1910), pp. 326-327.

Thomas D. Osborne, the donor of the copy of Hacaria which I borrowed from the library, wrote with pencil on a flyleaf that the book was written during the war 1861-1865 and was printed on brown Confederate paper. 
Macaria, the Grecien girl who had sacrificed her life to save Athens from invasion and subjugation. Augusta Jane Evans made two girls her central characters and made them "altars of sacrifice." Electra and Irene, the heroines of Macaria, found in the war a compensation for the happy married lives they both had been forced to forego. Electra had devoted herself to art, but during the war she nursed the soldiers and felt that she was serving a cause greater than art. Irene had made religion her strength, and the nursing of the soldiers during the war gave her an excellent opportunity to practice and teach what she believed. She felt that in serving the South, she was serving God, and that, while nursing the soldiers, she could bring them closer to God. Just after a Southern soldier died, Irene said: ". . He believed, and that comforts me. I have talked and read much to him during his illness, and found that he had no fear of eternity."I0 When the war was over, Electra and Irene, the "altars of sacrifice," were not simply resigned to their fate, but were happy that they had served the South.

In Macaria the Southern cause is made a sacred cause, one for which it was a privilege and a pleasure to

10 Augusta J. Evans, Macaria (New York: The F. M. Iupton Publishing Company, 1896), p. 396. 
sacrifice one's all, while the Northem cause is bitterly condemed. These quotations are very typical of the author's attitude toward the war. Irene said: "Another patriot gone -- another soul to bear witness before God against our oppressors and murderers."II At another time she said:

- I cannot, like Macaria, by self-immolation, redeem my country; . . but I yield up more than she ever possessed. I give ny all on earth - - ny father and yourself -. to our beloved and suffering country. My God! accept the sacrifice, and crown the Bouth a sovereign, independent nation! . . Goodby Russell! Do your duty nobly; win deathless glory on the battlefield, in defense of our sacred cause; and remember that your laurels will be very precious to ny lonely heart. 12

Augusta Jane Evans emphasized the wrong of the Northern side by making a Northerm minister, who had opposed secession, turn to the Southern cause because of his sincere belief in the righteousness of that cause. When asked why he was wearing a Confederate uniform, the minister replied that he objected to the dictatorship of Iincoln, that he believed that the North had violated Iiberty, leaving Iiberty only in the seven seceding states, and that he condemed the North for exposing the South to a servile insurrection by encouraging the slaves to desert their

\footnotetext{
$1 I$ Ibid., p. 396

12 Ibid., pp. 334-335.
} 
masters. THese, in part, are nis words:

I am a chaplain in a Texas regiment, and have been with the army from the beeinnine of these days of blood. At first it was a painful step for me; my affections, my associations, the hallowed reminiscences of my boyhood, a.lI I inked my heart with New York. . . - I loved and revered the tnion.. . Secession I opposed and regretted at the time as unwise; but to the dogma of consolicated government I could yield no obedience; and when every sacred constitutional barrier had been swept away by Iincoln -- when the habez.s corvus was abolished, and freedom of $\mathrm{s}$ peech and press denied - when the Washington conclave essayed to coerce fremen, to "crush Secession" through the aeen$c y$ of the sword and cannon -- then I swore allegiance to the "Seven States" where all of republican liberty remained.13

Thus, in a sentimental, rousing way, but from a woman's point of view, was the var interoreted in 1864 by a Southemer. Thus did Augus ta Jane Evens Wilson, in Macaria; or, Altars of Sacrifice, attempt to encourace and inflame southe mers to work and fight with renewed energy ïn a righteous, sacred cause.

Macaria is a woman secessionist's interpretation of the war written while the war wes still in proeress. Roebuck gives us a man's interpretation of the Southem cause, and it, too, was written during the war.

Charles Viells Russell (1818-1867), a Virginia scholar, teacher, and I awyer, wrote Roebuck "among the exciting scenes of the war, "although the book was not

\section{Ibid., p. 393.}


published until 1866.14 The story takes place in Virginia and in Washington, D.C., in 1861 and 1862. It has a complete outfit of conventional characters. 15 Julia Fairfax, the heroine, is the daughter of one of the First Farailies of Virginia. Her two suitors are Hugh Fitzhugh, a gallant Southerner, and pale, skulking albert Palmer, the son of a Massachusetts merchant who does $h$ is best to profit by the war. Of course, Hugh marries Julia. Also figuring in the story are good, humble Mark Marl in and his sister, poor whites, and a gentlemanly Inion officer who is nursed by Julia's family. The novel centers on the events in the lives of the Fairfax family whose plantation is called Roebuck. Their home is burned. Mr. Fairfax dies in a Federal prison rather than take an oath of allegiance to the Federal government. Julia's uncle is killed while trying to secure her father's freedom. Her mother dies of a broken heart. Her Hew Fingland suitor tries to force her to marry him by offering to save her father in return for her hand. The Mas sachusetts merchant wanted his son to marry a Southern girl while he himself clune to the Cnion, so that however the war turned out he would be prosperous.

14 Prof. A. T. Bledsoe, II. D., Editor of the Southern Reriew, "Biographlcal Notice" in C. W. Russell, Roebuck (Baltimore: Henry Taylor and Company, 1868).

I5 R. W. Smith, Dictionary Catalog. 
But Julia could not marry Palmer because she was engaged to Hugh.

Roebuck is extremely Southern in its sympathies and opinions. The Southern characters are everything desirable -- generous, gracious, good-mannered, refined, self-possessed, and intelligent. The Hew Fnglanders are the exact opposite - dishonest, bookish, and coldly formal in their manner. Is for the negro, Roebuck presents the typical Southem upper-class opinion. RusselI says that the negro race was intended by God to be held in slavery, that negroes are better off as slaves, that they are happier than the Nor the rn white laborers, that they are not capable of ruling themselves, and that the masters are really the slares because they must care for the black race. Russell interprets the war as a war in which the cheap, mercenary Northerners were trying to interfere with the ideal civilization of high-minded Sou the rners.

So, during the war Augusta Jane Evans Wilson urged the South on to greater effort, and Charles Wells Russell stated the Southern case. The other two Secessionist interpretations were written after the war. They, too, represent a man's and a wom's opinions.

R. H. Crozier was among the defeated but unconvinced Southerners. He wrote to compete with Northerm 
writers and hoped that the South could establish her mental independence even though she had lost her political independence. Confederate Spy (1866) was his first novel. In the Preface, written in Panola County, Nississippi, on May 28, 1865, be says that he:
- . submits the book to the judgment of the patriotic Southern public with the hope that it may help to supplant the poisonous Northern Iiterature which has for so many years flooded the South, and villified the Southerm people and their institutions. The time has now come when there ought to be a change. The South must have a literature of her own. If we could not gain our political, let us establish at least our mental independence.

Besides promoting a Southern literature, Crozier had another purpose in writing $h$ is first novel. He wanted to express his contempt for the North, and in the novel he presents the North in as unfavorable a light as he could. He tells us in the Preface that the story is almost a narrative of facts, and he apologizes for the profanity by saying that Mankee character cannot be correctly delineated without it."

In 1885 Crozier wrote a preface to a fifth edition of the book, which was published in Louisville. Between the fourth and fifth editions he had become a minister, and there is on interesting softening of his attitude toward the North in the new preface. He again apologizes for the profanity and says that, except for the Southem 
demand for the book, he would have let it go out of print. In this preface he says that the profanity cannot be omitted without changing the true picture, not of Yankees, this time, but of military men. The purpose of the book, according to this preface, was to show in what manner the war was conducted. Since the profanity was used by Yankee military men and not by Confederate and since the book shows the war conducted in a villainous way by the North, his changed wording thinly veils the bitterness whlch he evidentiy still felt. At the end of this preface he speaks more plainly:

Henry Winston and ily Burrell are exponents of Southe rn sentiment and true types of Southern character and as such they mast kindle the patriotic emotions and awaken the sympathy of every Southerm man, or woman, who reads this volume. Our Northern brethren have sent forth many books more abusive than this. It is only just and fair to accord to us the privilege of defending ourselves by stating our side of the question at is sue.

But we have said enough, and "with malice toward none" we send forth another edition of the "Confederate Spy," hoping that it will be interesting and useful to readers generally.

Crozier intended Confederate Spy to be a realistic picture of the war as it entered the experience of Bmily Burrell, the representative of the best in Southern women, and Fenry Winston, the Confederate spy and a Southern gentleman. However, al though Crozier had served as captain 
of a regiment of Mississippl volunteers and had firsthand experience to record, his novel is sometimes melodramatic and his viewpoint sometines too obviously prejudiced. He was young in years, inexperienced as a writer, and too much influenced by partisanship. 16

The story is briefly this: Just before the beginning of the war Bmily Burrell of Kentucky falls in love with Henry Winston of Mississippi. At the end of the war, after both have suffered from misunderstandings and wartime hardships made worse by the Northern villain, Walter Hallam, they are married and go to Cuba for safety from the North.

The book interprets the war as a conflict in which the barbarous North, composed of villains and ignorant, contemptible foreigners and ruled by a drunkard, defeated the "Goddess of Iiberty," as Crozier calls the South. Crozier makes the Northern soldiers act like thieves and talk like ignorant Irish or Dutch. Iincoln is made to perform as a drunken dupe. Crozier refers to one Northem leader as General Robespierre and to another as Colonel Nero. He quotes Abu-Bekr's instructions of twelve hundred

16 Biographical facts are from the prefaces in the fifth edition of the novel, R. H. Crozier, The Confederate Spy (Louisville: John P. Morton and Company, 1885). 
years ago against barbarism and accuses the Yankees of violating them all. Finally, Crozier is amusing in his dramatic farewell to Iiberty and the Confederacy. He tells the "Goddess of Liberty" to tell all her wrongs to Washington, Andrew Jacks on, Calhoun, and Webster when she sits with them in paradise: "Tell all this, Goddess of Iiberty, and Washington, and Jackson, and Calhoun, and Webster will weep tears of blood, even in heaven." 17 The novel closes with a farewell to the confederate flag. The poem quoted is by Father Ryan.

Poor Colonel Fllsworth fell in the very first battle in which he was engaged for the defense of southerm honor. He was a noblehearted man, and deserves the gratitude of all true southem patriots. Requiescat in pace. Iet him rest with all other Confederate heroes, who have spilled their blood for liberty, under the drooping folds of the Confederate flag. It is their winding sheet. Glorious banner! we lay thee down, bloodstained, with emotions ineffable. Thy "stars and bars" are destined no more to wave over the southern I and. Thou art furled forever!

Honored flag! we take a mournful leave of thee in the following beautiful lines of an American poet -a just tribute to the cause of which thou art the emblem:

Take that banner down; 'tis weary--

Round its staff' tis drooping dreary:

Furl it, fold it, let it rest;

For there's not a man to wave it,

For there's not a sword to save it,

In the blood that heroes gave it;

And its foes now scom and brave it:

Furl it, hide it, let it rest.

17 R. H. Crozier, Confederate Spy, p. 400 
Take that banner down; 'tis tattered -Broken is its staff, and shattered; and the valiant hos ts are scattered over whom it floated high. 0 , 'tis hard for us to fold it, Fard to think there's none to hold it, Fard that those who once unrolled it, Now must furl it with a sigh.

Furl that banner -- furl it sadly;

Once six millions hailed it gladly, And ten thousand, wildly, madly,

Swore it should forever wave

Swore that foeman's sword should never Hearts Iike theirs entwined dissever; And that flag should float forever o'er their freedom or their grave.

Furl it, for the hands that grasped it, and the hearts that fondly clasped it, Cold and dead, are lying low; And that banner, it is trailing, Wile around it sounds the wailing of its people, in their woe. For, though conquered they adore it; Love the cold dead hands that bore it; Pardon those who trail and tore it; 0 , how wildly they deplore $1 t$, Now to furl and fold it so!

Furl that $b$ anner; true 'tis gory, But 'tis wreathed around with glory, and ' $t$ will live in song and story. Though its folds are in the dust: For its fame, on brightest pages, Penned by poets and by sages, Shall go sounding down the ages -Furl its folds though now we must.

Furl that banner, softly, s lowly; Furl it gently -- it is holy, For it droops above the dead: Touch it not, unfurl it never; Let it droop there, furled forever, For its people's hopes are fled! 18 
Kemwood; or, After Many Days (1867), the last Southern interpretation published in this period, is written from a woman's point of view. Lucy Virginia Smith French, the author, gave encouragement to the defeated South in her novel which was published in Louisville, Kentucky, in 1867. Lucy Virginia Smith French had not always sympathized with the South. Although a Southerner, born on March 16, 1825, in Virginia, she had been educated in Pennsylvania. Then she was employed as a teacher in Memphis, Tennessee. She probably understood both the Northern and the Southern points of $v$ iew; but, when she saw the war approaching, she became a warm supporter of the Inion, and during the war she wrote in behalf of its restoration. Wile teaching in Tennessee, she wrote for the Iouisvilie Joumal under the pen-name of I'Inconnue.19 After the war her Southem blood must have triumphed over her political convictions or she played to a prevailing mood, for Kemwood gives both sympathy and encouragement to the South.

Kemwood is a sentimental novel which interprets the war as a war in which the south nobly and willingly fought for liberty. The justice of the Southern cause is

19 Biographical facts from Dictionary of American Biography (New York: Charles Scribner's Sons, 1928). 
emphasized by the use, as the central character, of a British woman, a professional spy, who came to America because she thought that her services were needed in the South. Amanda Douglas, the spy, had served with Florence Nightingale in the Crimean War before coming to America to offer her services to the Confederate War Department, which made her the captain of an organized band of spies. During the Civil War she secused inforration for the Confederacy by passing through the Federal lines disguised as an Irish vegetable peddler or as an Irish woman trying to sell a bale of cotton. Corinne Houghton, Amanda's American cousin, also served as a spy during the war. Corinne is the connecting $l$ ink between Amanda and the other principal characters. Corinne was a neighbor to Colonel Courie and his family, who had moved from Louisiana to Kermwood, an estate in Temessee, in order to benefit the health of Mrs. Courie. The Courie family represent the planter aristocracy. When the war came, Corinne and the Courie family expressed joy in the secession of their state and planned to serve the South to the utmost. Colonel Courie led a regiment, Corinne became a spy, and Eloise served at home. Mrs. Courie had died. In addition to these characters, there is another group who carry on a story not related to the war. Hloise's governess, Miss 
Cora, was really the daughter of a good family and the wife of a gentleman; but being separated from her husband by a trick of fate, she had left Pauline, their daughter, to be raised as a foundling by a wealthy Southern family. The events which lead to the discovery of Miss Cora's identity and to the re-uniting of the little family form a plot running through the novel along $w i$ th the adventures of Amanda in the war.

L'Inconnue's interpretation of the war is interesting in that it encourages the south, not by dwelling on the righteousness of their cause, but by telling a pleasant story shot through with a Confederate spy's clever doings in deceiving Federal soldiers. There is no doubt in the book that the South was right and the North wrong. Near the end of the last chapter Iucy Virginia Smith French says :

We have been through the war, and peace is again restored to our country; but liberty is crushed, and the "end is not yet." The justice of our defeat is known only to the High Ruler of the Cniverse, and we dare not question, but submit;...20

The promise that the South will $\mathrm{rise}$ again and demand redress is also interesting. The author says:

We are a vanquished people, but yet not utterly prostrate, for

20 I.V.S. French, Kernwood (Iouisville, Kentucky: Published for the author by John P. Biforton and Company, 1867), pp. 389-390. 
"There is life in the old land yet";

and phoenix-like, it will rise from the ashes of the past and lift its voice for redress. The rights of the Southron may slumber, and evil men have power for a while, and poverty and sorrow fill our hearts, but

To the defeated South in 1867 Kernwood should have been a very soothing story.

Macaria, Roebuck, Confederate Spy, and Kermwood are based on the belief that secession was right. In contrast to these we have the novels of the Southern Cnionists who say, in effect, "Secession is one crime of the Secessionists, and the persecution of loyal citizens is another." Iike the Secessionist novels, these novels are pamphletlike in their purpose. We shall discuss Tobias Hilson by Jeremiah Clemens, and, having established a pattern, we shall then sumarize the interpretations given by the other sou them Inionist novels.

Jeremiah Clemens (1814-1865) wrote Tobias Wilson, $\underline{A}$ Tale of the Great Rebellion because he wanted to leave a record of the wrongs which he and other Southern tnionists in the South suffered at the hands of irregular Confederate troops. Clemens says:

Nothing is depicted here which did not occur
a related, or which has not a parallel in sone other

$$
21 \text { Ibid.., p. } 390 .
$$


actual occurrence. - . property taken or destroyed - . their persons constantly threatened with incarceration, if not with assassination,.. . their sons drageed to the slamghter-pen . . . the sending of our wives in to exile, wi thout the means of subsis tence, and dependent for bread upon the charity of the people of the North, or of such chance refugees who had escaped under happier auspices, . . .22

Jeremiah Clemens, a veteran of the war for Texan independence and of the war with Mexico, $\varepsilon$ novelist, end a senator, had been forced, in 1862, to leave his home in Huntsville, Alabama, because of his trionist tendencies. He went to Philadelphia where he wrote Tobias Wilson and whe re he conducted a pamphlet campaign against his atate. In 1864, he advocated the re-election of Iincoln. Tobias Vijison was published by the J. B. Iippincott Company (the same company that published Macarie, 1864) in Philadelphia in 1865, probably while clemens was still living there. However, he returned to Huntsville, Alebama, toward the close of the war and died there on May 21, 1865, 2 few weeks after peace had been declared. 23

The theme of the novel is the persecution of Southern Cnionists in the South by irregular Confederate troops. Tobias Wilson's grandfather, a sixty-five year old Cnion

22 J. Clemens, Tobias Vilson (Philadelphia: J. B. Lipp incott and Company, 1865), Preface. Biography

23 Biographical facts from Dictionary of dmerican 
sympathizer living peacefully on a farm in the mountainous part of northern Alabama, was murdered by three Southerm marauders called partisan rangers (the worst materials in the Confederate army, Clemens says) who wanted his cabin for the ir headquarters in case the Inion forces came into that section. His death is revenged by Thomas Rogers, a friend and neighbor of Tobias. Thomas revenged the death for two reasons -- he feared his own father's life was in danger, and, because of his sister, be did not want Tobias to do it. Toblas and Sophy Rogers were engaged to be married, but Sophy believed that vengeance belongs to God and she would not have married Tobias if he had undertaken to execute the vengeance. She could forgive her brother. In this part of the novel Clemens was influenced by the domestic sentimentalists, but the main part of the story follows realistically the movements and manoeuvers of the irregular troops, in showing how Thomas finally got his revenge. The house of Thomes Rogers, Sr., wes surrounded one night and accidentally set afire. A few things were saved, but the house was burned to the ground. Tobias, who was living there at the time, was taken prisoner but escaped. After this event Thomas Rogers, Sr., Sophy, and Tobias's mother were sent to the North for safety. After the death had been avenged, Tobias and his friend fought 
in the trion army. The story ends before the war is over. That is the realistic picture which Jeremiah Clemens gives of the war. He resists the interpretation given by Sou the rmers like Augus ta J. T. Wilson. To him the war was something which demorelized some of the Southern peo- ple -- the ones who joined the irregular bands -- and caused them to persecute Southern Inionists. The attitudes of the other three Southem Cnionist novels may be sumarized briefly. The books are dedicated to the generals and soldiers of the tnion amy and to loyal Southerners. In prefaces the anthors state that the narratives were written among the scenes described and are true accounts of what occurred. The purpose of the arthors in recording the events was twofold -- to assure the North of Cnion sentiment in the South and to reveal the shocking crimes comitted by disloyal Southemers. Their novels decry the presence of slavery in the South. They present the secessionists as ignorant or stupid people, as drunkards, end as politicians out for personal gain. This is obviously not a complete picture of Secessionists, but it is an easily understood picture when we remember that there was bitter resentment over personal injuries rankling in the breasts of these authors. The author who speaks best of the South says that he loves the South, but 
that he loves the nation more. 24 In their bitterest tems these Southerm Inionis ts define the war as a deadly struggle between civilization and barbarism, between freedom and slavery, between republicanism and aristocracy, and between loyalty and treason. 25 In their mildest tems they define the war as something which brought a better Iife to the South by destroying slavery. 2.6

The Southern Secessionists interpreted the war as a war for liberty. The Southern Cnionists interpreted it as a war which was caused by Southern hotheads and which brought terrible suffering to many loyal citizens. We have yet to discuss the Northern interpretations of the war. They were written more for the purpose of entertainment and less for the purpose of pamphlets than were the Southern novels.

The three novels written from a Northern point of view are variations on the theme that secession was wrong and that it was, therefore, right to preserve the Union. Rose Mather (1868) by Hary Jane Holmes makes the preserv-

24 William Murnford Baker, Inside (New York: Harper and Brothers, 1866), Preface.

25 Is aac Kelso, The Stars and Bars (Boston: A. Williams and Company, 1863), Preface.

26 William Mumford Baker, Inside. The hero, $a$ minister and probably Baker's spokesman, expresses this opinion. 
ing of the Union a religious cause, just as lacaria made the southern struggle for freedom a religious cause. Norwood: Village Life in New Englend (1867) by Henry Ward Beecher magnamiously finds excuses for the mistaken and misguided South wich seceded and caused a war. Miss Ravenel's Conversion from Secession to Loyalty (1867) by John William DeForest presents the Northern arguments and atterp ts to record and to evaluate one incident in the North's preservation of the tnion, the freeing of the slaves. We shall discuss these books in order.

Rose Mather was written by a Northern woman, Mary Jane Holmes, 27 and is dedicated "to the soldiers Iivine and the merory of the soldiers dead." Iike Macaria, it is written in the style of the domestic sentimentalists. The novel pictures wartimes in a New York village and in the Inion army. In Miss Smith's woras it is:

- a picture of hearts and homes, wherein a rich girl, Rose Mather, leams the lessons war teaches: to give up her husband to her country, to share the Eriefs of the poor, to work for the Sanitary Cormission, and to accept religion. 28

27 Mary Jane Hawes Holmes (April 5, 1825 - October 6. 1907) was borm in Brookfield, Massachusetts. After her marriage to Daniel Holmes in 1849 she spent most of her Iife in Brockport, New York, el though she and her husband lived for a short period at Versailles, Kentucky. -- Dictionary of American Biography.

28 R. W. Smith, Dictionary Catalog. 
The story is laid chiefly in the New York village, but the scene shifts occasionally to describe battles and the horrors of prison life in Iibby, Belle Island, and Andersonville. It also leaves the village to show a quaker family nursing a tnion soldier, a member of the Masonic Order helping a fellow-member, and a family of Southerm Cnionists aiding tnion soldiers.

This author interprets the war as a religious cause, a cause for which Northemers willingly and cheerfully sacrificed their all. On the first page Mary Jane

Holmes says :

The Ione disputed point as to whether the South was in eamest or not was settled, and through the Northerm States the tidings flew that Sumter had fallen and the war had commenced. . . Political differences were forgotten. Republicans and Democrats struck the friendly hand, pulse beat to pulse, heart throbbed to heart, and the watchword everywhere was, "The Inion Forever." Throughout the length and breadth of the land were true, loyal hearts, and as at Rhoderic Dhu's command the Highlanders sprang to vie from every clump of heather on the wild moors of Scotland, so when the war-cry came up from Sumter our own Highlanders arose, a mighty host, responsive to the call.29

The identification of the war with religion is emphasized by the author's comment on a church's being the place of the village's first war meeting:

- . a dense and promiscous crowd wended its way

29 M. J. Holmes, Rose Mather (New York: G. W. Dillinghem, 1896), p. 9 . 
to the old brick church, whose hallowed walls echoed the sound of fife and drum, strange music for the house of God, but more acceptable, in that dark hour, than songs of praise sung by vain and thoughtless Iips. 30

It was religion which enabled the women to send their husbands to the war:

There was a terrible struggle going on in Annie Graham breast, outy to her country and love for her husband waging a mighty conflict, the former telling her that if the rigint would triumph, somebody's husband must go, and the wife-heart crying out, "Yes, somebody's husband must go, I know, but not mine, not George. 31

Anon, however, something whispered to her that the God she loved was on the field of carnage, and in the camp and in the hospital, and everywhere as much as there in Rockland, that prayers innumerable would follow the brave volunteers, and that the evil she so much feared might be the means of working the great good she so desired. And thus it was that Annie came to a decision. 32

The religious interpretation of the idea that it was right to preserve the Inion dominates the picture of the war in Rose Mather, but there is also some of the magnanimous tolerance which we shall find so prominent in Beecher's Norwood. The war is often explained in Rose Mather as the result of a lack of understanding between the people of the two sections. Note this conversation
30 Ibid. , p. 30
31 Ibid., p. 12 .
32 Ibid., p. 25 
between a Tnion and a Confederate soldier:

"Whose government will answer for all this, yours or the one that I acknoviedge?"

"Both, both!" Tom replied Vehementiy; and the stranger rejoined:

"Yes, both have much to answer for, -- one for not yielding a little more, and the other for its rash impetuosity. Oh, had we, as a people, known each other; could we have guessed what brave, $k$ ind hearts there were both North and South, we should never have come to this; but we believed our leaders too much; trusted too implicitly in the dastardly falsehoods of a lying press; and it has brought us here." 33

Norwood (1867) was written by Henry Ward Beecher (1813-1887), 34 a Congregational minister and a brother of Harriet Beecher Stowe (1812-1896). In 1863 Beecher visited England and was successful in wimning many sympathizers to the Northern cause. Norwood, however, was

\section{Ibid., 108.}

34 Henry Ward Beecher was born in Iitchfield, Connecticut, June 24, 1813, the eighth child of Iyman Beecher and Roxana Foote Beecher. Lyman Beecher was a Coneregational minister, who attained in his day an eminence scarcely less than that which his son later attained. Henry Ward Beecher's first pastorate was the Presbyterian Church at Iawrencebure, Indiana. From there he went to a Presbyterian Church in Indianarolis, Indiana. From 1847 until $h$ is death in 1887 he was the minister of the Congregational Church in Brooklyn. New York. That church became famous as "Beecher's Church." -- Biographical facts from Iyman Abbott, Henry Ward Beecher (Boston and New York: Houghton Miffl in Company, 1904), and Harriet and Percy Fitzhugh, Concise Biographicel Dictionary, (New York: Grosset and Dunlap, 1935). 
written simply because Beecher had promised a publisher that he would write a story about the war. The story expresses a tolerant attitude toward the South.

The theme of Norwood is village I ife in New Ingland during the war. In choosing and developing that theme Beecher shows the influence of the local colorists, who were beginning to appear in American literature. His famous sister was one of the local colorists. The heroine of Norwood is Rose Hentworth, the daughter of a New England doctor. The hero is Darton Cathcart, the son of another New England family. Barton goes to war, is injured, is nursed by quakers, and finally returns and marries Rose. There is nothing unusual in that; but, Barton has a sister Alice who at the beginning of the war is in love with Tom Heywood, a Southerner. That is one place where Beecher can introduce tolerance. Alice was inclined to feel that Tom was too noble to be led into a war against the Inion, but Beecher has Dr. Wentworth exolain:

". . The State feeling is stronger than the national. . . Our friend Heywood is honorable, and will resist disunion; but when he sees it accomplished, he will sowith his state, and probably join the southern army." 35

Tom does join the Southern army and is killed. Alice

\section{$35 \mathrm{~F}$. W. Beecher, Norwood (New York: Fords,} Howard, and Hulbert, 1392$), p .406$. 
learns to understand the Southern side of the war and goes south after the war to teach the negroes. Various types of New England people are represented in Norwood. There are educated, uneducated, rich, and poor, but all accept the war as a sacred cause just as the people in Rose Mather did. The men fight, some of the women (the three most important women characters) go to the front to nurse, and the stay-at-homes give all the assistance that they can offer to help preserve the Inion.

Norwood interprets the war as a struggle which preserved the Cnion and, incidentally, freed the slaves, but more than this it interprets the war as a struggle caused by the mistaken South whom the North must generousIy forgive. Beecher says that at the end of the war:

[The brave men of the North] in their admiration felt that the heroism of that army was the only worthy measure of the perseverance and bravery of the Army of the Potomac. In every generous bosom rose the thought -- "These are not of another nation, but our citizens." Their mistakes, their evil cause, belonged to the system under which they were reared, but their military skill and he roic bravery belong to the nation, that will never cease to mourn that such valor had not been expended in a better cause; and that the iron pen must write: "The utmost valor misdirected and wasted." 36

John William DeForest (1826-1906), in Miss

Ravenel's Conversion from Secession to Loyalty (1867), is

36 Ibid., p. 450. 
not concerned with tolerance as Beecher was, nor does he base his interpretation of the idea that it was right to preserve the Inion on religion as Holmes did. He interprets the war as a victory for the cause of liberty. DeForest was the son of a successful merchant and cotton manufacturer. When the war began, he was in Europe. Returning to America immediately, he became the captain of a. company which he recruited in New Haven, Connecticut. He served under Generals Weitzel and Banks in the Southwestern states, and under General Sheridan in the Shenandoah Valley. He also held the positions of inspectorgeneral and aide and was brevetted major on March 13, 1865. After the war he received several military assignments, one of which was the command of the Freedman's Bureau, with headquarters at Greenville, South Carolina. His military service, however, did not prevent his doing some literary work, for he wrote some vivid descriptions of battle scenes for Harper's Monthly and in $186^{\prime 7}$ he published Miss Ravenel. He was mustered out of the service on January $1,1868.37$

DeForest's novel is as masculine as Mary Jane Holmes' is feminine. Miss Ravenel is realistic. It has a 37 Biographical facts from Dictionary of Arnerican
Biography. 
practical, unemotional tone unusual in novels of this period. Mr. Carl Van Doren, in The American Novel, describes it in the following phrases:

- coldly truthful in its descriptions of bat-
tles and camps, crisp and pointed in its dialogue,
penetrating, if not over-subtle, in its character
analysis, sensible in its plot, and in its general
temper alert and sophisticated, it is still gimost as
convincing as it was once precocious. - . .

The theme of Miss Ravenel is just what the complete title states -- Miss Ravenel's conversion from secession to loyalty. Shortly after the Fort Sumter excitement Dr. Ravene1, a Southerner, who would not be a Rebel, with his daughter, Lillie, moved from New Orleans to New Boston, an imaginary New England city in an imeginary state. Dr. Ravenel did not approve of slavery or of secession, but his daughter did. Miss Ravenel continued to be a rebel for awhile because New Orleans was her home and her friends Iived there. However, when Iieutenant Colonel Carter, a Northern officer but a Virginian of "Colonial blue blood" descent and a West Point graduate, and $\mathrm{Mr}$. Edward Colburne, a young Northem soldier and lawyer, became her friends, she was gradually converted. Miss Ravenel married, first, Carter, who is unfaithful to her and is killed in battle; some time afterward she married Colburme whom

\footnotetext{
38 Carl Van Doren, The American Novel (New York: The Macmillan Company, 192I), p. 129.
} 
she and her father had nursed back to health after his service in the army.

The book presents several phases of the life of the period. The Southerm social graces represented by the Ravenels and Colonel Carter are contrasted with the seeming stiffness and awkwardness of the Hew Fngland people. The campaign in the Southwest is described realistically, not heroically. In the scenes of camp life and battles we get a picture of the cowardice and dissoluteness which sometimes occur in high places. Colonel Carter is an unprincipled officer. Colburne, who begins and ends a captain, deserves the promotions which go to a coward who is more important politically. Another phase of the life of the period is seen in Dr. Ravenel's experiment with free negro labor on a New Orleans sugar plantation. The negroes were paid for their services, and Miss Ravenel tried to teach them to read. Dr. Ravenel was pleased with the project, but he had to abandon it when the contending armies came too close.

This novel is realistic, but when it comes to evaluating the war itself, Dr. Ravenel and Colburne, who must be DeForest's spokesmen, give a most extravagant and partisan description of what the North accomplished. Dr. Ravenel and Colburne think that the North has reason to 
break out with "national vanity" over Burope's praise of her service for freedom in freeing the slaves, or to sprout peacock tails as expressions of their consciousness of admiration. They think that Europe is right, for they have acted--

- . the fifth act in the grand drana of human liberty. First, the Christian revelation. Second, the Protestant reformation. Third, the War of American Independence. Fourth, the French Revolution. Fifth, the struggle for the freedom of all men, without distinction of race and color. 39

Colburme and Ravenel agree that the North won because "right conquers"; they add that right conquers because "right nakes might" and a just system of labor produced power while an unjust system produced weakness. They say that the North, in its righteous living, developed character -- for example, "Iincoln, a purer, wiser, and greater than Socrates, whom he reminds one of by his plain sense and homely humor"; and they say that the Southern character will be improved by the struggle, -- will be sweetened by adversity. 40

Then, in Miss Ravenel DeForest interprets the war

39 J. W. DeForest, Miss Ravenel's Conversion from Secession to Loyalty (New York: Harper, 1867), pp. 494495 .

40 Ibid., p. 496. 
as a glorious service performed by the North for Freedom, for our country, and for the South. 41

We have now discussed all the fictional interpretations of the American Civil War which were written before 1880. It may be noticed that these novels were written before 1870. Why are there no other interpretations be-

41 It is interesting to compare DeForest's interpretation of the war with that of tiysses $\mathbf{S}$. Grant:

There was no time during the rebellion when I did not think, and often say, that the South was more to be benefited by its defeat than the North. The latter had the people, the institutions, and the territory to make a great and prosperous nation. The former was burdened with an institution abhorrent to all civilized people not brought up under it, and one which degraded labor, kept it in ignorance, and enervated the goveming class. With the outside world at war with this institution, they could not have extended their territory. The labor of the country was not skilled, nor allowed to become so. The Whites could not toil without becoming degraded, and those who did were denominated "poor white trash." The sys tem of labor would have soon exhausted the soil and left the people poor. The non-slaveholder must have sold out to his more fortunate neighbor. Soon the slaves would have outnumbered the masters, and, not being in sympathy with them, would have risen in their might and exterminated them. The war was expensive to the South as well as to the North, both in blood and treasure, but it was worth all it cost. -Clysses 3. Grant, Personal Memoirs of $\underline{\text {. }}$ S. Grant (New York: C. I. We bs ter and Corapany, 1885-1886), II, pp. $39-40$. 
tween 1861 and 1879? Wasn't the country writing about the war? Yer, the re was much more war fiction than just these eleven novels, $4 I$ but as far as I have been able to find out these are the only interpretations. After the war there was a widespread desire to for fering. Editors did not encourage Civil War stories. Instead they wanted local color stories which led to a better understanding between the hostile halves of the nation. That is what the authors of fiction began to write. 42 So, for the interpretations of the war in this period we must turm to eleven novels, written before 1870 . While most of the features of this fiction belong strictly to the period in which it was written, a few of its innorations became conventional patterns in later fiction. They are: (I) the sharp distinction between Northemers and Southerners found generally throughout all thes novels, (2) the use of intersectional marriage found in Miss Ravenel, and (3) the Iincoln legend, the picture of Iincoln as a kindly patriarch dispensing succor to all who ask, found for the first time in Norwood. We must

41 Miss Smith's Dictionary Catalog shows an almost continuous flow of Civil War fiction.

42 P. H. Buck, The Road to Reunion, 1865-1900 (Boston: Iittle, Brown and Company, 1937), p. 5. 
wait, however, for twenty years before we find them in fictional interpretations of the war. The next period, from 1880 to 1899 , is a period of short stories dealing with individual psychology and having very little to say about the sectional nature of the conflict. 
CHAPTER II

PSYCHOLOGICAI : REALISM AND SEITIIEITALISM $1880-1899$ 


\section{CHAPTER II}

\section{PSYCHOIOGICAI : REALISM AND SEVTTIMENTAIISM}

$$
1880-1899
$$

For the years from 1880 to 1899 I have found over two hundred books of fiction dealing with the American Civil War. They include love romances, adventure stories, local color stories, juveniles, and stories dealing with themes merely related to the war. In the first decade of this period, as in the eighteen-seventies, editors and publishers were encouraging fiction wich promoted reconciliation between the hostile halves of the nation in preference to fiction which interpreted the war. I have found only eleven interpretations written during these twenty years. They include two novels and numerous short stories by Northerm authors, and two volumes of short stories by Southem authors. Tnlike the interpretations of the 'sixties wich have been almost completely forgotten, some of this fiction has come to rank with the best American literature. The most outstanding are Stephen Crane's novel, The Red Badge of Courage (1895), and Ambrose Bierce's short stories, Tales of Soldiers and Civilians (1891) (later changed to In the Midst of Iife) and Can Such Things Be? (1893). The other Northern inter- 
pretations include a novel, In War Time (1884), by Silas Weir Mitchell; one short story, "The Return of a Private" (1891), by Hamlin Garland; three volumes of short stories, The Copperhead (1893), Marsena (1894), and The Deserter (1898), by Harold Frederic; and one volume of short stories, Iittle Regiment and Other Bpisodes in the American Civil $\operatorname{Far}(1896)$, by Stephen Crane. The Southern interpretations, not so numerous and not so well known, include The Burial of the Guns and other Stories (1894) by Thomas Nels on Page and Southem Soldier Stories (1898) by George Cary Eggleston.

In contrast with the early partisan interpretations of the American Civil War, the fictional interpretations between 1880 and 1899 are primarily realistic, psychological analyses of war experiences. They do not mirror the whole scene of the war, but give, usually in short story form, flashlight vie of unrelated parts of the scene. The Southern stories are about Southerners and the Northern ones about ITortherners, but the sectional reference is merely incidental. There is no bitterness. The attitude toward the war, especially in the Northem stories, is decidedly unromantic, although the stories may be humorous, weird, pathetic, or tragic. Further than this it is hard to characterize the interpretation of the war in this 
period. Each flashlight view of the war seems to say, "War was this." In this fiction war is many things, end we are left to examine the fiction itself. We shall take, first, the tro novels, which are Northerm, then the Northem short stories, and last, the southern short stories.

In War Time (1884) by Silas Weir Mitchell is a novel which interprets the war chiefly through a psychological analysis of one individual. Mitchell (1829-1913), a native of Pennsylvania, was well-equipped to write such an interpretation. In addition to his literary activities he was one of the most eminent of medical specialists, particularly in nervous diseases.l This special knowledge enabled him to write authoritatively of difficult and wayward states of body and mind. For three years during the war he served as army surgeon in the FiIbert street Hospital in Philadelphia, the hospital which he describes in In War Time. Mitchell also had first-hand experience

I On the advice of Oliver Wendell Holmes, Mitchell early set aside his Iiterary ambitions until he should have established himself in a profession. Only after Mitchell was fifty years old did he give much time to verse or fiction, which he produced from that time with no diminution of power until the very year of his death. -. Carl Van Doren in Cembridge History of American Literature III, 90 . 
for the part of his story which takes place in Europe. In 1864 his health broke and he went to France and England for a rest. There, as he records in his novel, he found sympethy decidedly with the South.

In War Time (1884) has been called "one of the best novels about the Civil War in American fiction before 1899."2 The story takes place chiefly in Philadelphia. It begins in July, 1863, and ends after the close of the war. The hero is an army surgeon, but according to one of MitchelI's biographers this doctor is just exactly what Dr. Ifitchell was nat. 3 The theme of the novel is the defeat of the surgeon, Izra Wendell, through weakness in his ow character. Before the story begins, he has fled from the battlefield in fear for his own Iife, instead of caring for the wounded. He conceals this guilt and tries, or rather his sister attempts to make him try, to serve well in the army hospital and in the comunity. However, he is negligent and late with his duties. Finally, through carelessness in prescribing medicine, he kills the invalid son of a family who has befriended $\mathrm{him}$. Again he

2 Rebecca Washington Smith, "The Civil War and Its Aftermath in American Fiction," (unpublished Doctor's dissertation, Chicago, Illinois: Cniversity of Chicago, 1932), p. 36 .

3 Anna Robeson Burr, Weir Mitchell (New York: Duffield \& Company, 1.929), p. 114. 
is too weak to confess his guilt. Fearing that he will lose an attractive widow whom he wishes to marry, Ezra Wendell lets the family think that the boy's brother has made the mistake. Wendell pretends to be cooperating with the family in concealing the brother's mis take from the brother. One deception leads to another until when the widow finally learns the truth she does not marry Ezra. Ezra's health breaks and he goes west with his sister. The family who befriends Mzra, the Mortons, are aristocratic descendents of an old quaker family. Major Morton is wounded in the battle of Gettyskurg on Cemetery Hill and is brought to the Filbert Street Hospital at the beginning of the story. A Confederate aristocrat, a Captain Gray, is wounded in the same battle and is also brought to the hospital. Major Morton and Captain Gray happen to be out into adjoining beds. Captain Gray is fatally wounded, and in his delirium he accuses Major Morton of firing the bullet which struck him. At his death Captain Gray leaves a beautiful and charming daughter an orphan. This daughter, Hester Gray, is taken in by Bzra and his sister, and her expenses are paid by the Mortons. A cousin Henry turns up later and repays both families. After the war Hester marries Arthur Morton who had become a captain in the Inion Army. 
There is a balance of sympathy for the two sections preserved throughout the novel. Whe rever the issues cannot be completely ignored, both sides are impartially represented. A Southern girl marries a Northern man. The Northern Mortons go to Europe during the war, as the author really had done, and there they find sympatiny decidedy with the South.

Mitchell interprets the war as it affected the individual lives of certain people. There is no real discussion of sectional issueg. The theme of his novel is psychological analysis; the development of his theme is frank and realistic. Mitchell's psychological realiam is implied, however, rather than expressed. Mitchell shows the effect that Hzra's mistakes have on his Iife, but MitcheII does not teII us what Bzra thinks about or what mental and emotional struggles he goes through. This novel is different from the earlier ones, for in them, if people are defeated, it is because of their partisan beliefs, not because of their characters. Yet, In Wer Time (1884) is also different from the later fiction in this period. Writers Iike Garland, Bierce, and Crane carry psychological realisc still further by tracing the mental and emotional experiences as well as their results. This is strikingly evident in Stephen Crane's The Red Badge of 
Courage (1895), which is the most famous interpretation of the war in this period.

Stephen Crane (187I-1900) knew the war only at second-hand. 4 Mr. Max J. Herzberg gives an explanation of how Crane happened to write The Red Badge of Courage. 5

Even as a child Crane seems to have been deeply interested in the Civil War and he received from veterans unconventional opinions and from his older brother William accurate information on the strategy of the batties of Chancellorsville and Gettysburg. Later, Mr. Herzberg continues, Crane read eagerly both fiction and fact about the Civil War and made the remark concerning some articles appearing in the Century Masazine, "These articles tell a lot about what the fellows did, but not a thing about what they felt!" "Not long afterwards," Mr. Herzbere points out, "Crane wrote The Red Badge of courage, which nore

4 Crane was born on November 1, 1871, in Newark, New Jersey, the fourteenth and ninth i iving child of Reverend Jonathan Townley Crane and Mary Peck. He was born in the Methodist parsonage and named for a New Jersey ancestor who signed the Declaration of Independence. His college education stopped after $h$ is mother's death in 1890 and he became a struggling writer in New York where he was often actually hung ry and sometimes ill. Dictionary of American Biography (NTew York: Charles Scribner's Sons, 1928).

5 Max J. Herzberg, "Introduction" to Stephen Crane, The Red Badge of Courage (New York: D. Apple ton and Company, c. 1926). 
than any other war story ever published, does tell what soldiers actually feel.."

The Red Badge of Courase was well received. Mr. Herzbere says that, after Hamlin Garland and William Dean Howells had praised it warmly, Crene took it to Irving Bacheller who published it in serial form. While it was still running in this newspaper form, it was accepted by D. Appleton and Company for publication in book form and appeared on October 3,1895 . It was hailed as a masterpiece on both sides of the AtIantic and has since that date won an undisputed position as one of the most notable of all novels published in America. 6

After writing The Red Badge of Courgge (1895), Crane later became a war correspondent and traveled to many parts of the world. Although Crane had had no actual war experience when he wro te The Red Badge of Courage, 7 he

\footnotetext{
6 Herzberg, 10c. c1t.
}

7 Crane fought in the Spanish-dmerican War and was mentioned in American dispatches for gallantry under fire. Crane died on June 5, 1900, at the age of twenty-eight. He died of consumption which began when his health was undermined by the exposure and hardship he endured while on a filibustering expedition shortly before the outbreak of the Spanish-American War. During the last few years of his Iife he lived in Fngland. He married and won a large circle of friends, among the most intimate of whom was Joseph Conrad. Crane wrote novels, short stories and sketches, and verse. - Max J. Hexzberg, 10c. cit. 
later became a war correspondent, traveled to many parts of the world, and took part in actual service. When Joseph Conrad, an intimate friend of Crane's for a few years, reminded Crane that he had seen no war before he went to Greece, Crane made answer: No. But the 'Red Badge' is all right." 8 Crane's experience in warfare merely confimed wat his intuition had already told him as to how men act in battle.

The Red Badge of Courage is a narrative of only one Civil War Battle, the battle of Chancellorsville, but the narrative concerns itself with the thoughts, feelings, and actions of one young Northern soldier. The one character, Henry Fleming, carries the story, and through him Stephen Crane gives his ow interpretation of the Civil War. The causes and effects of that particular war are not treated; it could be any war. The story gives a picture of army life and of the effect of war on an individual soldier. It is a realistic picture which does not give to war any imaginary glamour. Crane's interpretation of war is revealed in a summary of the story.

The story opens with a scene in an army comp. The

8 Joseph Conrad, "Introduction" to Thomas Beer's Steohen Crane (Garden City, New York: Garden City PubIishing Company, Inc., 1927), p. 11 . 
young soldier, Henry Heming, along with other soldiers in the camp were told by a comrade that the regiment was about to go into battle. Henry had difficulty in making himself believe that he was really going to see an actual battle. He thought about $h$ is enlistment and departure from home. Only his mother's advice, warnings, and actions had somewhat spoiled his rose-colored dreams of glorious heroism. She had said "nothing whatever about returning with his shield or on it." Iy Iying on his cot the night before the rumored battle he tries to prove to himself that he will not run from the battle. A kind of panic-fear grows in his mind. He attempts to get from another soldier a confession of similar fear, and is a little reassured when he discovers that his companion has had similar thoughts. Al during the marches and during the nights preceding $h$ is first fighting fear grows in his mind -. "Will he run from the battle? Is he the only one who has such fears? Is everyone else a brave hero ${ }^{*}$ Delays strain his nerves almost to the breaking point. At the sight of the enemy he is terrified by the fear that he has not loaded $h$ is gun, but he has. He fires wildly, and then begins to work automatically. The succession of his feelings is some-

9 Stephen Crane, The Red Badxe of Courage (New York:

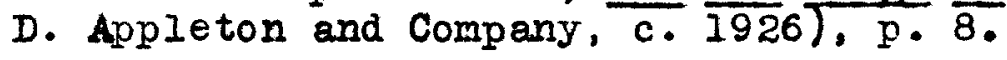


thing like this - a consciousness of teamwork, a realization of physical discomfort, an angry rage against the smoke, a wonder that relief is not sent, a recognition of the absence of herois poses among the soldiers, and then, when the soldiers mistake a lull for the end of the battle, a feeling of self-satisfaction. But the bettle is not over, and discovering that, he runs away. People who stay are fools, he tells hinself; and when he learns that the army has won, he feels ill-used. He takes refuce with the wounded and wishes that he too had "a red badge of courage." He debates whether to wish for defeat or victory for the army. Defect, it seens, would vindicate his actions. Then after having been struck on the head by a deserter, he retums to his regiment and lets them believe thet the wound has been caused by a bullet. Courage replaces is fears. He looks with scorn on others who ran away. In the next battle he fights coolly, thoughtfully, fully conscious of his acts. The lieutenant calls to $\mathrm{im}$, "By heaven, if I had ten tiousand wild cats like you I could tear the stomach outa this war in less'n a week." 10 Later Henry rescues the flag when the color bearer is wounded and is again commended. As color bearer he leads a charge. Fi10 Ibid., .168 
nally he is able to review his deeds and to decide that he is a man. 11 His rose-colored dreams of war are gone, and his panic-like fear of war is gone. He has been through the war and now he hopes for peace.

In Crane's interpretation of the war there is both psychological realism and a disillusioned attitude toward war. Note Crane's anolysis of Henry Fleming's mental state in this passage:

Presently he began to feel the effects of the war atmosphere - a blistering sweat, a sensation that his eyeballs we re about to crack like hot stones. A buming roar filled his ears.

Following this came a red rage. He developed the acute exasperation of a pestered animal, a well-meaning cow worried by dogs. He had a mad feeling against his rifle, which could only be used against one life at a time. He wished to rush forward and strangle with his fingers. He craved a power that would enable him to make a world-sweeping gesture and brush all back. His impotency appeared to $h i m$, and made his rage in to that of a driven beast.

Buried in the smoke of many $r$ ifles his anger was directed not so much against the men whom he $\mathrm{knew}$ were rushing toward $h$ im as against the swirling battle phantoms which were choking him, stuffing their smoke dow his parched throet. . . 12

A decidedly unromantic view of the war is given in the description of an incident which occurred some time between Henry Fleming's running away and $h$ is returm when he
$1 I$ Ibid., p. 232 .
12 Ibid., p. 57 . 
follows a wounded friend and tries to help him:

"Gawd! Jim Conklin!"

The tall soldier made a little comonplace smile. "Hello, Henry," he said.

The youth swayed on $h$ is legs and glared strangely. He muttered and stamered. "Oh, Jim -- oh, Jim -oh, Jim --"

The tall soldier held out his gory hand. . .

Suddenly, as the two friends marched on, the toll soldier seemed to be overcome by a terror... .

"I teII yeh what I'm 'Iraid of, Fienry. . I'm 'Praid I'II fall down - an' then yeh know - them damned artillery wagons -- they like as not'll run over me.."

The youth cried out to him hysterically: "I'II take care of yeh, Jim! .. - I swear t' Gawd I will!"

Finally the chest of the doomed soldier veyen to neave with a strained motion. It increced in violence until it $w a s$ as if an animal was within and was kicking and turbling furiously to be free.

This spectacle of gradual strangulation rade the youth writie, . .

His tall figure [the wounded soldier's] stretched itself to its full height. There was a slight rending sound. Then it began to swing forward, slow and straight, in the manner of a falling tree. A switt muscular contortion made the left shoulder strike the ground first.

The body seemed to bounce a little from the earth. "God!" said the tattered soldier [a soldier the boy was with when he met the wounded ran].

The youth had watched, spellbound, this ceremony at the place of meeting. Fis face had been tristed into 
an expression of every agony he had imagined for his friend.

- . he could see that the side looked as if it had been chewed by nolves.

The youth turned, with sudden, livid rage, toward the battlefield. He shook his fist. He seemed about to deliver a philippic.

"HelI"I3

Between the beginning of the novel and the end Henry is completely disillusioned concerning war. The progress of the disillusionment is indicated, for example, by these three passages:

The youth was in a little trance of astonishment. So they were at last going to fight. On the morrow, perhaps, there would be a battle, and he would be in it. For a time he was obliged to labor to make himself believe. He could not accept with assurance an omen that he was about to mingle in one of those great affairs of the earth.

He had, of course, dreamed of battles all his life -- of vague and bloody conflicts that had thrilled him with their sweep and fire. . . 14

- . Many of the men were making low-toned noises with their mouths, and these subdued cheers, snarls, imprecations, prayers, made a wild barbaric song that went as an undercurrent of sound, strange and chantlike with the resounding chords of the war march...

There was a singular absence of heroic poses. The men bending and surging in their haste and rage were in every impossible attitude...

13 Ibid., pp. 92-99.

14 Ibid., pp. 4-5. 
The officers, at their intervals, rearward, neglected to stand in picturesque attitudes... I5

- - as he reviewed the battle pictures he had seen, he felt quite competent to return home and make the hearts of the people glow with stories of war...

- And he imagined the constemation and the ejaculations of his mother and the young lady at the seminary as they drank his recitals. Their vague feminine formula for beloved ones doing brave deeds on the field of battle without risk of life would be destroyed. 16

The Northerm short stories resemble Crane's novel in their psychological realism and in their unromantic, disillusioned attitude toward the war. Since Crane's volume of short stories, The Iittle Regiment and Other Episodes in the American Civil War (1896), adds nothing to Crane's interpretation of the war, it will not be included in this discussion. 17

\section{Ibid., p. 59. \\ 16 Ibid., p. 153}

17 The Iittle Regiment and Other Episodes in the American civil War contains six stories. The titie story is a character sketch of two brothers who know no suitable way of expressing their affection for each other. When together they miss no opportunities to say mean, biting things to each other. The ir most civil exchange of words occurs when they are reunited after one, who has been Iisted as missing, returns to camp and after the other has moped over his lost brother for days. That greeting is a bare "hello." "Three Miraculous Soldiers" seems to say that Southerners did not really hate Northerners. A Confederate girl does all that she can to save Confederate soldiers from the Federal soldiers, but, al though to al I appearances she hates Federals, she does not wish the 
Hamlin Garland (1860- ), in one short story, gives us an unromantic and psychologically realistic interpretation of the war a.s it affected a Northern famer-soldier. "The Return of a Private" (1891)18 is the only war story which $\mathbf{M r}$. Garland wrote.

Haml in Garland, who was born on September 16, 1860, at West Salem, Wisconsin, used autobiographical material

Federals any harm. She weeps over a dead Federal soldier just as she might have been expected to do over a soldier on her own side. A soldier remarks, "War changes many things; but it doesn't change everything, thank God!" "A Hystery of Heroism" tells of a soldier who risks his life to get a bucket of water for his fellow soldiers. He seems to secure the water, give some to a dying soldier, and return to $h$ is comrades, but evidently it was mental delusion on the hero's part, caused by his desire to do something heroic, for when he reaches his comrades the bucket is empty. "An Indiana Campaign" is a humorous character sketch of an old man who assumes the burden of all the village carea because the younger men are at war. The particular incident related in this story is a ridiculous search for a neighbor's chickens which are believed to have been stolen by soldiers. "A Gray Sleeve" tells of a Federal officer who starts to search a house for Confederate soldiers because he sees a gray sleeve in the window but who instead falls in love with the girl who opens the door and does not molest her brother and grandfather. In "The Veteran" the central character is a grandfather called Mr. Fleming, possibly Henry Fleming of The Red Badge of Courage more than twenty years later. The veteran shakes his grandson's faith in his grandfather's bravery by confessing that he ran away from his first battle. An hour or so later $\mathrm{Mr}$. Fleming redeems $h$ imself and loses his life by rushing into a burning barn in an unsuccessful effort to rescue some colts.

18 Hamlin Garland, "The Return of a Private" in Main Travelled Roads (New York: Harper and Brothers, 1930). 
in this story. Incidentally his autobiographical treatment of the incident in A Son of the Middle Borderl9 is shorter and more effective than the fictional treatment in Main Travelled Roads (1890), al though the facts are the same. Wr. Garland's father was the private who returned to the Wisconsin farm. His father and mother came originally from Oxford County, Maine. Mr. Garland's literary Iife began in 1884 when he went to Boston, but he wrote about the Middle West which he knew at first hand. 20

"The Return of a Private" tells how a Northern private wearily returns to his neglected farm at the end of the war. He has more than the usual amount of work to do and far less than his nomal strength to do it with. So changed is he by the years of war that his wife and children, who have gone to $v$ is it a neighbor to break the monotony of the weary days of waiting for the private's return, do not recognize him when he passes the neighbor's house, almost dragging himself along the road.

This interpretation of the war certainly omits all trace of the North's "glorious" victory.

19 HamI in Garland, A Son of the Middle Border (New York: The Macmillan Company, 1917).

20 Biographical facts from: Dilly Tante, editor, Iiving Authors (New York: The H. W. Wilson Company, 193I). 
A still more bitter interpretation of the war is found in Tales of Soldiers and Civilians (1891) and Can Such Things Be? (1893), two collections of short stories by Ambrose Bierce (1842-1914). Bierce wrote his war stories long after the war, but he had first-hend experience to record for he served in the Northern army throughout the entire period of the war. 21 In 1861, Bierce, who was

21 Silas Weir Mitchell and Ambrose Bierce are the only two Northern authors in this period who did have first hand war experience. A full account of Ambrose Bierce's Civil War experiences may be found in Napier Wilt's article "Ambrose Bierce and the Civil War." The purpose of Mr. Wilt's article is threefold: (I) to trace Bierce's actual war experiences, (2) to examine his autobiographical sketches in the light of the official records and of histories and memoirs of related events, and (3) to determine how much Bierce wrote from memory and how much he took from the writings of others. Mr. Wilt traces the moves of the Ninth Indiana Infantry of which Bierce was a nember, lists the battles in which Bierce fought (among them Philippi, Shiloh, Perryville, and Stone River), notes the time that Bierce was away from the regiment in a hospital, and points out that Bierce served as topographical engineer. At the end of the war, $\mathbf{M r}$. Wilt has discovered, Bierce should have been made "Brevet Captain" instead of "Brevet Major." It was a clerical mistake. In 1867 Congress authorized the War Department to promote all men who had distinguished themselves in the service to the rank above that they held at the close of the war. About 6,200 were honored, and the clerk made a mistake in writing "Brevet Major" beside Bierce's name. With regard to the second and third of $\mathrm{Mr}$. Wilt's aims, Mr. Wilt found that Bierce used both his memory and the writings of others and that his use of the first personal pronoun is not evidence that Bierce himself did the thing related. -Anerican Iiterature, $1: 260-285$. 
born in Meiggs County, Ohio, in 1842, the youngest child of poor and obscure farming folk, was nineteen years old and was employed as a printer in Warsaw, Indiana. He volunteered as a private and became a member of the Ninth Indiana Infantry and served with distinction through many of the most difficult campaiens of the western armies. Twice he risked his Iife rescuing wounded companions; and twice he himself was wounded, once slightly in the heel, and once, at Kenesaw Mountain, seriously, in the head. The war ended, he was brevetted Major for distinguished services by especial act of Congress. He then became custodian of "captured and abandoned" property at Selma, Alabama, resigning in 1866 to accompany General W. B. Hazen on an inspection tour of the northwestern arry posts.

Although Tales of Soldiers and Cirilians (1891) was Bierce's first published collection of war stories, Bierce was by no means a new and unknow writer in 1891. When his army duties were completed, he joined his brother Albert in San Francisco and, while working with him in the Mint, contributed paragraphs to several weeklies. In a period of very bitter personal joumalism his caustic wit and courage brought him recognition and the editorship of one of the weeklies, the News Ietter. During the rest of 
his Iife he was employed in journalistic work in CaIifornia, England and Washington, D. C. With only one brief absence he lived in Califoinia from 1876, when he returned from Iondon, until 1896, when he went to Washington. It was during these years that he wrote his Civil War stories and did practically all the work on which his fame was to rest. In 1913 Bierce vent to Mexico on the staff of the insureent Villa and is supposed to have been killed. He had expressed a desire to be slain in war. There are several stories about his death, none of which has been proved with certainty.

Bierce gave the American Civil War Iiterary interpretation because it provided him with grim and extraordinary events he liked to record. A satirist, he satirizes war, rather than man, in his stories. Accurate, psychological analysis, or foychological realism, characterizes his work. So tart was Bierce's realism that Tales of Soldiers and Civilians was not readily accepted by either publishers or readers. 22

The themes of the fifteen war stories in Tales of Soldiers and Civilians are tragedies experienced by indi-

\footnotetext{
Biographical facts from Dictionary of American Biography and from C. Hartley Grattan, Bitter Bierce (Garden City, New York: Doubleday, Doran and Co., Inc., 1929).
} 
vidual Federal soldiers. These tragedies end in the death of the central character or in the death of his loved ones or in the deaths of both. In each case the cause of the tracedy is outside the hero himself. The heroes, with the exception of a deaf-mute child, are strong men overcome by fate. The settings of the stories include Virginia, Alabama, Georgie, and Tennessee. The characters are mostly Federal soldiers.

Bierce wrote twenty-one war stories in all, the fifteen already mentioned and six in Can Such Things Be?. Three stories use the divided family theme. Soldiers in the Federal army doing their duty as they see it, fire on close relatives in the Confederate Amy. 23 Five stories are psychological analyses of certain mental states: a soldier's thoughts before his execution, 24 the effects of fear, 25 and a captain's reaction to his first battle.26 One story presents a realistic picture of the wounded soldiers just after a battle, a picture emphasized by beine

23 "A Horseman in the Sky," "The Affeir at Coulter's Notch," and "The Mocking-Bird."

24 "An Occurrence at OwI Creek Bridge."

25 "One of the Missing," "Parker Addison, Philosopher," and "Georee Thruston."

26 "One Officer, one Man." 
presented from a deaf-mute child's point of view. ${ }^{27}$ one story seems to say that war has no respect and no reward for even the greatest courace. A "son of the gods" was killed, just as any other soldier might have been, in securing necessary information for $\mathrm{k}$ is army. 28 The tragedy in two stories was caused by woman's weakness or stupidity -- a girl, who did not want her sweetheart to crouch behind a tree in a battle, 29 and an unfaithful wife. 30 Both sent fine men to their death. The tragedies of three stories were caused by freak twists which fate gave to relationships among soldiers, relationships involving such common emotions as devoted love between friends, jealousy, anger, and resentment. 31 These are the fifteen stories of Tales of Soldiers and Civilians. The six in Can Such Things Be? are not as tragic. They usually end in the death of the hero, it is true, but the cause is in the hero's ow mental state or in supernatural or unexplained agents. These stories are more weird than

\footnotetext{
27 "Chickamauga."

28 "A Son of the Gods."

29 "Killed at Resaca."

30 "An Affair of Outpos ts."

31 "The Coup de Grace," "The Story of a Conscience," and "One Kind of Officer."
} 
tragic or horrible. For example, in "A Tough Tussle" a second-lieutenant is killed by a dead Confederate soldier. Alone at night in a forest, the Federal officer becomes so convinced that the corpse has moved that he fights with it and is himself found dead with his own sword through his breast.

Bierce interprets the war from a disillusioned, unromantic, bitter point of view. A quotation from "An Affair of Outposts" states definitely a civilian's disilIusionment. The civilian in the story is a governor of a Northem state:

In all this was none of the pomp of war -. no hint of glory. Even in his distress and peril the helpless civilian could not forbear to contrast it with the gorgeous parades and reviews held in honor of himself -- with the brilliant uniforms, the music, the banners, and the marching. It was an ugly and sickening business: to all that was artistic in his nature, revolting, brutal, in bad taste.

"Tgh!" he grunted, shuddering -- "this is beastly! Where is the charm of it all? Where are the elevated sentiments, the devotion, the heroism, the.."

From a point somewhere near, in the direction of the pursuing enemy, ro se the clear, deliberate singsong of Captain Amisted. ing."

"Stead-y, men -- stead-y. Halt! Commence fir-

The rattle of fewer than a score of rifleg could be distinguished through the general uproar, and that penetrating falsetto:

"Cease fir-ing! In re-treat -- maarch!"32 
Let us analyze one story more fully. Any one would do, but "Chickamauga" contains particularly unpleasant realism. In "Chickamauga" a deaf-mute child, armed with his wooden sword, wanders away from home and is lost in a forest. Finally, worn out with wandering, he falls asleep. On awaking he sees hundreds of men creeping, crawling, staggering toward the creek. Their faces, streaked and spotted with red, make him think of circus clows. Somehow, confusing their movements with his father's negroes' movements when playing horse with $h$ im, the child mounts and sits astride one man:

- Who sank to his breast, recovered, flung the small boy fiercely to the ground... . then turmed upon him a face that lacked a lower jaw -. from the upper teeth to the throat was a great red gap fringed with hanging shreds of flesh and splinters of bone. -. The man rose to his knees, the child to his feet. The man shook his fist at the child; the child, terrified at last, $r a n$ to a tree near by, got upon the farther side of $i t$ and took a more serious $\nabla$ iew of the situation.. .33

Though the child does not realize it, a battle was fought, almost beside him, while he slept. Now he notices a light across the creek. Cros sine the stream on stones, he goes toward it.

\footnotetext{
32 Ambro se Bierce, In the Midst of Iife (New York: Futnam, 1927), pp. 157-158.
}

33 Ibid., p. 52 . 
Shifting his position, his eyes fell upon some outbuildings which had an oddly familiar appearance, as if he had dreamed of them. He stood considering them with wonder when suddenly the entire plantation, with its inclosing forest seemed to turn as if upon a pivot. His little world smung half round; the points of the compass were reversed. He recognized the blazing building as his ow home.

For a moment he stood stupefied by the power of the revelation, then ran with stumbling feet, making a half circuit of the ruin. There, conspicuous in the lieht of the conflagration, lay the dead body of a woman -- the white face turned upward, the hands thrown out and clutched full of grass, the clothing deranged, the Iong dark hair in tangles and full of clotted blood. The greater part of the forehead was torn away, and from the jageed hole the brain protruded, overflowing the temple, a frothy mass of gray, crowned with clusters of crimson bubbles -- the work of a sheli.

The child moved his little hands, making wild, uncertain gestures. He uttered a series of inarticulate and indescribable cries -- something between the chattering of an ape and the gobbling sound of a turkey -- a startling, soulless, unholy sound, the language of a devil. The child was a deaf-mute.

Then he stood motionless, with quivering lips, looking down upon the wreck. 34

In contrast to Bierce's use of psychological realism in presenting horrible incidents, we have Harold Frederic's use of it in telling stories which, at least, end pleasantly. Bierce's interpretations of the Civil War were published in 1891 and 1893. Harold Frederic published his volumes of short stories dealing with the war in 1893,

$$
34 \text { Ibid., pp. 56-57. }
$$


1894, and 1898. Being fourteen years younger than Bierce, Frederic had no actual battleground experience to record. Only two of his seven stories, "A Day in the Wildemess" and "The Deserter," deal with army life and fighting. The other five interpret the war as it was experienced by stay-at-homes in New York State. Nlthough very young, Frederic knew that iffe at first hand.

Harold Frederic (1856-1898) was born in Ttica, New York, on August 19, 1898, of Dutch, French, and New England ancestry. His ancestors were mong the early settlers of the Mohawk Valley. When Harold Frederic was eighteen months old, $h$ is father was killed in a railroad accident. To support her family Mrs. Frederic kept a dairy. As soon as Harold was old enough, he got up at four o'clock in the moming and delivered milk before school. The children at school made fun of his milk stained clothes. Later he jecame a retoucher of photographic negatives, but the eye-strain vas too great. One of his stories, "Marsena," has a photographer as the central character. At the age of twenty he became a reporter on the Itica Observer. Fight years later, in 1884, he became the London correspondent of the New York Times and spent the rest of $h_{1}$ is short Iife in Europe. He died in 1898. His Civil War s tories must have been written in 
Europe, but they were published in New York. 35

In 1893 Frederic published The Copperhead and Other Stories of the North during the Civil War. In 1894 he published Marsena and other Stories of the Wartime. All these stories were brought together in 1897, and published by C. Scribner's Sons under the title of In the 'Sixties. The stories are: "The Copperhead," Mrarsena," "The War Widow, "The Eve of the Fourth," and "My Aunt Susan." These stories are psychological studies of emotional problems of stay-at-homes. The underlying causes of the situations Frederic describes are, in contrast to Bierce's stories, in the characters of the people in the stories; but the abnomal tension of wartimes exaggerated each person's selfishness, narrowness, enviousness, or kindness in to violent loves and hatreds. The characters in all the stories belong to the farmer class, the working class, or the well-to-do village class of New York State. Harold Frederic wrote two other Civil War stories which concern soldiers, "The Deserter" and "A Day in the Wilderness." These two stories were published in 1898 in a volume called The Deserter and Other Stories. I shall analyze "The Copperhead," because it is the most serious interpretation

\footnotetext{
35 Biographical facts from The Dictionary of American Biography.
} 
of the war among his earlier stories, and these two later stories, because they are better interpretations than the earlier ones.

"The Copperhead" is a "sketch of the animosities and violent revenges that characterized the life of a stay-athome people during the Civil War."36 Abner Beech, the central character in "The Copperhead," has read more books than any other farmer in the neighborhood and $c$ an discuss them, but he knows absolutely nothing about the wisdom of keeping the good will of his neighbors. Beginning with lightning rods and ending with hatred of abolitionists, he slowly lets one thing after enother cut himself and his family off from all relations and dealings with his neighbors. His son, however, regardless of his father's opinions, falls in love with the daughter of Abner's chief rival and enlists in the Inion Army. Abner lets the bitter feeling against himself increase still more. Finally, when the election comes and the Abolitionists are beaten in this Congressional district, feeling runs so high that a mob of neighbors come to toment Abner and end by burning $h$ is house to the ground. The next moming, through the efforts of his son's sweetheart, peace and good will

\footnotetext{
36 Irnest Albert Baker, Guide to Historical Fiction (New York: The Macmillan Company, 1904).
} 
are re-established between Abner and the neighborhood.

The theme of "The Deserter" is that it is not always a disgrace to be a deserter. Mose Wipple, the deserter, saves his father's life by coming home. He asks for a furlough, but is refused by a Dutchman in authority who has a grudge against him. Mose went to war in July, 1863 , es a substitute for Elisha Teachout, 2 rheumatic, grouchy, stingy owner of a dairy farm. Hose and his father, Asa, owe Teachout something over $\$ 300$ in accrued interest on mortgages which he holds, and for that reason Mose went as his substitute. Teachout promised to look after Asa, but he does not do it. Mose comes home the last week in 1863 and finds his father almost dead from starvation. When Asa realizes that Mose has deserted, he strongly disapproves and urges Mose to return. He thinks "deserter" the meanest word that $c$ an be applied to a man. He stops urging Mose to return, however, when he learns that the penalty for desertion is death. The deputy marshal who is sent for Mose feel that Mose was justified in coming home and he lets Mose escape. Later Mose starts back, and the deputy marshal takes him to his father instead of to war. In the spring of 1864 Teachout forecloses, and Asa and Mose go to the woods to Iive. The story Ieaves them there contented. 
The theme of "A Day in the WiIdermess" is jus $t$ what the title states. It telis the experiences of a drumer boy on the second day of the Battle of the Wilderners. He talks with a Geman flute player, fights with a bounty jumper who has quite a collection of stolen articles, and finally rescues from a forest fire an officer who proves to be his cousin. The following quotation gives an idea of the impression of war which the story creates:

It was the morming of the second day of the Battle of the Wilderness. The men of Boyce's brigade knew only vaguely, by hearsay, of what had happened on that terrible yesterday. They themselves, forming the rear-guard of the great army, had been nearly the last to cross the Rapidan on the swinging ponto on bridge of Germania Ford. They had had a night's forced march; a two hours' nap in the open starlight; a hasty bite of rations at half-past-three in the morning, and now this pIunge in the chiIIy twilight of sunrise down into the unknown. 37

Like all other authors who interpret the war in this period Frederic shows how individuals were affected. There is psychological realism in all his stories. The Deserter" shows a marked disillusionment about war when the Iife of a boy's father is placed above the cause he was fighting for. Among the Southern stories are those of Thomas NeIson Page and George Cary Eggleston. There are no thoroughly disillusioned, unromantic pictures of war

37 Harold Frederic, The Deserter and other Stories (Boston: Iothrop Publishing Compeny, 1898), p. 149 . 
Iike Crane's and Bierce's, probably because the South was not so thoroughly disillusioned concerming the war as the North was over its "victory." Psychological realism is present in the interpretations of Page and Eggleston, al though it is not so prominent as it is in the interpretations written by Northemers. There is no great distinction between Frederic's stories and the Southem interpretations by Page and Eggleston, but between Bierce's stories and the Southern stories there is a wide gap. Page and Eggleston interpret the war mildly in their close-up views of the wartine experiences of various people at given times.

Thomas Nelson Page (1853-1922), who was born on a Virginia plantation, the son of a distinguished family, heard many stories about the golden times "before the war," and he will be remembered as a writer of local color stories which exploited the glories of the antebellum South. 38 However, in the 1890's when the war was being interpreted as individual human experience, with the interest in the individual, Page published The Burial of the Guns and other Stories (1894), a volume containing three stories wich interpret the war in the spirit of the time. 38 Biographical focts from Dictionary of American
Biography. 38 Biographical fects from Dictionary of American
Biography. 
The title story tells of the love of several Confederate soldiers for six guns which they have named Matthew, Mark, Iuke, John, The Eagle, and The Cat. At the end of the war, in the midst of their grief over the South's final surrender, the soldiers hold a ceremony, "the burial of the guns," in which they roll the guns over a cliff.

"The Gray Jacket of 'No. 4"' is another war story. Mo. 4," a war veteran and a hopeless drunkard, had been a brave soldier, and he prizes his Eray jacket above everything elve. Finally, however, he paws it for the drink that kills him. A friend redeems the jacket and has "llo. 4" buried in it.

The third war story is called "Iittle Derby." Iittle Darby, a Confederate soldier, and his sweetheart prevent the Federal soldiers from raiding their community, a community of poor whites, by burning a bridge.

What interpretation of the war is there is these three stories? There is no bittemess toward anyone. The stories simply tell us what the war meant to certain individuals at given times. The Confederate soldiers at the end of the war sentimentally loved the defeated guns which had fought so well for them. After the war "No. 4" cherished his gray jacket because it revinded him of the war- 
times when he had been a better man. Iittle Darby and his sweetheart had a chance to do an heroic deed because of the war. In all three stories Page interprets the war sentimentally, just as he interpreted the old south in his local color tales. The individual experiences which he records are pleasant.

A fuller interoretation of the war from a Southerner's point of view is found in Southern Soldier Stories (1898) by George Cary Iggleston. Eggleston's 251-page volume contains forty-seven very short stories.

Page bases his interpretation of the war chiefly on hearsay, but Eggleston had first-hand experience to record. Borm on November 26, 1839, Eggleston was twenty-one years oId when the war began, and, al though born in Vevay, Indiana, he was a Virginia gentleman in 1861. At the age of seventeen he had inherited his family's plantation in Amelia County, Virginia, and he had been astonished and chamed by the aristocratic, genial, and leisurely life that he entered. In the few years between that time and the outbreak of the war he studied law at Richmond College and made friends with the Richmond literary group, especialIy John Esten Cooke. During the war Eggleston served in various capacities. In 1861, with many other gentlemen horsemen, he saw service in Northern Virginia, in the 
First Virginia Cavalry, first under Col. J. E. B. Stuart and later under Gen. Fitzhugh Lee. In the autumn he was transferred to the field artillery on the South Carolina coast, but in 1863 he was back north in Iongstreet's artillery. That winter, as sergeant major of his battery doing provost guard duty under General Iindsay Walker, he was detailed because of his legal training to defend the worst offenders before courts martial. In 1864 his battery served as sharpshooters through the bloody siege of Petersburg; and Fggleston, with his brother Joseph as second in comand, was in charge of a mortar fort. Southem Soldiex Stories (1898) is dedicated to this brother:

I dedicate this book to the 'Joe' so often inentioned in these $s$ tories. He was my loved comrade in arns, and a sharer in all my war experiences. He is now Dr. Joseph W. Eggleston of Richmond, Virginia."

With all his first-hand war experience, however, Eggleston wrote only the one volume of war stories, and that did not eppear until 1898. In the intervening years Eggleston worked in IIIinois, married, practiced law in Mississippi, and for twenty years did newspaper and editorial work in New York. 39 When Eggles ton wrote Southem stories, he, like Page, wrote mostly about pre-war Virginia.

\section{Biographical facts are from the Dictionary of} American Biography. 
Southern Soldier Stories (1898), Eggleston's one volume of war stories, relates strange incidents which occurred among the soldiers during the war. The settings of the stories are usually in South Carolina and the leader most frequently mentioned is stuart, who is pictured as an enthusiastic, sympathetic, and much loved officer. There are forty-seven stories. Approximately one-third of them are merely pleasant stories telling such things as how battles were won by happy accident, one-third honor bravery and good soldiership, and the remaining third deal with various aspects of the war including certain interesting "characters" met in camp life, brave women, and so on. The stories are not arranged in this fashion. There is no particular pattern in their organization except that those dealing more or less with the early years of the war come first and those with the end of the war, last. Many of the stories could have happened just as well at either time.

A brief statement of the plots of a few of the stories will show Eggleston's interpretation of the war. One story expresses admiration for courageous and intelligent soldiers. Joe's disrespectful conduct toward a superior is overlooked because of his bravery and fighting skill. The next $s$ tory is a $d$ iscussion of whether or not any sol- 
dier is without fear, and the question is answered in the negative. Another story uses the divided family theme. Twin brothers on opposite sides meet in battle and drop their swords, and Eggleston observes that "blood is thicker than water." It is interesting to note that in Bierce's stories duty is stronger than love in such cases. Another story shows how great was one man's devotion to the Southem cause. The man loses six sons in the war and when he himself receives his death wound, he says that his girls will have to fight. To him losing his sons and dying is not hard, but being thus prevented from serving the South is bad luck. Some of the stories, "William," for example, are chiefly character sketches. William is a humorous character who always refers to himself by name. One day he stops a quarrel in this way:

Then pulling our a pocket-book, which was fat with humorous clippings, but which both men knew to contain nothing more valuable, he caressed it lovingly and said: "Before you proceed, William wants to bet one hundred-dollars to ten with one or both of you ... that neither of you two sublimated idiots can William a reasonable excuse for this quarrel."

This story has nothing to do with the is sues of the war. Equally far removed from a historical view of the war is one which tells how the soldiers found an orphaned child

40 G. C. Eggleston, Southem Soldier Stories (New York: The Macmillan Company, 1898), p. 27. 
and enjoyed making clothes for her. Still another s tory telis how a girl disguises herself as a soldier and kills twenty-one Federals to avenge the death of her twenty-oneyear-oId lover.

A particularly interesting story is "Notes on Cold Harbor," which was written for the Century publication, Battles and Ieaders of the Civil War (1884-1887). In this story Eggleston deals humorously with the South's "logic" and stresses the importance of the quality of the rolunteers in both armies. The story begins, "I always think of our arrival at CoId Harbor as marking a new phase of the war. $n 41$ The Southem soldiers had finally gotten over their astonishment and disappointment at the "illogical" conduct of General Grant, who did not retreat and otherwise conduct his campaign in a logical way. However, Eggleston adds that their astonishment was characteristic of the southerm attitude toward the war.

- The Southern folk were always debaters, loving $\log i c$, and taking off their hats to a syliogism.

They had never been able to understand how any reasonable mind could doubt the right of secession, or fail to see the unlawfulness and iniquity of coercion, and they were in a chronic state of astonished incredulity, as the war began, that the North could indeed be about to wage a war that was manifestly forbidden by unimpeachable logic. 42

41 Ibid., p. 291. 
Then Bggleston speaks of the capacity for cheerful endurance which the soldiers showed. He says:

With mercenary troops or regulars the resistance that Lee was able to offer to Grant's tremendous pressure would have been impossible in such circumstances. The starvation and the excessive marching would have destroyed the morale of troops held together only by discipline. No historical criticism of our Civil War can be otherwise than misleading if it omits to give a prominent place, as a factor, to the character of the volunteers on both sides, who, in acquiring the steadiness and order of regulars, never lost their personal interest in the contest, or their personal pride of manhood as a sustaining force under trying conditions. 43

Eggleston gives literary interpretation to the war by presenting a series of close-up views which are pleasant in tone and which present the best side of the people affected.

To sum up this entire period: Between 1880 and 1899 psychological realism characterizes the fictional interpretations of the American Civil War. It reaches its height in The Red Badge of Courage (1895). The autiors are interested in the war as individual human, mental, and emotional experience aside from all sectional issues.

\footnotetext{
42 Ibid., pp. 193-194.

43 Ibid., Dp. 198-199.
} 
Another characteristic of this period is the unromantic, disillusioned attitude toward the war which reaches its height in Bierce's stories. Nowhere in the fiction of this period is the war itself regarded either as a glorious cause to fight for, as A. J. F. Wilson regarded it in 1864, or as an accomplishment, as DeForest pictured it in 1867. Between 1880 and 1899 the fiction dealing with the American Civil War interprets the war with psychological realism, and without any partisanship, as many different kinds of human experience.

The reason for this shift in the kind of interest authors had in the war -- a shift from a partisan interest in the sectional and political issues of the war to an artistic or literary interest in war itself and in a ps ychological analysis of war experience -- may be found in contemporary literary trends and in the state of the American mind regarding the war. The literary trend was toward a subjective realism and the American mind, especially in the North, had been disillusioned concerning the war.

But the disillusionment did not last. At the end of this period the Spanish-American War aroused a spirit of patriotism in America together with dreams of nationalism and imperialism. There were pride in the Nation's 
past and great hopes for her future. Historical romances interpreted the Civil War as an important step in the Nation's progress. Their interpretations are the subject of the next chapter.

It is interesting to note that three of the rost important anthors of the Civil War period did not interpret the war in fiction.

Mark Twain (1835-1910), it seems, deliberately avoided any serious treatment of the Civil War. At the beginning of the war he enlisted in the Confederate arry, but he withdrew two weeks later and went to California where he stayed throughout the war. He tells the story of his brief service in "The Private History of a Campaign that Failed." Al though Mark Twa in knew the South, he never gave it his allegiance, and eventually Grant became his greatest hero and his attitude toward slavery became as passionately Northern at that of Hrs. Stowe. In Pudd'nhead Hilson (1894) Mark Twain deals with slavery, and in the Gilded Age (1873) he deals with the period from 1850 to 1873 and subordinates the war to a portion of one chapter. In neither does he deal directly with the war or 
probe deeply into its effects. In speeches he dealt with the war as a subject for burlesque. 44

Will iam Dean Howells $(1837-1920)$ intended to write a Civil War novel. He was an abolitionist and was extremeIy interested in the outcome of the conflict, al though he went to Venice shortly after the conflict began and was there throughout the four years of the struggle. Before his departure for Venice, he thought of writing a novel with its scene in Columbus, Ohio, at the time of the first volunteering. He did write two poems of minor importance, but he never wrote the novel. Miss Smith explains the fact in this way:

- - If he never carried out his plans to use it, it was chiefly that he adopted a literary creed which was not congenial with it.

- Although he temperamentally and theoretically disliked war, his avoidance of the theme and his unfriendly attitude toward the historical romances about it were motivated not primarily by temperament but by his literary doctrine of realism which stressed the average, the commonplace, the "more smiling aspects of life," and therefore had little affinity with the events of 1861 to 1876 in American 1 ife.45

Henry James (1843-1916) used the war theme in sev-

44 These facts on Mark Twain may be found in Miss Smith's thesis and in Stuart P. She rman, "Mark Twain," The Cambridge History of American Literature, III, 3 . 
eral short stories which were published in the Atlantic. They are of minor importance in his writings, but they show that he had no interest in the traditional historical novel. His critical theories, as in the case of Howells, pointed him away from an interest in war or reconstruction. Miss Smith says:

- he was for a time deeply interested in the effects of the civil War on its soldiers and their renewed contacts with nomal life. The disillusionments of the nation from 1865 to 1876 must have had no small part in sending him elsewhere to seek a more gracious civilization. 46

46 Smith, op. cit., p. 25. 
CHAPTER III

POLITICAI: KATIONAIISM AND HCMANITARIANISM $1900-1919$ 
CHAPTER III

POIITICAI : INATIONAIISM AND HLISAMITARIANISM $1900-1919$

Ify entire list of Civil War fiction written during the years between 1900 and 1919 includes eighty-one items. Of these, forty-two are love romances and stories of $\mathrm{mili-}$ tary and naval adventure, ten are juvenile novels, ten center on the post-war period, and ten make the war secondary to some other theme. The remaining $n$ ine novels seriously interpret the American Civil War as individual or national experience. The Northern novels are: The Crisis (1901) by Winston Churchill, They That Took the Sword (1901) by Nathaniel Stephenson, and The Financier (1912) by Theodore Dreiser. The Southern novels include: The Battleground (1902) by Elien Glasgow, Manassas (1904) by Toton Sinclair, The WeIding (1907) by Emily Iafayette McLaws, The Warrens of Virginia (1908), a novel by Georee Cary Eggleston based on a play by DeMille, and The Long RolI (1911) and Cease Firing (1912), two novels by Mary Johnston.

These fictional interpretations show two trends, first, one toward a national, Cnion sentiment, and second$1 y$, one toward international, humanitarian sentiment. I 
have called the second trend international because the pacifist movement was being carried on in Europe as well as in America. The characteristics of the first group, which includes the six novels witten in the first decade of the century, are:

1. The themes relate to the fate of the country.

2. The plots are directly related to the conflict between the North and the South.

3. Historical characters are introduced.

4. Fictional characters are representative of attitudes and social classes characteristic of various sections of the country.

5. Actual varfare is described as realistically as it was in the 'nineties.

In all this fiction there is an atterpt to record what had lasting significance in our national life. As for the historical interpretation itgelf, there seems to have been no side except Lincoln's in the early years of the twentieth century. The general conclusion is that the war created a perfect and united nation by abolishing slavery. The chief distinction between the Northern and the Southerm fiction is in their explanations of the cause of the war. The Northern fiction makes slavery the thing the North was fighting against; the Southern fiction states, parenthetically, that many Southern planters did not love slavery and makea the South's love for their section the 
cause of their fighting. In glorying in the new nation, the Southerm novels are only a little less strong than the Northem. Strange as it seems the Southern novels are more nume rous.

The characteristics of the humanitarian novels, The Long RoII (1911) and Cease Firing (1912), are similar to those of the novels which praise the new Union, but there is one important difference. Mary Johns ton's novels describe one wartime scene after another with the emphasis on the suffering of individuals. The purpose of these novels is not to glory in a new and perfect Inion, but to forvard the pacifist movement which was intermational in its scope. A significant European contribution to this movement was Ground Ams! (1892), an anti-war novel by an Austrian woman, Baroness Bertha von Suttner.1

The Financier (1912), a novel by Theodore Dreiser, who is a Northerner, covers a much longer period than that covered by the war, but it makes a contribution to Civil War interpretations too important to be omitted here. Dreiser was interested in describing the type of man that the Civil War allowed to rise. This type of man, the individualist and capitalist, is treated with scorn as

I Bertha von Suttner, Ground Ams! (Chicago: A. C. McClurg and Company, 1892). Translated from the German by Alice Asbury Abbott. 
Mliphalet Hopper in The Crisis (1901), with faithful fidelity to facts as Cowperwood in The Financier (1912), 2 with definite recognition of his ability as Rhett Butler in Gone with the Wind (1936), and with a hero's glory as George Posey in The Fathers (I938).

The Crisis (1901) by Winston Churchill is a good Northern example of the historical romances which are charecterized by national, imperialistic, Cnion sentiment. The scene is laid chiefly in St. Iouis where ifr. Churchill was born on November 10, 1871. After completing his schooling at Smith Academy in St. Louis and at Annapolis where he received his degree in 1394, $\mathrm{Mr}$. Churchill was financially able to devote himself to fiction writing and he did so. American his tory was his favorite subject at schod, and he wrote several novels dealing with American historical events. 3

The theme of The Crisis is American his tory during the critical years imediately before and during the Civil

2 Dreiser based his novel on a well-documented study of the wartime magnate, Yerkes, who gave Yerkes Observatory to the Iniversity of Chicago.

3 Biographical facts from: Dilly Tante, editor, Iiving Authors (New York: The H. W. Wilson Company, 1931). 
War and ending with Iincoln's death. It is not only political history, but social and economic, as well. Mr. Churchill tried to present everything belonging to those critical years which was of significance in the development of our American nation.

Mr. Churchill chose St. Iouis for the principal scene of his story because it was a meeting place for all the essential elements of the conflict and because it contained those that survived to form the new nation. In an "Afterword" Mr. Churchill says:

The author has chosen St. Louis for the principal scene of this story for many reasons. Grant and Sherman were living there before the Civil War, and Abraham Iincoln was an unknown lawyer in the neighboring state of Illinois. It has been one of the aims of this book to show the remarkable contrasts in the lives of these great men who came out of the West. This old city of St. Louis.. . became the principal meeting place of two great streams of emigration which had been separated, more or less, since Cromwell's day. - . When this great country of ours began to develop, the streams moved westward; one over what became the plain states of Ohio and Indiana and IIIinois, and the o the $x$ across the Blue Ridge Mountains into Kentucky and Tennessee. They mixed along the Iine of the Ohio River. They met at St. Iouis, and, farther west, in Kansas.

Nor can the German element in St. Louis be ignored. The part played by this people in the Civil Viar is a matter of history. ...

The characters are representative of the many types of people to be found in St. Louis. The heroine is VirEinia Carvel, the daughter of Colonel Carvel, a Southern 
aristocrat. They are living at the time of the $s$ tory in a handsome St. Louis residence, and Colonel Carvel is the owner of Carvel and Company, Wholesale Dry Goods Store. Closely connected with Virginia and her father are relatives, slaves, employees, and business friends and acquaintances. There is the Southern Clarence Colfax, VirEinia's daring and adventurous cousin and fiance.. The re is Eliphalet Hopper, twenty-seven years old when the story begins, an ambitious, unscrupulous man from Massachusetts who was employed by Colonel Carvel on the day of his arrival in $s t$. Louis and who becones a capitalist, nakes money out of the war, and has no sympathy with either North or South. There is Judge Silas Wipple, a lawyer and Colonel Carvel's best friend, who is violently opposed to Colonel Carvel in his anti-slavery sentiments and in his political opinions. Judge Whipple is a Northern sympathizer and a believer in the preservation of the Inion. Then, there is a Mississippi River boat captain, Captain Iige Brent, who has been helped financially by Colonel Carvel, who is accepted as a family friend, and who delivers shipments of goods to Colonel Carvel's store. In the war he takes the tnion side. So much for Virginia Carvel, the southern he roine, and her associates. The hero is Stephen Brice, a young college man from Boston, who, with 
his mother, has come to St. Iouis to begin a law career, in the office of Judge Wipple, a friend of his father. Because of the death of his father and the loss of their fortune, Stephen Brice is not able to continue his education in law school. He and his mother represent the Boston aristocracy. In Silas Whipple's office Stephen met Carl Richter, a representative of the university-bred German revolutionists who emigrated after 148 . In addition to the se fictional characters there are historical figures -- LincoIn, Grant, Sherman, and others. The picture $\mathrm{Mr}$. Churchill gives of Lincoln is in harmony with the Iincoln myth, which appeared as early as 1867 in Beecher's Norwood.

The story is divided into three books. The first book introduces all the characters in the old life before the war and ends with a party in celebration of Virginia's eighteenth birthday. The reader realizes that although Virginia is engaged to Clarence Colfax and although Eliphalet fiopper has hopes of winning her by accumulating a fortune, Stephen Brice will be the winner in the end. It is important to remember that these characters are symbols of social clesses. What happens to them is indicative of Churchili's interpretation of the events of the period. Here we have a Northern aristocrat winning a 
Southem aristocratic bride (who $f$ inally deciaes that the North is right) over a Bouthern aristocrat and a Northern middle class capitalist. The strong feeling over slavery is indicated in Book I by Colonel Carvel's and Judge Whipple's conversations. Colonel Carvel believes slavery to be a divine institution and indispensable to the South, and he fears that the Horth will overwhelm the slave states. Judge Whipple holds abolitionist views. I will quote from their conversations:

"No, Wipple," said the Colonel, "when God washed off this wicked earth, and started new, He saw fit to put the sons of Ham in subjection. . . Abuses can't be helped in any system, sir, though we are bettering them. . . ."

"A divine institution!" he shouted. "A black curse! Because the world has been a wicked place of oppression since Noah's day, is that any reason why it should so continue until the day of Judgment?"

"Now, see here, Whipple," said he. "If we had any guarantee that you would let us alone vihere we are, to manage our slaves and to cultivate our plantations, there wouldn't be any trouble. But the country keeps on growing and growing, and you're not content with half. You want everything, -- all the new states must abolish slavery. And after a while you will overwhelm us, and ruin us, and make us paupers. Do you wonder that we contend for our rights, tooth and nail? They are our rights." 4

Book II is concerned almost entirely with characterizing

4 Winston Churchill, The Crisis (New York: The Macmilian Company, 1901), p. 77 . 
Iincoln and with getting the war well started. It begins with the Geman's, Carl Richter's, devotion to liberty, a background for making Ame rican liberty some thing of inestimable value. In telling his story Carl Richter says, in part :

"We lost [our liberty], as I told you, hecause we knew not how to hold what we had gained. I left Germany hop ing to make a home here for my poor father. How sad his face as he kissed me farewe 11 ! And he said to me: 'Carl if ever your new Vaterland, the good Republic, be in dancer sacrifice all. I have spent my years in bondage, and I say to you that life without liberty is not worth the living.' Three months I was gone, and he was dead without that for which he had striven so bravely. He never knew from one day to the other when he would have to embrace me, all he owned, and march away to prison, because he was a patriot." Richter's voice had fallen low, but now he raised it. "Do you think, my friend," he cried, "do you think that I would not die willingly for this new country if the time should come? Yes, and there are a million like me, once German, now American, who will give their Iives to preserve this tnjon. For without it the world is not fit to Iive in."

Then Judge Silas Whipole sends Stewhen Brice on an e rrand to Iincoln who is favorably impressed with Brice and detains him a day or two in order that he may hear the Freeport Debate. Lincoln is pictured as an ugly man, as an inveterate story teller, and as the possessor of eyes which had a strangely compeling effect upon people. He is represented as being infinitely wise and of intending to give Douglas the senatorship in order to keep him out

\footnotetext{
5 Ibid., p. 122 .
} 
of the White House in 1860. The chapter called "The Crisis" is the one which contains the famous question which Lincoln asked Douglas in the Freeport Debate. Concerning Stephen's trip to Freeport Mr. Churchill says: "That which passed before Stephen's eyes, and to which his ears listened at Freeport, was the Great Republic pushing westward to the Pacific."6 The chapter entitled "The Cris is" ends with this evaluation of Lincoln:

This Lincoln of the black loam, who built his neighbor's cabin and hoed his neighbor's com, who had been storekeeper and postmaster and flat-boatman. Tho had followed a rough judge dealing a rough justice around a rough circuit; who had rolled a local bully in the dirt; rescued women from insult; tended the bedside of many a sick coward who feared the Judgment; told coarse stories on barrels by candlelight (but these are pure beside the vice of ereat cities); who addressed political mobs in the raw, swooping down from the $s$ tump and flinging embroilers east and west. This physician who was one day to tend the sickbed of the Nation in her agony; whose large hand was to be on her feeble pulse, and whose knowledee almost divine was to perform the miracle of her healing. So was it that the Physician Himself perfomed His cures, and when His work was done, died a liartyr.

Abraham Lincoln died in His name."

By the end of Book II the war has started, people have taken sides, and friendships are strained and silenced. In addition to political history, Mr. Churchill gives

\footnotetext{
${ }^{6}$ Ibid., p. 249.

7 Ibid., p. 160 .
} 
social history. He tries to build up a picture of Iife in st. Louis immediately preceding the war. He refers to the sumer vacations and the surmer houses of the well-to-do. He refers to railroads and horse cars. He contrasts Stephen Brice with young $S t$. Louis society which came of Southern ancestry. There are two chapters about the visit of the Prince of Wales and the festivities in his honor, gayety which ignored the portentious rumblings of danger from the oncoming election. In the background German regiments are drilling in preparation for a war for the Inion. Young society men are attending tnionist meetings in secret. At the end of Book II Virginia and Colonel Carvel have left the ir St. Louis home and have gone to their suburban home. The Colonel has volunteered to serve in the Southem amy and has been refused because of his age. Clarence Colfax is in the Southerm army. Stephen Brice is a Lnionist but has not entered active service because he is needed in St. Louis to care for his mother. The boat captain and Carl Richter are in the Inion army. Judge Whipple is a strong tnionist but his health is failing and he is too old to fight. In Book III the country is saved and the characters meet their fates. The first chapter of this last book is called "Introducing a Capital is t." The Capitalist is, of course, Eliphalet Hopper. 
The war has cut off Colonel Carvel's income from the South and has made it impossible for him to bo rrow from the local banks. Eastern debts are due, and the store is about to be lost when Eliphalet offers to pay the debts in return for Colonel Carvel's note. Hopper later uses this note to try to force Virginia to marry him. Still later he threatens to have Colonel Carvel shot as a spy if Virginia will not marry him. Stephen Brice dramatically enters in time to beat Hopper's head against a table. Hopper had paid his own way out of serving in the amy. Colonel Carvel finally goes to war and is killed. Judge Wipple dies on a cot in his own office with his friends around him -- Virginie, her father, Mrs. Brice, Stephen, and Mr. Brainsmade, a Tnionist neighbor. Clarence Colfax, twice helped by Stephen Brice, once when he was injured and once when he was sentenced to be shot as a spy, realizes that Virginia does not love him and releases her from the engagement. After talking with Iincoln, Virginia ceases to hate Stephen Brice because of his Yankee blood and Inionist sympathies. Iincoln is instrumental in completing the romance. The novel ends with Iincoln's death:

In the moming came to them the news of Abraham Iincoln's death. And the same thought was in both their hearts, who had known him as it was given to few to know him. How he had Iived in sorrow; how he had died a martyr on the very day of Christ's death upon 
the cross. And they believed that Abraham Iincoln gave his life for his country even as christ gave his for the world.

And so must we believe that God has reserved for this nation a destiny high upon the earth. 8

As a final word $\mathrm{Mr}$. Churchill has Stephen Brice, many years later, read to his wife the last paracraoh of Incoln's Second Inaugural Address.

Since Mr. Churchill interprets the war historically, our problem now is to see what interpretation he Eives to the history. In the "Afterword" ir. Churchill tells us in so many wors that he tried to take Lincoln's side:

One word more. This book is written of a time when feelings ran high. It has been necessary to put strong speech in to the mouths of the charscters. The breach that threatened our country's existence is healed now. There is no side but dorahom Iincoln's side. And this side, with all reverence and patriotisn, the author has tried to take.

Abraham Iincoln loved the South as vell as the Iorth.9 IIr. Churchill interprets the war as a rebellion which had to be stamped out. His book is based on the beliefs that slavery is wrong, that the Inion could not exist half slave and half free, and that the preservation of this free country is worth every sacrifice.

The same interpretation of the war and essentiolly

8 Ibid., p. 520 .

9 Ioid., p. 522. 
the same pattern may be found in the much briefer novel, They That Took the Sword (1901), by Nathan iel Stephenson (1867-1935), a historian and a native of Cincinnati, where the scene of his story is Iaid. 10

The novel opens on August 30,1862 , in the stately Cincinnati residence of Enfield Dayton, a Unionist. His grand-daughter and the heroine, Amy GoIdine. Iives with Enfield Dayton but is a Southern sympathizer because her father is in the Southem army. Out of respect for Amy, her grandfather has forbidden any discussion of the war in Amy's presence. The hero is a neighbor, Vincent Kainson, who joins the Union army and for a time loses Amy's Iove. Vincent's father, I ike Amy's, is in the Rebel army with another son, Everard Kainson. Both brothers, al though in opposing armies, become involved in some apparently traitorous actions and are brought to trial. Vincent is cleared but Everard is condemed to death. To save Everard's life, Enfield Dayton, Amy, and Vincent, as well as an uncle of Everard's, appe al to Iincoin who arranges for Everard's pardon and also wipes away Amy's objections to Vincent's tnionist sympathies.

In developing this plot, Stephenson pictures the

10 Biographical facts in: Albert Nelson Marquis, editor, Who'g Who in America (Chicago: The A. N. Marquis Comp any, $1936-37$ ). 
spirited wartimes in Cincinnati -- the division of families, secret meetings, the mustering of troops, and the like -- but he begins is novel after the war has started and does not give reasons, as Churchill does, for the conflict. In Stephens on's novel we simply find Cincinnati men courageously defending whatever they deem right. In the end the survivors continue life in the saved Republic.

In interpreting the war, Stephenson, like Churchill, takes Iincoln's interpretation. The novel ends with these words, described as "words which ought to follow as inevitably as the benediction every American undertaking great or small -- God Save the Republic."

Good Southern exarples of these optimistic, patriotic, his torical romances are Manassas (1904) by Cpton Sinclair and The Welding (1907) by mily Lafayette McLaws. After these two novels have been analyzed and their interpretations given, it $w$ ill not be necessary to treat The Battleground (1902) by Ellen Glasgow and The Warrens of Virginia (1908) by George Cery Eggleston as fully, for they will then add nothing to the interpretation of the Civil War given by this type of riction.

Cnusual as it may seem, lianassas (1904), the most extremely Northern, the most thoroughly abolitionis novel of this period was written by a Southemer. Mr. Epton 
Sinclair, the amthor, was bom in Baltimore, Maryland, on September 20, 1878, the son of a Southem leisure class family. However, the family fortune had been swept away by the Civil War, and while the leisure class tradition remained, there was no money. Mr. Sinclair was thinking of himself when he made the central character a Southerner converted to abolitionist views. He himself is an aristocrat converted to Socialist views. At the time he wrote Manassas he was beginning to recognize the beliefs and opinions that he had developed from his personal experience as also those of a group of people called Socialists.ll Incidentally, it was a Socialist, George D. Herron of New York, who gave Mr. Sinclair the money to live on while he wrote Manassas. Mr. Herron advanced two hundred dollars and then paid Mr. Sinclair thirty dollars a month during the year that it took to write the novel. Concerning Manassas, Mr. Sinclair says, "I had exchaned my Virginia ideals for those of Massachusetts, and was intending to portray the Civil War from the Yankee point of view." 12 He intended to write a trilogy of novels:

-. "Manassas," "Gettysburg," and "Appomattox"

II Tpton Sinclair, American Outpost (New York: Farrar and Rinehart, 1932), pp. 140 ff.

12 Ibid., p. 132 . 
were to be the titles of these mighty works, and by contemplation of the heroism and glory of the past, america was to be redeemed from the sordidness and shame of the present. 13

Manassas, of course, was written, but the other two novels did not materialize.

Mr. Sinclair wrote Manassas "that the men of this land may know the heritage that has come down to them.n14 By "know the heritage" Mr. Sinclair means "know the country through its his tory." He wants "the men of this land" to know what battles were fought and what sufferings were endured in the making of this free country in order that by contemplating the past they may remedy the social evils of the present. It is important to note, however, that in interpreting the Civil War, Mr. Sinclair gives an abolitionist interpretation and not a socialistic one. There is no more socialism in Manassas, than there is in The Crisis. In both novels it is I imited to one German Socialist character.

The theme of Manassas is the history of our country from the Revolution to the Battle of Manassas, or Bull Run, with the emphasis on events leading up to the CiviI

\section{Ibid., p. 131}

14 Epton Sinclair, Manasgas (New York: The Hacmillan Company, 1904), Fiyleaf. 
War and especially on the abolitionist movement. Mr. Sinclair includes all the political events, between about 1848 and 1862, that are included in histories which trace the events leading up to the Civil War. He goes into minute detail in showing the workings of the abolitionists. The chief respect in which Sinclair's history is incomplete is in the omission of conservative viemoints. Mr. Sinclair emphasizes the intense feeling of both sides and includes only the extremists. Manassas reads like a history book except that it is partisan and emotionalized his tory.

In developing his his to rical theme Mr. Sinclair endeavors to bring the history to life by making it in some way enter the experience of the central character, Allan Montague, the son of a Mississippi plantation owner. Further than this there is no plot. The story opens about the year 1848 on the Mississippi plantation with Grandfather Montague telling eight-year-oId AIlan and his cousin Randolph stories of the Revolutionary War and urging them to love their country and to give their best to her. Then abruptly, Allan's father, with Allan, goes to Boston to live in order to take care of the interests of the plantation. The father remains strictly Southern in his sympathies, but Allan becomes an abolitionist. mile in 
Boston, in addition to preparing for and entering Harvard, Allan meets Ievi Coffin, the "Tnderground Railroad" abolition ist, hears Frederick Douglas, the negro pleader for abolition, reads Incle Tom's Cabin, and hears of the repeal of the Missouri Compromise. Just before the outbreak of the war, when Allan is in his second year at Harvard, his father announces that they will return to Mississippi. Tnable to discuss his abolitionist leanings with his father, Allan goes back to the plantation. Shortly after their arrival two events occur on tine same aftemoon which send Allan to the North again. In a burst of feeling Allan shows his family where his sympathies are; and his father is brought home dead, having been killed in an accident caused by a runaway horse. Allan goes to the North and, when the war begins, enlists. Sometime after his enlis tment he visits Iincoln and finds him a kindly, awkward man, and an inveterate s tory teller. Among the men Allan meets in the army is Sergeant Schlemrer, a German Socialist. He fills about the same place in this novel that the German, Carl Richter, fills in the Crisis. The following quotations give, in part, Schlemmer's history :

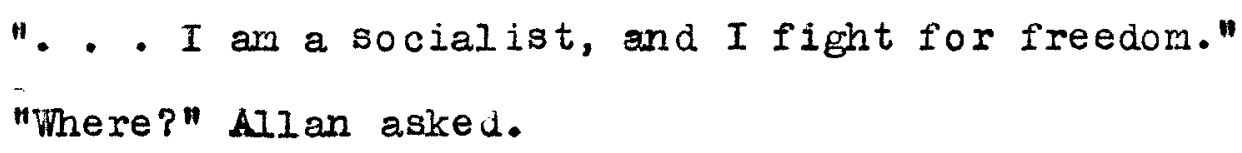




\begin{abstract}
"In many places I have helped," said the other.. - "Wherever there was fighting, in ' 48 and '49. I was in Poland, and then in Saxony. I was in the street fighting in Dresden, when we tried to overthrow the monarchy. I was on the barricades..."
\end{abstract} asked.

"How long have you been in this country?" Allan

"Eight years I have been here," said sergeant Schlemmer. "When I was married, I came."

"Oh," said Allan; "then you have a family?"

"I have three children," the man replied.

"But how can you leave them to go to war? -- What will they do?n

"They have a little," he said.. . "they will get along. Your people will help them, perhaps, and my comrades have promised."

"And you like this country well enough to fight for it?" Allan inquired.

"AIl the world is the socialist's country," the man answered. "When we fight for freedom; it does not matter to us where we fight."115

In his first battle, the Battle of Manassas, Allan acts very much as Crane's Henry Fleming did. Mr. Sinclair's description of the battle sounds like Crane and Bierce combined. Notice the change here from a desire for some real fighting to a fear of the battle.

Saturday evening, the twentieth day of July, the orders came at last. Cooked rations were distributed, and the regiment was ordered to march at half-past one the following moming. Everybody felt that this time

\title{
15 Ibid., pp. 356-357.
}


it meant business -- that the death grapple with secession was coming.

The men discussed it, sitting in groups, some of them busily cle aning the ir rifles. Others, who happened to be of a meditative tum of $m$ ind, went apart, feeling solemn. They were students, and business-men, and clerks, the se volunteers -- as for fighting, some of them had never been in so much as a fist fight in their lives. A battle was a thing about which they lnew through books, a thing that had always seemed as far away and impossible as the Arabian Nights. And now there was going to be one -- here! tomorrow! And they were going to be in it! How strange it was to think about! Bits of incidents they had read would float in to their minds -- things bloody and terrible -- and now suddenly become real! One looked at his companions, wondering. Did they know what they were going to do -- did they realize what it was going to be like? Could it possibly be that they did, and that they did not $m$ ind it any more than they seemed to? What uncomfortable people they had suddenly become! And how overwhelmingly you felt your own inferiority -- quaking and upset as you were.

You imagined yourself in the battle... Such a very ticklish feeling came over you; so strangely aware you became all at once - of your stomach! Your stomach was such a soft and mushy thing; surely if a man had been intended to go into a place where bullets were flying, he ought to have had some $k$ ind of a hard coating over his stomach. 16

Note the realism in this description of the aftermath of a real battle:

It was a real battle, there was no mis take; it was a victory, too -- the fighting was a rile or two ahead, and yet it had once jeen where they were! Here and the re over the fields they could see the debris of the conflict...

But some of the things you saw here were far from glorious. Wounded men we re coming down the road... And then sudden Iy -- underne ath a tree -- God, what a sight was that! The hospital corps had taken its 
stand here, and raised its flag; men were lying stretched out in sows -- and right in the roadside was one upon his back, with a surgeon bending over him. The man's face was upturned, white as a sheet, and savagely distorted. He was clutching his sword in one hand, and the cords stoo out upon the hand. The surEeon had sliced away the man's trousers, and he was mechanically sawing away at his leg. You heard the saw rasp at $h$ is bone .. ugh! I7

Compare this incident with the similar one in The

Red Badge of Courage:

And then suddenly from somewhere opposite there burst out a cloud of smoke and flane, and Allan heard at $h i s$ side a crusbine, spatting sound, and felt his cousin, whom he still Erasped with one arm, half torn out of it. Things smote him in the face, cutting him, tearing him, blinding him; and over his hands there rushed flood of something hot and horrible. In a spasm of fricht he shook his head free and wiped clear his ejes - staring, Jack - Ereat God, where was Jack! Here was his body, and above it a neck-bone sticking up, and a jaw dangling in front of it and out of the middle, gushing up as from a fountain -- pumping, pumping - a jet of crimson blood!

AlIan reeled, and stageered backwards with a scream; and the body luneed forward, a stream of blood gushing forth and slopp ing over his feet. The sky seemed to grow black before $h i s$ eyes; the trees danced and swayed, and he clutched his hands over his face. Shudder after shudder pessed through his frame -- and then, suddenly, with a choking cry, he tumed and fled eway. 18

The novel ends, after the Battle of Manasas, with the following song sung by three of Allan's Southern

16 Ibid., pp . 384-385.

17 Ibiä., p. 390.

18 Ibid., pp. 393-394. 
cousins :

"War to the hilt!

Theirs be the guilt,

Who fetter the freeman

To rensom the siave!"I9

Encouraged by their victory these Southe rn aristocrats were laying the blame for the war at the door of the North who, they thought, was trying to enslave southern whites in order to free the negroes.

Mr. Sinclair interprets the war by giving its causes and by giving a psychologicaliy realistic picture of actual fighting. The war was caused, accoraing to Mr. Sinclair, by the North's humanitarian in terest in the negro and the South's defense of slavery. He backs up these causes with a wealth of historical incidents. Mr. Sinclair stops this first volume of his proposed trilogy with the Battle of Manassas, which was lost by the North. The inference is that still more suffering had to be endured, still other bloody batties had to be fought to give us this free country as our heritage. Mr. Sinclair wrote the novel "that the men of this $I$ and may know the heritage that is come down to them." Mr. Sinclair interprets the war as a war against slavery and for freedom. The Welding (1907) Was written by Miss Fily Lafayette McLaws, a native of Augusta, Georgia. The novel is 
dedicated to her uncle, Major-General Lafayette liclaws of the Confederate army. Her mother's maiden name was Sarah Twiggs and in The Welding there is a Colonel George Twiggs, son of a Revolutionary soldier, and two other characters bearing the name of Twiegs as a given name. Miss McLaws wes educated under Eovernesses and tutors at home and Iater in Boston private s chools. After the death of her parents she went to New York under the chape ronage of Mrs. Jefferson Davis. Ste speaks four modern languages besides English. Her fiction deals criefly with historical themes. 20

Miss McLaws's purpose in writing The Welding (1907) is very similar to Tpton Sinclair's in Hanassas. Instead of "That the men of this land may know the heritage that is come down to them," Miss McLaws quotes from Lincoln's Gettysbure Address. On a flyle af at the beginnine of the Welding are the words:

That we here highly resolve that these dead shall not have died in vain; that this nation, under God, shall have a new birth of freedom; and that government of the people, by the people, for the people, shall not perish from the earth.

\footnotetext{
20 Migs McLaws is the author of When the Land Was Young (1901), Jezebel (1902), Maid of Athens (1906), The Velding (1907), In the Dust of Defeat (1910), and Evenings with Irss. J. Davis (1910). Biographical facts from A. N. Warquis, ejitor, Who's Who in Americe, 1912-1913 (Chic aé: The A. N. Marquis Company, 1899-1939). No birth date is given.
} 
The theme of The Welding is indicated by the title. It is the pressing of the two halves of our nation into a closer tnion. Iincoln is the welder, and the abolition of slavery is the condition necessary to the welding.

The novel is divided in to three books: Book I "Which Deals with Conditions," Book II "The Fusing of the Inion," and Book III "The Welding of the Nation." In Book II the Cnion was dissolved, and in Book III the nation was again made into one. The principal scene is Georgia. The first book describes the social classes in the South, indicates that there is anti-slevery aeitation going on more or less under cover, refers to slaves' running away, and describes a slave auction and the inhuman treatment some of the slaves suffered at the hands of their owners. The abolitionist attitudes are expressed in the following quotation from papers one fictional character brought with him to Georgia:

Jefferson said: "One day of American slavery is worse than a thous and years of that we rose in arms to oppose."

The Declaration in the Constitution of the American Anti-Slavery Society: We maintain that no compensation should be given the plenters for emancipating their slaves, because slavery is a crime and therefore not an article to be sold. We shall orgenize anti-slavery societies in every city, town, end village in our land. We shall spare no exertion nor means to bring the whole nation to repentance, whether we Iive to witness the triumph or perish, untimely 
martyrs in the great, benevolent, and holy cause. Book II fuses or dissolves the lnion by the he at of antislavery agitation and war. It gives a survey of events from 1849 to after the beginning of the war. David Twiggs Hamilton, the central character and the character through whose eyes we saw the conditions described in Book I, has los $t$ both his father and $h$ is mother and has gone to Congress as a page for Alexander Stephens. David knew the evils of slavery from personal experience, but he lnew that Georgia came into the Inion with honestly bought slaves, and he, influenced by Alexander Stephens and by home ties, remains loyal to Georgia. The historical background for the years 1849 to 1861 is indicated by the mention of Uncle Tom's Cabin and John Brown, both attacking slavery from a humenistic standpoint, by the mention of The Impending Crisis, which attacked slavery from an economic point of $v i \in w$, and by the mention of the IincoinDouglas debates. Alexander Stephens, a Georgiaman, of course, is made a hero, and, eccording to Miss McIaws, would have been the president of the Confederacy had he not refused on the Erounds that he was unwilling to strike the first blow at the inion. In this book there is the usual division of lovers. The heroine is a Northerner. Book III, "The Welding of the Nation," presses the nation 
into intimate and permanent union while it was softened by the heat of war. The book ends the war and unites in marriage both a Southern hero with a Northern heroine and the Northern brother of the heroine with a Southern girl. Ijncoln performs $h$ is inevitable service of $s$ aving a young man from death at the heroine's request. This time it is her brother who is in Iibby Prison and condemned to be hanged. Iincoln arranges an exchange of prisoners.

The Welding interprets the war just as Manassas does: the cause, slavery; the result, a free nation; the actual fighting, horrible brutality.

A third Southerm novel written in this same trend is The Battleground (1902) by Ellen Glasgow, \& native of Richmond, Virginia, borm on April 22, 1874. In addition to this historical romance dealing with the Civil War, Miss Glasgow has written three others on the post-war pe riod: The Voice of the People (1900), Deliverance (1904), and The romance of a Plain Man (1909).21

The theme of The Battleground is the Iife of the people of two wealthy Virginia $f$ amilies. The heroine is Betty Ambler of Cplands Plantation, the daughter of a former governor of Virginia. The hero is Dandridge lifont-

\section{$2 I$ Biographical facts from Living Authors.}


joy of Chericoke Plantation, the Erandson of Major Iightfoot, a veteran of the Mexican War. The other characters include relatives, friends, and slaves, but no liorthern characters and no historical characters. The scenes in the first two books of the novel, "Golden Years" and "Young Blood," are laid on the plantations where the love story of Betty and Dan begins and where conversations foreshadow the oncoming confict. The scenes in the last two books, "The School of War" and "The Return of the Vanquished," follow the Virginia regiment through the war and back home where Dan and Betty are ready to work together to live in the changed South.

In interpreting the war Miss Glasgow presents the contrast between the Iluxury of the Southemer's lives before the war with the extreme poverty which accorpanied and followed it. In the army scenes pain, weariness, and hunger are emphasized along with the love for Virginia and for lee which made the men willing to fight. The soldiers fought for Virginia, not for slavery. Governor Ambler loved the Union, eithough he loved Virginia more, but he did not like slavery. Miss GIasgow leaves us with the impression that even though the South was battlescarred it was better that the slaves were freed. George Cary Eggleston, the author of Southern Sol- 
dier Stories (1898), also wrote \& historical romance on the Civil War -- The Warrens of Vireinia (1908). It contains most of the elements we have found in the other novels. The theme is the important phase of our national history. The story movement, indicated by the titles of the four books -- "The Brealing of the Bonds," "The StrugEle of the Giants," "The End of an Epoch," and "Chapter First and Last" -- records the progress of our country from slavery through disunion to a more perfect inion. The Iove story behind the national his tory is the familiar one. The Northerm hero, Edgar Burton, falls in love with the Southern heroine, Agatha Warren, before the war, seemingly loses her because of his opposing symathies during the war, and is forgiven and accepted by her at the end of the war. The interpretation of the war is just what we have found in all the novels of the first decade of this century: the war was horriole but necessary to the progress of our country.

After this wave of nationalistic patriotism began to recede, there is disillusionment conceming the war. Mary Johns ton believes that all war is bad. Her two Southem novels show a trend in Civil war interpretations toward intemational, humanitarian sentiment. Mary Johnston's purpose was not to remind us of our heritage but to 
remind us of the horrible side of war.

Mary Johns ton was bom on November 21, 1870, at Buchanan, Botetourt County, Virginia, the daughter of Lajor John William Johns ton, a Confederate veteran, lawyer, and ex-member of the Virginia legislature. Her father's library was undoubtedly full of histories and it is probable that his daughter received the background for her Civil War novels from his library. 22

The Iong RoII (1911) and Cease Firing (1912) may be taken together as one long novel. The characters are the same and in point of time the two novels overlap very little. The Long RoIl begins in 1861 and ends in May, 1863, with Stonewall Jacks on's death, and Cease Firing begins in December, 1862, and ends in April, 1865. The historical background in these novels is military, rather than political as it was in The Crisis, Nanassas, The Welding, and others. Miss Johnston followe in cetail the movements of the Army of Northem Vireinia. It seems to me that all the vell known Bouthern leaders as well as a fev Northern ones appear or are mentioned in the story. The Southern leaders are loved, cheered, and praised by their soldiers. The fictional characters, as may be ex-

\section{Biographical facts from Living Authors.}


pected in historical romances, represent the various social classes. Richard Cle ave and Judith Cary, the central characters, belong to the Virginia plantation aristocracy. The Cleave family lived on Three Oals Plantation, and the Cary family on Greenwood Flantation. Judith's brother Edward narried a Eirl from Cape Jessamine Plantation in Louisiana. Maury Stafford, enother southem aristocrat, was Richard's rival for the hand of Judith Cary. Below them in the social scale was Allan Gold, who before the war was a school teacher on Thunder Run Mountain. Aunt Sairy, his aunt, and Ton, her husband, who was the tolI gate keeper at Thunder Run llountain, the Haydew family, ignorant whites, and Steve Dagg, a worthless loafer of the poor white class. There is one Horthem fictional character, Colonel Francis Marchmont, a Northern spy.

The story is briefly this: Richard Cleave, Colonel of the 65 th Virginia Regiment, was falsely accused by his rival in love, Maury stafford, of bringing disaster upon his men in a battle. Cleave resigned his comission, took the name of Philip Deaderick, and served as a private until long after when Maury Stafford cleared him. Richard and Judity were married at the end of cease Firing and they vowed to teach their children to love Virginia. The The other Iove story, that of Edward Cary and Desiree 
Gaillard, was quite different. Edward, an infantry man, and Desiree were married during the war. Desiree followed the army so that she might nurse Edward if he were wounded. Once she saved his life but later they both were killed.

This fictional plot is of minor importance. The characters are slowly introduced as the story of the armies is followed from the beginning of the war to the e.d. Battle after battle and death after death are described. From time to time Miss Johns ton gives us glimpses of life behind the lines -- of non-combatants watching parades, trying to exist under strange onditions, helping in hospitals, and fleeing from buming homes. Several times characters give their reaction to or opinions of the war. The following quotations give opinions of several social classes:

General Johns ton: I believed that, epart from any right of secession, the revolution begun was justified by the maxims so often repeated by Anericans, that free government is founded on the consent of the govemed, and that every comunity strong enough to establish and maintain its independence has a right to assert it. My father fought Great Britain in defence of that principle. Patrick Henry was my mother's uncle. Having been educated in such op inions, I naturally retumed to the sita of which I was a native, joined my $k i$ th and $k i n$, the people among whom I was born, and fought-- and fight .- in their defence. 23

\footnotetext{
23 Mary Johns ton, Cease Firing (Boston: Houghton, 1912), p. 29 .
} 
Two soldiers: The guns echo so. Here they come ! And God knows I am sorry for them -- for Abner here and Abner the re! Martin, I hate war.

It ain't exactly Christien, and it's so damed avoidable. . . The baby died, and I recon his wife -- and she was a sweet, pretty Eirl -- 'II 60 to the Asylum at Wilizams burg. .

Billy Maydew, an ignorant mountaineer: "I don't know that I hate anybody now," said Billy aloud.

"Don't you?" asked the man next him. "I wouldn't be a namby-pamby like that! I couldn't get along without hating, any more than I could without tansy in the spring-time!"

"Oh, thar air times," said Billy equably, "when I think I hate the Yanks."

\section{"Think! Don't you know?"}

Billy was counting the cartridges in his cartridge box. "Why," he said when he had finished, "some times of course I hate them like p'ison oak. But then thar air other times when I consider that -- according to their newspapers - they hate me like p'ison oak, too. Now I do a power of wrong things, I know, but I air not p'ison oak. And so, according to what Allan calls 'logic', mayce they air not p'ison oak either. That was $a$ man in the Wilderness. The fire in the scrub was coming close enough to feel the devil in it -closer and closer. And $h$ is spine was hurt and he couldn't move, and he had his shoulder against a log, one end of which was blazing. He was sitting there all lit up by that light, and he had his wusket butt up and was trying to beat out $h$ is brains. Me and Jim Watts got him out, and he was from Bos ton and a young man like me, and I liked him just as well as ever I liked any man. He put his arms around my neck and he hucged me and cried, and I hugged $h i m$, too, and $I$ reckon I cried too. And $h_{i}$ in and me got $h$ im out through the scrub afire. He wa'n't no p'ison oak, no more'n I were."

\section{Ibia., p. 42.}


"Well, what're you fighting for?" "I am fighting," said Billy, "for the right to

The end of the book. Allan Gold: "I think that we were both right and both wrong, and that in the beginning, each side might have been more patient and much wiser. Life and $h i s t o r y$, and right and wrong and minds of men look out of more windows than we used to think. Did ou never hear of the shield that had $t$ wo sides and both were precious metal? The traveller who said, 'This is a gold shield,' was right -- half $r$ ight. And the traveller who saic, 'This is a silver shield,' was right - half right. The trouble was neither took the trouble to walk round the shield. So it is, I reckon, in most wars -- this one not excepted! of course, being in, we've done good fighting . . "26

Mary Johnston interprets the war real istically. Her description of Pickett's charge at Gettysburg reminds one of The Red Badge of Courage. Her purpose, however, goes farther than Crane's; she is pleading for wars to cease.

And now we come to The Financier (1912) by Theodore Dreiser, 27 who was borm in Terre Haute, Indiana, on Augus $t$ 27, 1871, wrote The Financier (1912) to trace the career o of a capitalist from 1837, the year of the capitalist's birth, dow to the panic of 1873. The setting of the novel is Philadelphia. At the time of the war Frank Al-

\footnotetext{
25 Ibia., pp. 301-302.

26 Ibid., p. 457.

27 A good study of Dreiser is Burton Rascoe, Theodore Dreiser (ifew York: R. Mr. McBride and Company, 1925 ).
} 
gernon Cowperwood, the financier was "a cool detemined youth."28 He thought that the slavery agitation might be founded in human rights, but that it was extremely dangerous to trade. The freedom of the negro was not the important point to him. He was not sure that negroes could be made into anything more significant than they were. He hoped that the North would win, but he saw no $r$ eason why the South should not protest. He himself did not want to fight and he called the men who enlisted "the poor overwrought working-man."29 He pitied them and thought that they did not know what they were doine. The current warspirit was strange to $r_{i}$.

He did not care to fight. That seemed silly for the individual man to do. Others might -- there were nany poor, thin-minded, half-boked creatures who would put themselves up to be shot; but they were only fit to be commanded or shot down. As for $h$ in, his life was sacred to $h$ imself and $h$ is family and his personal interests. 30

His personal attitude toward the war, however, and aside from his patriotic feeling that the tnion ought to be maintained, was that it was destructive and wasteful. He was by no means so lacking in patriotic emotion and sentiment but that he could feel that the Inion, as it had now come to be, spreading its great length from the Atlantic to the Pacific and from the snows of Canada to the Gulf, was worthwhile. 31

28 Theodore Dreiser, The Financier (New York: Harper, 1912), ․ 65 .
29 Ibid., p. 65.
30 Ibia., p. 65 
One day Cowperwood saw Iincoln, and from then on the President's greatness was impressed upon him. Dreiser says: "War and statesmanship were not for hin; but he knew how important such things vere -- at times." 32 During the war Cowpe rwood made noney by helping to supply the government with money through stocks and bonds. However, he was anxious for the war to end: "This fratricidal war in the nation could not help him. It really delayed, he thought, the true commercial and financial adjustment of the country and he hoped that it would soon end."133

This is just about the extent of Dreiser's interpretation of the Civil war. Cowperwood is especially interesting to this study when compared with Churchill's Eliphalet Hopper and with the recent treatments of the capitalist which will be discussed in the next chapter of this thesis. By 1912 the wave of patriotism was receding and the capitalist was not so contemptible as he had been in 1901.

\footnotetext{
31 Ibid., D. 84

32 Ioid., D. 67.

33 Ibid., p. 85.
} 
To sum up: Between 1900 and 1919 the trend in fictional interpretations of the American Civil war seems to be, first, a patriotic pride in our nation's history and, secondly, a pacifist movement. With the turn of the century the fictional interpretations of the American Civil War shift from the interest of the eighteen-nineties in picturing with psychological realism wartine experiences of individuals to an interest in interpreting the war as a national experience. It is a shift from a psycholozical interest in war to a patriotic interest in this particular war. After the Spanish-American Jar nationalism and imperialism were in the air. Business conditions vere good, and well-being characterized the early years of the new century. The Civil War became one colorful evoch in the past of a nation which was looking toward a glorious future. But, this patriotism waned. The last historical romances are anti-war in sentiment, showing the influence of the international pacifist movement.

The next chapter deals with the fictional interpretations of the Civil War which we re written after the World War. In their general, external pattern they resemble the historical romances, and in their interest in individual psychology they resemble the short $\mathrm{s}$ tory writers of the eighteen-nineties. However, their interpreta- 
tion of the war is different from any we have found; it is an economic interpretation. 
CHAPTER IV

PSYCHOLOGICAI : NATCRAIISM AND IITDSTRIAIISM $1920-1939$ 
CHAPTAR IV

PSYCHOLOGICAI: NATLRAIISM AND INDLSTRIAIISM

$1920-1939$

In the period from 1920 to 1939 there are twentytwo items in my bibliography of Civil War fiction. 1 of these three deal with much longer periods of time, three are adventure or love stories, two make the war secondary to mother theme and one is a juvenile story. The remaining thirteen novels are interpretations of the War. Five of them were written by Northemers, and eight by Southemers.

The earliest Northe m interpretation is John Brown's Body (1927) by Stephen Vincent Benet. Being an epic poem and not a novel, it really does not come within the bounds of this thesis, but its panoramic treatment of the war is pertinent. MacKinlay Kantor furnishes the next two Northem interpretations in his novels, Long Remember (1934) and Arouse and Beware (1936). The first covers two months

1 This number probably should not be compared with the numbers for the other three periods. For the first two periods I used the bibliography compiled by Miss Smith, who had more available sources than I have. For the period from 1900 to 1919 I used Frnest Albert Baker's Guide to Historical Fiction (1904) which covered the early years. But, for this last period I had no assembled bibliography to start from. 
of the war, and the second only ten days. Yet, Kantor's accounts of the experiences of his characters in those brief periods present good psychological studies of the war. The most recent of the Nortinem novels are Royce Brier's Boy in Blue (1937) and Hervey Allen's Action at Aquila (1938). Boy in Blue (1937) tells how the Civil war affected an Indiana farm boy. Action at Aquila (1938) tells what it meant to a veteran of the Mexicen War whose home was in Pennsylvania.

The earliest Southern novel of this period, Marching On (1927) by James Boyd, interprets the war from the point of view of a Southemer who is not a slave owner. The next one, The Wave (1929) by Evelyn Scott, is panoramic in its view of the war. So Red the Rose (1934) by Stark Young, Gone With the Wind (1936) by Margaret Mitchell, Bugles Blow No More (1937) by Caroline DuffGordon (Mrs. Allen Tate) all deal with the experiences of Southemers in definite localities and with the overthrow of the Southem civilization. The Lnvanquished (1938) by William Faulkner also does this, but it tells of some people who were not conquered. The Fethers (1938) by Allen Tate pictures the overthrow of the planter aristocracy and also the career of an individualist who is a kind of capitalist. 
The se novels give economic and psychological interpretations of the war. In their general pattern they resemble the historical romances, but they replace the political interest of the romances with an interest in the economic significance of the conflict. In addition, the use of psycholoeical analys is is shifted in many cases from the battlefield to the Iife behind the lines. These novelists try to re-create the war as it was experienced by people contemporary with the war. They interpret the war as a force in nature, as a characteristic of human nature, and as a money var. More often, however, they interpret it as a phase of the Industrial Revolution, as the triumph of industrialism and the defeat of the planter civilization.

Stephen Vincent Benet, who was born in Bethlehem, Pennsylvenia, on July L2, 1898, gives us the earliest Nortiern interpretation of the American Civil War in this period, John Brown's Body (1927). It is not surpris ing that Benet chose the Civil War as a Iiterary subject. Many reference books about the war were in his father's library. The various sections of the country and the life of army men were familiar to him because his father was in 
the army and took $\mathrm{h}$ is family with him to each place in which he was stationed. Benet's grandfather and his great-Erandfather were also professional coldiers. Benet became a poet instead of a soldier, but he wrote, at least once, on a military theme. Writing, 2 lso, seems characteristic of his family. His older brother and sister, William Rose and Laura, are both poets and critics.2

Mr. Benet, in John Brown's Body (1927), says that sometimes in nature a blind, unreasoning force arises and, like a stone, batters down whatever is in its way. John Brown had a blind, unreasouing, fanatical belief that the slaves must be freed, or, rather, that he must free the slaves. He was killed, but the sympathy aroused by his martyrdom in the cause made John Brow's body act as a stone in battering down slavery.

Sometimes there comes a crack in Time itself. Sometimes the earth is torn by something blind. Sometimes an image that has stood so long

It seems implanted as the polar star

Is moved against an unfathomed force

That suddenly will not have it any more. Call it the "mores," call it God or Fate, Call it Mansoul or economic law,

That force exists and moves.

And when it moves

It will employ a hard and actual stone

To batter into bits an actual wall

And change the actual scheme of things.

2 Biographical facts from Dilly Tante, editor, Living Authors (New York: The H. W. Wils on Company, 1931). 
John Brown

Was such a stone -- unreasoning as a stone,

Destructive as the stone, and if you like,

Heroic and devoted as such a stone. ${ }^{3}$

The theme of the poem is the influence of this

force, symbolized by John Brown's body, in the destruction of the old South. As Mr. Benet develops this theme we see the stone moving through the country, uprooting and overthrowing the established systems of life in all classes of people. In the foreground we have Clay Wingate, a Southern aristocrat, fighting for "somethine so dim that it must be holy." $\mathrm{He}$ is willing to "live and die for Dixie." This is the trend of his musings:

Why were they all going out to war?

He brooded a moment. It wasn't slavery, That stale red-herring of Yankee knavery

Nor even states-rights, at l east not solely, But something so dim that it must be holy.

If there ever has been a land worth saving -'In Dixie land, I'll take my stand, And live and die for Dixie !4

In contrast to Clay Wingate there is Jack Ellyat, Connecticut bo $\mathrm{m}$, son of a farmer. His parents are in sympathy with John Brown's followers, but Jack has not even a dim

\footnotetext{
3 Stephen Vincent Benet, John Brown's Body (New York: Doubleday, Dor an and Compeny, Inc., 1928), p. 56.

4 Ibid., p. 77 .
} 
purpose in his fighting. When he dreams, he dreams of home and peace. The minor characters, also, bring out the inevitable submission of all classes of people to the unreasoning stone. A Pennsylvania farmer, two mountaineers, a negro slave, and such historical figures as Lincoln and Gront are carried along by that force. It brings no happiness to them. They did not seek its influence, but they cannot escape.

$\mathrm{Mr}$. Benet interprets the war as a reality, unreasoning in its course, neither good nor bad, but simply there. The force which carries the people along is part of an ultimate energy expending itself in the war. It is a kind of mystic energy which does not come into man's consciousness.

Mackinlay Kantor's interpretation is somewhat different. His novels dwell primarily on life behind the Iines, and the breadth of his view is limited to the experiences of his central characters. Mr. Kantor, who was born at Webster City, Iowa, on February 4, 1904, approached with great seriousness the task of faithfully interpreting the Civil War to the present generation. At the end of Arouse and Beware (1936) he inserts a bibliography of the works that he used in getting material for the novel. Iong Remember (1934) is based on the same, or 
similar, sources. Mr. Kantor's interest in the war, Iike Mr. Benet's, has probably been Iifelong, for he is a member of the National Association of Civil Var lusicians, Sons of Union Veterans. In addition to these two war novels he has written Civil War stories for periodicals. 5 The theme of Iong Remember (1934) is what people did and suffered at Gettys burg because of the Battle of Gettysburg. Mr. Kantor points out that contrary to Iincoln's prediction, we heve remembered what he said at Gettys burg and have forgotten what men did there. Mr. Kantor says :

It is wortry to remark that whatever astuteness Abraham Iincoln possessed as a prophet, was not reflected in his address at Gettysburg, on November 19 , 1863. With all sincerity he declared, "The world will little note, nor lone remember, what we say here, but it can never forget what they did here." Seventy years later one realizes that lincoln's speech represents the only comion and popular knowledse of I jincoln, Gettysburg, or the war betreen the states. 6

$5 \mathrm{His}$ other 1 iterary work includes work as a reporter for the Webster City Daily News (1921-1924), advertising and clain correspondence work in Cicago (1925$192,6)$, work as a reporter and free lance writer (1927), work as columnist for Des Hoines Tribune $(1930-1931)$, and work as a scenario writer for Paramount Productions (1934). He has written novels, verse, and magazine contributions. on July 2, 1926, he married Florence Irene Layne of Chicago, Illinois. They have two children, Carol Layne and Thomas. Their home is in westfield, New Jersey. Facts from A. $\mathrm{N}$. Marquis, editor, Mho's Who in America, 19361937 (Chicago: The A. N. Marquis Company, 1899-1939).

6 mackinlay Kantor, Long Remember (New York: The Iiterary Guild, 1934), Flyleaf. 
Taking his title from Iincoln's speech, Mr. Kantor tries to tell us what we have not remenbered. He re-creates the battle as it entered the experience of a small group of fictional characters.

The entire story takes place in Gettysbure. Pennsylvania, in June and July of 1863. Daniel Bale comes home to Gettysburg. Pennsylvania, from Minnesota because of the death of his grandfather. He has not jo ined the army because he does not believe in killing people for any reason. He is not a Copperhead, although some people in Gettysburg believe that he is. All the other young men in Gettysburg except the Coppe rheads seem to have joined the army, and Daniel is left in the unenviable position of one Who attempts to be different from the crowd. Infortunately he falls in love with and is most sufficiently encouraged by the wife of a close friend who has gone to the war. Daniel expects Irene Fanning to divorce Tyler Fanning, and if it had not been for the war she might have. Anyhow, Tyler learns of the situation and writes to Irene asking her to let him know at once if the accusation is false. Irene does not answer the letter, and days pass in which she continues her unfaithfulness. Then she begins to have visions of Tyler being killed by a sword. She feels that she cannot let him die believing her unfaithful, and 
she sends Daniel Bale to $s$ ay that the accusation is false and groundless. For her, he does it and even kills a man to carry out her desire. Daniel also helps to bring Tyler home to her when he is wounded, but Daniel still hopes that Irene will give up Tyler and marry him. Irene lived with Tyler's mother and father and that home was the only place to take the wounded man. From then on, hovever, Irene gives Daniel no more encouragement. She tells him that Tyler's leg has to be amputated, that he fill have but one leg, but that still he is her husband. Daniel thinks that if she only possessed sufficient courace she would leave Tyler and go a way with him. But Irene stays with Tyler, and Daniel goes to jo in the army. The war had made Irene faithful to her husband. Tyle $r$ had to have some one's approval. He preferred a woman's love to the community's respect, but losing the former he did that which would bring him the latter.

Outstanding among the minor characters are Dr. Adam Duffey, Hijah Huddlestone, and melia Niede. Dr. Duffey is the typical small town doctor with all $h$ is common sense, sympathy, and personal interest in his patients. He sees Dan's trouble in his face and tries to help him, but Dan will not confide in anyone. During and after the Battle of Gettysburg Dr. Duffey attends the wounded sol- 
diers, sometimes with Dan's help. Elijah Huddlestone represents the type of boy whose heart and soul are tied up in being a soldier. He is poor and physically handicapped, but fighting for the tnion is glorious to him. He is in love with Amelia Niede, a rather colorless girl, and had Flijah not been killed they would have married. Elijah and Dan were friends from childhood and during the trying events of the story they help each other as much as they can. At last Dan finds Elijah's body and buries it. One other minor character should be mentioned -- Quagger, a Copperhead. He is the one who tells Tyler about Irene and Dan. He does it because Dan knocked him dorn for calling him a Coppe rhead.

The war is interpreted in Lone Remember (1934) as an influence on the lives of these fictional characters. In adition, there are descriptions of warfare as realistic as any ever written. In this novel there is neither sectionalism, nor politics, nor justification of the war, nor condemation of it. Long Remember (1934) gives a psychologically realistic picture of the effect of the Battle of Gettysburg on a few people.

Arouse and Beware (1936) is a pychologically realistic account of the escape of three people, two men and one woman, from Richmond to the Union lines, en escape 
which took place between March 3, 1864, and March 12, 1864. The men were escaping from Belle Island Prison, and the woman, from a Confederate general. The background gives a true picture of certain phases of life during the Civil War: the doings of the Home Guards, the work of the Tndereround Railroad in helping white Loyalists to escape, the I ife of covards and injured men, who were not fighting, and the terrible suffering in prison.

The title, "Arouse and Beware," has a double significance. It characterizes the life of the escaping characters and it also refers to an incident in their personal relations which is recorded in the second book of the novel. Mr. Kantor cives the following as the source of his title and story:

In that nightmare realm of reality which novelists $v i s i t$ in search of persons and circumstances wholly unreal, the author discovered this tale written in two large discarded daybools. It bore every evidence of having been set down painfully and carefully, but at white heat of enthusiasm, through a period of years. The caption was "Oliver Clark's Journal of Events Occurring during the Month of March, 1864, and during $h$ is Escape from Richmond to the Federal amy lines in North Central Virginia." However, scribbled in lead pencil on a neighboring page, the author found a quotation from Whitman's Song of the Banner at Daybreak, certain words of which lent thenselves more readily to a purpose of title than did the somewhat awkward designation Oliver Clark has inscribed.

Mr. Kantor also gives the quotation from Witman: 
I'Il weave the chord and twine in,

Man's desire and babe's desire - I'll twine them in, I'Il put in life;...

(As one carrying a symbol and menace far into the future,

Crying with trumpet voice, Arouse and Beware!

Beware and arouse!)

The novel is divided into three books whose titles are also taken from Witman -- "Babe's Desire," MLan's Desire," and "The Symbol and the Meñace."

As for the characters there are the three central characters already referred to and several minor ones. The central characters are Oliver Clarl, Prentice Barstow, and Naomi Kincaid. OIiver Clark is an educated Yankee of the First New Jersey Cavalry. He telis the story, and we are left with the impression that he will marry Naomi Kincaid. Prentice Barstow is an une ducated Yanke whose home was Iowe and who belonged to the Sixth Wisconsin Volunteer Infantry. He helps Clark to escape from Belle Island, and, although he wants to marry Naomi, he, in the end, sacrifices his own Iife in order that Clark and Naomi may reach the Inion Iines in safety. Naomi Kincaid is a Southem girl about twenty years old. She has been educated infomally by a talented but imprectical father who taught music and French and who captured butterflies and made trays and the like with their wings. Naomi is a strong character throughout the story. The minor charac- 
ters may be mentioned briefly. There is Colonel Stanislas Mokranowski, the Confederate officer from whom Naomi escaped. There is a raider, bent on crime, who is murdered by Barstow as he enters a house where the three refugees are taking shelter. There are the Home Guards composed of careless, thoughtless, inefficient young boys and somewhat more efficient older men. There is Henry Carpenter, a Confederate, who releases the refugees because Barstow has avenged the crime comilted in his home. There is Mr. Vestry, a man who helps Inion prisoners or sympathizers to escape to the Indereround Railroad. The other characters are: Johnson Tillingbee and his wife Entreaty, Confederates, who, nevertheless, help Clark, Barstow, and Naomi; Deaton Jones, a coward hiding from the war, who also helps the refugees; Cncle Deaton, a man ins ane as a result of his life in a Federal prison; and a negro slave called Yellow Boy, who tries to poison the refugees and does poison Barstow.

The plot of Arouse and Beware is briefly this: Clark and Barstow escape from Belle Island Prison and start their jourmey to the Inion lines. Almost at once they meet Naomi, who is also fleeing from Richmond. The three go on together. That is the first book, "Babe's Desire." The desire was simply for safety. Book II, 
"Man's Desire," shows that as safety becomes more certain a desire to marry Naomi arises in both men. She skillfully preserves peace, however, by a strong, impersonal, and impartial attitude toward her two companions. In Book III, "The Symbol and the Menace," Barstow decides that Clark is the better match for Naomi, and, when a cris is arises, he secrifices his own life to let liaomi and Clark complete their attempted escape successfully.

In this novel $\mathrm{Mr}$. Kantor interprets the war by describing with psychological realism, the experiences of three central characteri, by bringing into these experiences a Eroup of minor characters who represent phases of the war almost hidden behind the dominant issues of the conflict, and by commenting directly on the war. The first two factors in Mr. Kantor's interpretation have been given. His direct comments, spoken by oliver clark, who tells the entire story, are these:

This observation refers to a seemingly uncalled for cheerfulness on the part of the refugees.

I could feel little surprise at our sudden ignoring of the recent past, the uneasy present, and above aII the dark channel of the future. For I had ridden two years under Colonel Sir Percy Syndham, and I had seen whole troops of boys, their throats caked with dust, and bodies racked by the sharp sob of fighting. I had seen them torn and bloodied, covering their brothers and friends with fresh dirt, and going off within the hour to quarrel heartily over scraps of currency in $a$ 
Bluff game, or to pool their resources for brandy-andpeaches at the sutler's.

It is this fearful resiliency of the human soul, this rebounding ability to climb out of the grave and play marbles among the headstones, that gives to war its ghastly permanence, and the certainty that we shall see more people willing for war in years to come.7

The following paragraphs refer to their seeing an old man hopelessly insane as a result of mistreatment in a Federal prison.

Haomi felt only the acid of pity and revulsion, which beset her so that she could hardly speak for hours, and Berstow was angry at what he considered a political falsehood told against the Federals. But I found some grim strength in contemplating the fact that all the sins of a war are not visited by one side upon the other. Mankind as a whole, irrespective of army, is responsible for their instigation.

This is a knowledge not fit to be contained in any polite philosophy; . . .8

When the three Yankees are befriended by a Confederate soldier who had been injured too badly to permit him to fight, Clark says: "I wondered whether the same childishness which made men in mass to be enemies, and men sinEly to be valued a friends, would persist when the years lay like thick sod above us all."9

Mr. Kantor, in Arouse and Beware (1936) says that,

7 M. Kantor, Arouse and Beware (New York: CowardMcCann, Inc., 1936), p.67.

8 Ibid., p. 269 . 
human neture beine whet it is, we will always have wars.

In Royce Brier's Boy in Blue (1937) the war is explained as a money war, cs a war between the sluve system and the industrial system.

Boyce Brier wes born in River Falls, wiscuns in, in 1896. He dedicated Boy in Blue to his father, Warren Judson Brier (1850-1928), ع vell know Visconsin educator. Mr. Royce Srier spent three years in viting his Civil War notel. He made two trips to the Tennessee battlefields, and walked over the many miles on the Chickamanga field followed by Robert Thane, his central character in the nowel. 10

The theme of Boy in Blue (1937) is the effect of the war on Robert Thane, an ignoront Indiana farmboy. The novel beeins after the Battle of Menassas and ends before the close of the war. Eighteen-yesr-old Robert Thene is disappointed in his first love affair and joins

\footnotetext{
Ibid., pp. 227-228.

$10 \mathrm{Mr}$. Royce Brier was bom on April 18, 1896, and was educated in public schools and at the Lniversity of Wisconsin. He was first employed by the San Francisco Chronicle. In 1934 he won the Pulitzer Prize for reportine for his coverace of the Iynching of Holmes and Thurmona, Prooke Hart kidnappers. -- Biographical facts from book cover of the D. Anpleton Century Comvany edition of Boy in Blue and from an item in the liew York Times, lay 8, 3.934 .
} 
the 257th Indiana Infantry, hoping to be killed. He is wounded in a battle in Tennessee and is nursed by an educated Southerm girl who awakens in him a desire to learn to speli and a desire to read tine masterpieces of literature. A wholesone love, unlike the first one, grows between them. After a time Robert returns to the army and is again wounded, this time so severely that the doctor says it will be necessary to remove one foot. At first, Ann Countisis, the Southem girl, $x \in$ fuses to let it be done; she had heard that many legs vere being cut off without sufficient cause. Having taken for granted that Ann was Robert's wife, the doctors respect her wishes. Then, suddenly, she withdraws her objections, Robert consents, and the operation is performed. Robert's consolation is that he and Ann will be married as soon as it is possible, and Ann's consolation is that wi thout his foot the army could never take him away from her again.

This wartime love story is told against a realistic background of army life and of life in the rurel districts of Indiana where Robert lived. Mr. Brier creates a wartime atmosphere by conversations and by descriptions of dances, of parades, of railroad yards wen soldiers are departing or retuming, of the telegraph office after the rumor of a battle has reached the people, and of the utter 
misery of the soldiers on long marches, in battles, and in inadequate shelters. This background is peopled by minor characters who supply a variety of attitudes toward the war. Robert's father, an ignorent farmer and a stern believer in the Bible, is an abolitionist, a firm Enionist, and as good a man as he knows how to be. Iis brother, Gideon Thane, a man of broader experience, is so far from being a good Inion ist that he is suspected of being a Coppe rhead. These two men give us two explanations of the war from a stay-at-home angle. John Thane believes the war to be a holy war against slavery; Gideon calls it a money war.

"Who's to fault?" John asks Gideon

"INobody. It's just two ways of I ife, and comes the tire, one has to grind the other in the dust. That's all any war ever was. . ." He paused, thinking he had been temperate in his remarks. Two ways of life -- who could deny that? But there was an enlarged pulse in John Thane's thick neck.

He had truly been lying in wait for Gideon. "I know them milk-sop words. Weak as water-gruel, say I. All wars! You say a war to put down human slavery is twin to a war to give some parysite King nore mo ney? You come to ny house and tell me that?"

- Oh, I grant you it's a more popular war than some, John, so'lI be accounted more righteous than some. As for human slavery, there's too few who hold with you on that, to make this war. You'll concede there's a sight more ready to fieht with precious leetle consam for Rastus and mighty big consam for keeping this Union geared to their way of life. 
"The point I make is that all wars, you b'il 'em right down are money wars..."

"If you wa'n't my own blood, you'd git -- I wouldn't nary suffer you to set there -- talkin' blasphemy - - talkin' human slavery's a money matter -- God in His wisdom spares you, Gid -- He don't strike you dead -- He's a mers'ful God . . ." John Thane lifted his head, he closed his eyes. 21

John and Gideon thane are the most important minor characters in the rural Indiana district. Outstanding among the minor characters Robert meets in the Army is Maury Coldiron. Coldiron is "nearing twenty-six. . . had been a tramp printer . . had worked on the New York Tribune and the Herald . . had talked with Greeley and Bennett and . . had seen Laura Keene in a carriage."12 Coldiron's remarks about the war usually resemble this one: "A man could write a whole novel about Shiloh if he set himself to it, a novel of stupiaity ana Irustration." 13

Robert's opinions of the war, in contrast to his father's, are something like this:

Holy war! Who thought so? No one in the 157 th or the Fourth Brigade or the Army. No. The country had got itself into a peck of trouble and no one knew how to get out of it. . . What man was there in Company "K" who would lift a finger for a damed nigger?

II Royce Brier, Boy in Blue (New York: D. Appleton Century Company, Inc., 1937$), \overline{p p} \cdot 6-7$.

12 Ibid., p. 78.

13 Ibid., p. 79 . 
Who thought Generals won wars? Why the big tubs sat in offices or fine houses, or in their ow railroad cars, drinking whisky punch, smokine cigars and looking at maps. 14

Other than this opinion, the war is to Robert one long, continuous stretch of rain, cold, hunger, pain, and weariness -- all over something, whatever it is, that is nonsense.

Robert's attitude toward the war, together with the panoramic picture which Boy in Blue (1937) presents, is Royce Brier's interpretation of the American Civil Vlar. The last of the Forthern interpretations is Action at Aquila (1938) by Hervey Allen. Mr. Allen has had actual war experience. In 1916 he was a second lieu tenant in the Pennsylvania Infantry on the Mexican Border, and in 1917 and 1918 he was a First Lieutenant in the llith Infantry, 28 th Division, A.E.F. He was seriously wounded during August, 1918, and was s ent back to America.15
14 Ibid., pp. 85-86.
I5 Mr. Allen was born in Pitts burgh, Pennsylvania, December 8, 1389, and received his elementary education in that city. He attended the Inited States Naval Academy at Annapolis in 1910 and 1911 , but he resigned without graduating to enter the lniversity of Pittsburgh whe re he received a B.S. in Economics in 1915. Since the World War he has attended Harvard, has taught Bnglish in a Charleston, South Carolina, high school and at Columbia Tniversity, and has lectured at Vassar College. He has been active in awakening an interest in poetry throughout the South. Facts from Living Authors. 
The theme of Action at Aquila is that war will be etermal, that human beings will never remember the horrors of war long enough to prevent another war. Mr. Allen develops his theme by interpreting the American Civil War from the point of $v$ iew of a central character who remembers the Mexican War, is a Colonel in the Civil war, and lives to see the outbreak of the Spanish American War. The central character is Colonel Wathaniel Franklin of the Sixth Pennsylvania Cavalry. Colonel Franklin, according to Mr. Allen, is not typical of his period. He looks at the war as a dis interested observer might have looked at it, although he is a soldier.

Mr. Allen begins with the autumn of 1864 in recording Colonel Franklin's wartime experiences. The experiences include relations with the people of Philadelphia, a parade in honor of the State Fencibles who were leaving for the Soutr, a visit to Buchanan, the burning of a Confederate's home, actual fighting, and hospital iffe. At the beginning of Action at Aquila (1938) Colonel Frankl in is riding on ho rseback from Philadelphia back to $h$ is army in Virginia. His first and only furlough is nearing its end. We learn what has happened before his furlough from $h$ is reverie which covers 130 pages of the novel. Then we follow him to the end of the war. The last chapter jumps 
about thirty years and brings the novel to an end with the outbreak of the Spanish-American War and with the Colonel's death.

The war is interpreted, with the familiar bcokEround, as a necessary meens to a necessary end -- the preservation of the inion. However, the war is not interpreted as anything that should inspire flag waving and patriotic speeches. Colonel Franklin knows that the horror of the war will be forgotten, that "how men felt" will be forgotten, and that the ame stupid flag waving will characterize another war. Colonel Franisl in is old en ough to know that the horror of the Mexican Far faded, and he lives to see the horror of the Civil War fade, too. Just before he dies, he sees flag waving again at the outbreak of the Spanish-American War. Mr. Allen seems to say that no war will be horrible enough to teach human beings a lasting lesson of peace. Mr. Kontor said the same thing in one statement, 16 al though he did not make it the theme of his novel as Mr. Alle $\mathrm{n}$ has done.

Each of these Ior therm interpretations of the Civil War places central characters, who are soldiers or have been close to actual warfare and care little about the

\footnotetext{
16 See pages 135 and 136 of this thesis.
} 
issues of the war, against a panoramic background peopled by characters who indicate that there was intense partisanship in the country al though it was not shared by the soldiers. The greater part of each novel dwells on a very disagreeable, realistic, unromantic picture of the war. There is a befinning of the economic interpretation which explains the war as a conflict between two ways of living. The Southem fiction e mpasizes this economic explanation still more than the Northern by repeatedly interpreting the war as some thing which destroyed the Southern civilization. The re are at least three attitudes toward this destruction. The novelists accept it as a fact, consider it a misfortune, or show the kind of people who were not defeated when the world around them was destroyed.

The earliest Southem novel is Marching on (1927) by James Boyd. Mrr. Boyd was born on July 2, 1888, in Dauphin County, Pennsylvania, but he moved to North Carolina, the home of his earlier ancestors, when he was thirteen years old.17 The principal scene of Warching on (I927) is North Carolina.

The theme of the novel is the change in the social

17 Biographical facts from Iiving Authors. 
and economic conditions of the planter aristocracy and the white farmers, a change which was brought about in the South by the Civil War. The title refers literally to the seemingly endless marching of one corpany of soldiers, but I think thet it refers also to the marching of the old South through the Civil War to a change in social and economic conditions. To develop this theme Boyd chose for ilis hero the son of a non-slave-owing Forth Carolina farmer and for his hero ine the daughter of a weal thy planter. At the beginning of the story the hero is presumptuous in areaming of marrying the heroine. James Fraser, the hero, comes of a good family, but wi thout money they cannot buy slaves and without slaves they cannot make a great deal of money. Therefore, the education and luxurious home necessary to high social standing are beyond him. Nevertheless he falls in love with the olanter's daughter, leaves the farm to become a railroad mechanic, retums to enl ist in the amy, fights, spends three years in prison, retums home ill, recovers, and marries the planter's daughter instead of going to fire a last shot at the Yankees. By 1865 the economic superiority of the planter class was gone. The social superiority was almost wiped out because the education of the once weal thy Southerners was not adequate to enable them to 
make money in the changed Soutil. Janes Fraser's experience as a railroad mechanic was more valuable. The war had brought about the change.

The minor characters, chosen from many walks of Iife, give the usual panoramic beckground. There are planters, non-slave owning Southern famers, Crackers, professional men, politicians, slaves, the city workine class, and soldiers.

James Boyd's interpretation of the effect of the war is Eiven by his theme. His explanation of its cause seems to he the Southerners' hatred of Yankees. The minor characters pile up this evidence and send James Fraser to War hating Yankees. Their op inions are expressed thus: Tom Magruder, one of is neighbors, said:

Why, doe my cats, if these Abolitionists ain't the me anest kino of scoun'rels. . . Suppose I tolied one of your shoats up in to my logpen and then wouldn't give him back. . Y You'd say I was a tilief, voulan't you? 18

Ar old planter said:

I expect I'II be ahead of you in wixine into the fracas. But not because I expect it to benefit the South -- In fact, it will Iikely ruin her -- but because I consider Yankees sanctimonious, illbred, meddlesome, mean, and chicken-livered, and would be mighty glad of a chance to show my feelings. . . .

I'm not fooled like most folls by talk of prosperi-

\footnotetext{
18 J. Boyd, Marching on (New York: C. Scribner's Sons, 1927), p. 79 .
} 
ty and Southern rights. . . I just plumb hate the Yankees. 1.9

In Wilmington, ivorth Carolina, the mechanics in the railroad yard told with contempt stories of Yanrees' close dealing in money matters. The boss nechanic concluded with this renark:

"They's one way to get ahead of a Yankee." The others i is tened vith respectful attention. The boss mechanic closed a big, white, greesy fist. "Show him that. He'll quit his foolishness quick enough." They nodded Erave anoroval. 20

Mr. and. Mrs. Torker who kept the boarding house where Jomes stayed in vilmington hated the Yankees. Major Cassius Pettibone, a former clerk of the court, explained how the Yankee tariff and Yankee manufacturers made roney on Southemers' cotton. 21 James Fraser's hatred of the Yankees was built up by the boy's observations, experiences, and associations with verious clesses of people in North Carolina.

In describine actual varfare, Mr. Boyd is realistic and unromantic. His titie, "Warchine on," as I have said, refers literally to the secmingly endess marcine of James Fraser's company. There is nothing glanorous in
19 Ibia., .177 .
20 Ibid., pn. 1.69-I70.
21 Ibia., p. 161 
any of Mr. Boyd's descriptions of the war.

Marching on (1927) interprets the war realistical$1 \mathrm{y}$, from the point of view of an ordinary soldier, and with a panoramic backeround. The thing which made the South willing to fight was, according to this novel, hatred for the Yankees. The effect of the war, accordine to Boyd, vas a levelling of social classes in the South. James Boyd's final verdict in his interpretation of the Civil War seems to be, "It happened. It had to be. But, there was nothing real to fight for." At least that is James Fraser's opinion. Slavery and states' rights vere not worth the fight, and Yankees personally were not what he thought they were. At the end of the var James Fraser does not hate Yankees.

In The Wave (1929) Evelyn Scott calls the war an unreasoning force, as Mr. Benet did. However, Evelyn Scott substitutes mob psychology for John Brown's body in explainine the unreasoning force which carries everyone wi th it in a manner comparable to the action of a real wave. Tre novel is a series of osycholocical an alyses of human beines of all classes in both North and South, becinning with the excitement over Fort Sumter and ending with the return of the solaiers after the war. Evelyn Scott, who was born in 1893 in Clerksville, 
Tennessee, who spent her early years in New Orleans, and who has since Iived in foreign countries, spent two years in collecting material for The Wave (1929). She Eives the following explanation of her title:

Whatever the philosophy of an actor in a wer, he must constentIy be convinced of his feebleness when atterpting to move in an emotional direction contrary to that of the mess. This propulsion of the individual by a power that is not accountable to reason is very obviously like the action of a wave.22

On a flyleaf at the beginning of The lave (1929)

there is this quotation concemine Eenuine weves:

The water of the ocean is never still. It is blown into waves by the wind, it rises and $f$ alls with the tides. . . The waves travel in some definite direction, but a cork throm into the water does not travel with the waves. It moves up and down, to and $f r o$, but unless it is blown by the wind or carried by a current it retums to the same position with each wave and does not permanently leave its place. . . In deep water the motion of the particle at the surface (of the wave) is nearly circular. At the crest the movenent of the particle is forward, at the middle of the rinder slope it is downward, in the trough backward, and at the middle of the front slope upward . . Taves have very Iittle effect excepting near the surface - . When a wave approaches a shelving sho re it keeps its form as a wave until it is near the $l$ and and then the top faIIs forward and the wave breaks. This is due in part to the fact that the wave travels more slowly as the weter becomes shallower... When the water is deep close up to the shore, the waves, if they break at aII. - . appear to throw themselves against the cliff. . . and the vater cashes... some times to a very great height. Physical Geokraphy, by Philip Lake, M.A.

\section{Biographical facts from Iiving Authors.}


The theme of the novel is the effect of the American Civil War on the people who experienced it. The characters include soldiers, stay-at-homes, slaves, free neEroes, historical leaders, rich people, poor people, and, in short, just about every type of person in this country in the $1860^{\prime} \mathrm{s}$. There are more than sixty separate narratives \&rouped into twenty chapters. The plots of the narratives, each of wich has its om characters, deal with almost as many subjects as there are narratives. Except for the chronological order in which references to war are made, the reader would feel that the novel was getting nowhere. There is no development, no change, in the experiences of the people. I think that Miss Scott's purpose was to show the people being tossed about by the war, but not progressing in any direction. The people are like the cork in the waves, which the quotation from the geography refers to.

One story shows the effect of the war on Janie, a nine-year-old Virginia boy, the oldest child in a family of seven. Because Janie was a problem to $h$ is mother, he was spending a year in Charleston with $h$ is aunt and uncle. The war had given Jamie a craving for excitement and a yeaming to be something bie. One morning he and a little friend pretended that they were fighting against Yankees. 
They were near the buming Charleston cotton sheds which General Hardee had ordered destroyed. That Jamie had been forbiden to go there did not disturb him. He liked the scene.

Jamie was in rare spirits. He had long felt irritation in being relegated to the fringes of the war, and now, in defiance of hils mournful, careful mother, was elatedily convinced that he had found the thick of it. 23

The very fact thet he was doing wrong and would be punished made him more reckless. Finding some kegs of powder by the ralload station, Jamie examined them curiously.

He thought:

And this was the stuff that had made the war. Fe felt it voluptuously upon $h$ is finger. This was the magic that had killed is father. Happy, fearful in his self-engagement, he glanced doubtiuliy at it. 24

Then an idea came to $\mathrm{h} i \mathrm{~m}$ :

Quick, Ted, I'm gonta make a trail of this to where that cotton's burnin'. Come on. Get a handful. I bet when those Yankee Eunboats hear the rumpus we make, they'll go ste amin'.25

The excitement grew, and they carried handful after hand-

ful of the powder. Ted was fearful but--

Jamie didn't reflect, would not reflect. Powder, powder, more and more powder. It would be like

23 E. Scott, The Wave (New Vork: The Iiterary Guild of America, $1929, \overline{p \cdot} 460$.

24 Ibid., p. 464

25 Ibid., p. 465 . 
Gettysbure, he thought. He had heara $h$ is uncle, wajor Lawrence, extol that battle. Or, We'II make more noise than the Confederate arry at Hanassas did!26

Janie thought that if his uncle wanted to punish kim this time there would be some thing big to punish hin for.

There was a hunger in $h$ in to be something, to do something. Grown-ups had all the fun in the var. If they expected hin not to care what happened, tiney shouldn't talk so much. Ted said, "What if a lot of people got hurt, Jamie?" and considered himselt, abashedly. Jamie answered, $h$ is eyes Erowing laree and hard with wonder, "Y'all oughta be a Yankee, Ted. If you do your duty and have sho' 'hough spunk you don't need to think. I wouldn't be in any old army if I couldn't be the biggest $g$ eneral. "27

Finally the powder caught fire, but there was no explosion, only a drizzling sound. Jamie vas depressed. And, then, the roar came. Jamie's dis appointment changed to fright, to joy, and finally to a belief that after this glory life would not be worth Iiving.

The reverberations, coming so instantly upon a flat submission to dis appointment, left both boys densely uncorprehending. Jamie pressed flat to a fence, sensed himself rigid against inanimate tremings. His blue Eyes, stern, as he received a blow, filled quickly with excited tears. His heart le aped like a mad thing soringing from his chest. He was 'scared to death.' Then, under a flood of rapid feeling, he felt his accomplishment. "We did it. We did it. I did the most, Ted. Goody, goody! I'll bet the depot's bumin' too."

Nothing comparable had ever occurred before. It was an exhausting ecstasy. Mystically, the glory drew
26 Ibid., p. 465. 
him. Bruising himself on the walls, he ran swiftiy, to be nearer, nearer. He did not quite dare reach the place. No, he would rather go the other way. He vanted to flee to a remoteness from all the dull sounds, where nobody would ever find $k$ im. After this, life would hardy be worth living. He could think of almost nothing more to do with it. Everything in the world seemed to have happened in a minute. 28

In this manner Evelyn scott shows all manner of people being tossed by the "wave."

Stark Young, in So Red the Rose (1934), re turns to the economic interpretation of the war. He feels that the Civil War destroyed a desirable civilization. Stark Young, writer, poet, teacher, traveler, borm in Como, Mississippi, on October 1I, 1881, has in his make-up a love of the South and of the aristocratic civilization of the old South. This love was probably fostered by his education at the Lniversity of Mississippi, which he entered when he was I ittle more than fourteen because the school at home had been closed. The faculty of the University of lisisissippi was trien composed of gentlenen of the old south, impoverished by the Civil War. 29

So Red the Rose (1934) is a sympathetic picture of the effects of the Civil War on the south and particularly on the people of two Mississip i plantations. Malcoln
28 Ibid., p. 467
29 Biographical facts from Iiving Authors. 
Bedford, the naster of Portobello plantation, and Fugh McGehee, the master of Montrose plantation, are brothersin-law, each having married the other's sister. Lalcolm's wife had died chilaless, however, and he had married again. So harmoniously did the second wife fit into the family that she named her first little girl for her dead predecessor. The hero of the story is Duncan Bedford, twentyone years old and at the Cniversity of Virginia when the story begins. The heroine is Julia Valette Sorerville, the child of a friend in New Orleans. Duncan enlists in the Southern army, fights, is imprisoned, and finally returns to marry Valette. Malcolm goes to war, returns with typhoid fever, and dies. Hugh McGehee and his family fare still worse in the war. Their home is bumed, their son is killed, and their daughter's sweetheart is killed. Hugh MoGehee, however, survives the conflict and it is through him and his conversations with Duncan thet lir. Young interprets the extemal effects of the war.

In the beginning Hugh McGehe was a slave-owner, not because he wanted to be, but because he was and did not know what to do about it. He favored the Inion before the war, but in the war he suported the South. He recognized the war as a conflict betveen industrialism and the planter civilization. 
-. He saw the war only as in the line that had begun in England with the Industrial Revolution and was moving onward toward its eak. This planter civilization had been in the way of it, and had to be destroyed. Just that. 30

But Hugh McGehee was not certain of the merits of industrialism. He believed that slavery was a necessary evil, a price to be paid for a civilization worth havine:

". Have you noticed the parallel betveen the cases for democracy and for slavery? Or, perhaps you judge as Horatio says, "twere to consider too curiously to consider so."

"What, Incle?" Duncen said.

"ell, this: denocracy, a good theory, a great human right, which works out none too well; slavery, a bad theory, a great humon wrone, which works out none too badly. I endorsed democracy, I condemned slavery; and here I am wi th my house bumed down and my colored people free, deceived with false promises, mixed up and robbed. Mr. Mack and his crew [carpet bagecrs] won't consume ine, but that's only because he hasn't brains enough and hasn't enough life behind him. If I were nean, I reckon, I'd have to laugh about that: tinese men just haven't enough Iife behind them to match me. I me an by 'Iife' tradition, forefathers and a system of living. Don't laugh at me for a professor or some cormon editor; but these people make you want to explain things you'd always taken for granted. Then you begin to explain things you've always taken for granted, you've already begun to lose them. Still I have to I augh. It's as if I stood on the ground and they didn't." 31

Hugh McGehee admits that the planters are out of the way for a time, but he does not think that the South has been

30 Stark Young, So Red the Rose (New York: Scribner, 1934), p. 396 .

31 Ibid., pp . 394-395. 
helped.

"So they got us out of the way," he went on to Druncan, "for a time, till they break their own necks. I'm not saying we had the most desirable society, or that men should go back to it; I'm on ly say ing give them three generations now and they'll have ashes in their mouths. At least we had some degree of peace and stability for a wile; but that must not be endured, no. Now ours is demolished, we'll see where the other will end, and the society it develops, if it develops anything that can be called a society."132

Mr. Young interprets the war as a step in the Industrial Revolution, but with no optinism as to its results.

Margaret Mitchell deals both with the things which the war destroyed and with the people who survived. Miss Mitchell was bom and still lives in Atlanta, Georgia, whe re the scene of Gone with the Vind (1936) is Iaid. Concerning the choice of the $\mathrm{C} i v i l$ war as a subject for fiction, Miss Mitchell says:

"I chose the Civil War period to write about because I vas raised on it. As a child I listened for hours on Sunday afternoons to the horror of Sherman's approach, his final arrival and the burning and looting, and the roads to Macon. And I heard about Reconstruction. In fact, I heard every thing except that the confederates lost the war. When I was ten years old, it was a violent shock to leam that General Lee had been licked. And I thought it had all happened just a few years before I was born." 133

\footnotetext{
32 Ibid.,

33 Margaret Mitchell, "Marearet Mitchell," Wilson
} Bulletin, $11: 12$, September, 1936. 
Both IIiss Mitche 1 's parents were authorities on Southem history and natives of Atlanta. Her grandparents had cotton plantations in the vicinity of Atlanta before the tow was built. 34

The theme of Gone with the Wind is, according to the anthor, that of survival. She adds:

". . What was it that made some of our Southerm people able to come through a War, a Reconstruction, and a complete wrecking of the social and economic sys tem? I don't know. I only know that the survivors used to call that quality 'gumption.' So I wrote about the peorle who had gumption and the people who didn't." 35

The title of the novel refers to the southem social system; the "wind" was the Civil War.

The central character is Scarlett OHara of Tara Plantation, the belle of the county in which she lived, headstrong, spoiled, and selfish. The one thing she realIy loved was Tara, the glantation, and for it she lied, slaved, and married twice. Opoosite Scarlett is Rhett Butler, a blockade runner, who in his way of living is as unscrupulous as Scarlett. He comes through the war with money, and for that reason Scarlett marries $h$ im, the third husband whom she does not love. Her first husband, a boy

34 Biographical facts are from the article in the Wilson Bulletin, September, 1936, cited in footnote 33 .

35 Mitchell, 10c. sit. 
who two months later was killed in the war, she married on the rebound after losing the nan she wanted to another girl. The second and third husbands she married for money, although when it was too late she decided that she loved Rhett Butler. The other characters are the conventional Southerm ladies and gentlemen, for whom tine world died at Appomattox.

Miss Mitchell interprets the war as a wind which swept away the Old South. The people who survived were the people who changed. 36

Clifford Dowdey, in Bugles Blow Io Hore (1937), also has for his theme the demoralizing and wrecking of the South by the Civil War. Mr. Dowdey, who was born in Richmond, Virginia, on January 23, 1904, has made historical study his hobhy. He received his college education at Columbia Iniversity and has been employed in newspaper

36 The following item conceming Gone with the Wind is interesting :

To most of its C. S. readers, Gone With the Wind is straight his torical romance. Foreigne rs Iike it almost as much, but judge it differently. How published in 14 countries, with sales reachine 184,000 in England, 6,000 in Hungary, 4,750 in Chile, it has made its biggest sensation outside the $\tau$. S. in Nazi Germany, which has bought 134,000 copies. Nazi highbrows, calling it irresistible, found it an attack on "plundering mercantile Yankee casitalism" and on democracy. Said Das Innere Reich, leading Nazi li terary joumal, "We see the fall and death of the old aristocrats, the rise of the parvenus, the uncultured, and 
wo rlt. 37

BuEles BIow lio lore (1937) starts on Secession light and ends with Lee's surrender. The scene is Richond. On Secession Wight lildred Wade, the heroine and a kichmond aristocrat, sees and is attracted by Brose Kirby, her father's clerk who is definitely below her socially. Even in his own cless Brose is known as an uncontrollable young man, as "a black "un." But the excitement of the war was in Mildred and all the entreaties of her family could not stop her from longing to see Brose again. When her father left for the war, she promised him that as long as he lived she would not see Brose; but her father was killed, and in December, 1862, Brose was sent home wounded. From then on mildred neither hesitated nor tried to hide her love for Brose. She explains:

". . It was different when people's lives went on in security. Then they were bound to family ties and duties that stretched beck into the past. Ilow we have no past. As you said, we have only today."38

the Negroes, hitherto wisely controllea." Her Gerran publishers send Margaret Mitchell regular royalty statements but pay her no cash. -- Time, $33: 91$, Aoril 24, 1939 .

37 Biographical facts from Durward Howes, editor, America's Young Men of 1938-1939 (Los Anceles, Califormia: Americen Publicetions, Inc., 1938).

38 Clifford Dowdey, Bugles Blow No More (Boston: Little, Brown and Company, 1.937), p. 220 . 
After a time Mildred and Brose were married, and three mon ths later their baby was borm and died. At the end of the war they have nothing except their love and a doubtful courage to go on living. This love story is accompanied by a realistic picture of wartimes in Richmond.

Jone Shall Look Back (1937) by Caroline Duff-Gordon (Mirs. Allen Tate), another picture of the destruction of the Old South, resembles So Red the Rose (1934) more than any other of these novels. Mrs. Tate, born on October 6 , 1895, has spent most of her Iife in Clarksville, Tennessee, where she now I ives wi th her husband on land that has been in her family for generations. She is, on both siaes, originally from Virginia stock. Her people have been planters and country lawyers since early colonial days. Although in Clarksville she finds the atmosphere and much material for her best work, she has done newspeper work in New York and has spent several years in France. 39

The theme of None Shall Look Back (1937) is the death of the civilization of the 01d South and the birth of a hitherto despised industrial civilization. The title

39 Biographical facts fron book cover of Charles Scribner's Sons 1937 edition of Ione Shall Look Back and from Stanley J. Kunitz, editor, "Caroline Gordon," Wilson Bulletin, $12: 10$, September, 1937 . 
implies that the surviving Southerners will go on into the new civilization without looking back to the oId. There is this quotation at the beginning of the book:

Stand, stand, shall they cry; but none shall look back.

INahum, Chapter II, V. 8 .

The home of the heroine is in Kentucky, on a tobacco plantation. The $s$ tory follows the war in the western part of the South. The battles of Donaldson and Chickamauga and the exploits of Forrest are described.

The central characters are Rives Allard, of Georgia, a cousin of the Kentuciry Allards and a scout under Forrest and Iucy Churchill, an orphan grand-daughter of Fontaine Allard, the Kentucky tobacco planter. The minor characters are relatives and amy men.

The story begins with a birthday dinnex in honor of Fontaine Allard's sixty-fifth birthday. Ned, his son, and two cousins, George Rowan and Rives Allard, come home from school to go to war. The conversation inevitably turns to the war, and al though the young people try to trest the subject lightly, the older people are worried. Typical opinions are expressed:

Captain Leffingwell: " $\cdot \dot{-} \cdot$ "Wen the country's at war a man's got to take sides."

Fontaine Allard: ".. A man's got to take sides.. At least he's got to take a stand. But 
these people 'way dovm south are different from us. I was dow there in 155 visiting Cousin Joe. I often think of it. . . Why there was one fellow, old Men Trotter Simpson's son, raised right here in To da County, Kentucky, on hog and hominy, like all the Simpsons. Why, that fellow -- I made Joe drive me in to see his place one day just out of curiosity. He was living in a mansion with six thous and acres of good cotton land, waited on hand and foot by negroes and all bought with two years' cotton crops Joe told me."

Captain Leffingwell nodded. "It's a rich country. I saw'er plowing in the fields and water solashing high as a mule's knee. Can't cake the land they tell me. Too fat."

"That's it," old Mr. McLean said testily. "It's too rich. How this country, we been a long time building it up. Those fellows down there got rich too quick and it's gone to their heads. If somebody don't hold them down they'll ruin the country."

Leffingwell: "It don't matter how rich they are or What they raise They're all fighting for one thing.
treedom. - $40^{\circ}$

Then, through Rives' thoughts we see hin at school, escaping from the dormitories after the iights were out to $g 0$ to hear Charley Button tell the boys how to enlist as Rangers. Colonel Forrest had pronised to take Rives, George, and

Ned later. Then the boys came home. After listening to the conversations of the older men:

All this talk about slevery, the tariff, the Hartford Convention of 1815 when the east had wanted to secede from the Inion, even the discussions of the methods of warfare confused him, took away from the exaltation he had felt at the thought of going to war.

40 Caroline Duff-Gordon, None Shall Look Back (New York: Charles Scribner's Sons, (1937), pp. 8-11. 
With an effort he found his way back to that feeling. Jo, it was not a question of slavery -- his own family, for instance, did not think it right to own slaves -. and he did not understand all this business about the tariff. He thought with a kind of obstinateness that it was really just as that Colonel Forrest said. Our country had been invaded -- it did not much matter on what grounds the invader had cone. . . The country had been invaded. Men were wantea for her defense. He was glad to go. 41

Rives goes to war and we follow a realistic account of his experiences. Many Southerm leaders figure in the account. In addition to the amy Iife, there is also a realistic picture of the lives of stay-at-homes. We follow the love story of Rives and Iucy who marry and then are seperated by Rives' death at the end of the novel. The survivors must $E O$ on in a ruined world -- "NOHE SHIII IOOK $9 . \mathrm{CK} . "$ William Faulkner, in The Lnvanquished (1938), tells about the destruction of the Southern civilization, but, like Margaret Mitchell, he also tells about the survivors. Mr. Faulkner was bo $m$ in New Albany, Iississippi, september 25,1897 . He receivea $h$ is elementary and $h i g h$ school education in Oxford, Mississippi, and from 1919 to 1921 attended the Iniversity of Mississipi 1.42

This background vell prepared him to write a series of stories which interpret the Civil var from the point of

\footnotetext{
41 Ibid. , p. 25

42 Biographical fects from Who's Who in America, 1936-1937.
} 
view of Mississippi plantation people. The theme of the novel is the unfaltering perseverance and resourcefulness of these "unvanquished" Southerners, in dealing practically with the experiences of a war. The central character, Bayard Sartoris, a child of nine at the beginning of the novel, tells the story. Ringo is his negro, his bodyservant, and his constant companion. They are the same age. John Sartoris, Bayard's father, leads his own band of Confederate soldiers during the var, and, after the war attempts to estroy the Reconstruction govermment with the sword. He lives "by the sword" and dies "by the sword." Ringo's mother hed died et his birth, and her mother, Rosa Prilla d or Granny, became the mistress of the Sartoris plantation. When their hoxe is burned by Yankees, Gramy sets out in a wacon puIled by two mules to visit relatives in Memphis. She is accompanied by Bayara, Ringo, and tro other slaves. Just about all the baceare they take is a chest of silver. The rules, old Fundred and Tinney, the silver, and the two slaves were stolen or confiscated by Yanke soldiers. Granny, after a time, finds the comandine Eeneral and recuests her property: ne.

"Mayce you can describe thera," Colonel Dick said to

"I vill do it," Granny said. She didn't open her eyes. "The chest of silver tied with hemp rope. The 
rope was new. Two darkies, Ioosh and Fhiladelphy. The mules, Old Hundred and Tinney." 43

The request was misunderstood, and when the written order for the return of her proverty vas received, it read thus:

Fie ld Headquarters

...th Army Corps,

Department of Tennessee

Aucus $t$ 14, 1863.

To all Brigade, Regimental and Other Commenders: You will see that bearer is repossessed in full of the following property, to wit: Ten (10) chests tied with herno rope and conteining silver. One hundred ten (1I0) mules ceptured loos e ne ar Philadelphia in Mississippi. One hundred ten (110) Neeroes of both sexes belonging to and having strayed from the same locality.

You will further see that bearer is supplied with necessary food and forace to expedite passage to his destinetion.

By order of the Generel Comanding. 44

Granny received the full witten order and with that befinning carried on a racketeerine business in ules which succeeded wonderfully unt il it finelly ended in her death. Ringo and Bayard revence her deatin, but years later when Bayard's father is killed, Bayard does not kill the murderer. His father lived and died by the sword, but he hirself will not live that way.

\footnotetext{
43 villiam Faulkner, The Lnvanguished (New York: Random touse, 1938), p. I25.

44 Ibid., $p \cdot 12^{r}-128$.
} 
In $\mathrm{Mr}$. Faulkner's interpretation of Civil War ezperiences there is a generous amount of humor in connection with the cheracters of Granny and Ringo. Otherwise the re is the familiar picture of suffering and destruction together with a nicture of the changes wich had to take place in people's consciences if they survived.

The Fathers (1938), the latest Southem interpretation of the war, was written by Allen Tate, a poet and critic, born on November 19, 1899, in Clark County, Ientucky. 45 The Fathers deals with a caritalist and individualist, a person something I ike Faulner's Granny who is not defeated by the war. The story is told by Lacy Gore Buchen, who is a boy of fifteen in April, 1860, ena is Iiving with his fanily at Pleasant Fill, a Virginia plantation. His hero is his brother-in-law, George Fosey, the individualist. While of good stock oricinally, the Poseys hed fallen below the standards of the social code, and Susan Buchan's family, hefore the marriage, and Susan herself, after her marriage, regretted her choice. But, that old social order vas destroyed by the war and with it all the people who could not change. Georee Posey can 80 on in the changed world.

\footnotetext{
Biographical facts are from Who's tho in America, $1936-1937$.
} 
The story is, briefly, this: On the day before the funeral of Lacy Buchen's mather, George Posey rides off to tow instead of staring with his wife and her relatives as social decorur demanded that he should do. Ihrough Lacy's thoughts we see George at various times in the past refusing to conform to the menners of the times. Then, Lacy's father comes into the story, and the reader gatiners that he is neither a lover of slavery nor a believer in all the evils attributed to the system. In a passive way he is $a$ tnion man. Fovever, he does not want the secedine states suppressed by war. Major Buchan camot cresp the situatjon, but Ceorce Posey does. He ains control of the Buchen property, not to take it from them, but to save it for them. By wise business transactions as well as by blockade ruming, George Fosey comes through the war with money. However, George is so unlike Susan's femily that she finds it almost worse than death to be his wire. To prevent one of her brothers from marrying George's younger sister, Susan forces the sister into a convent. Then, Susan's hair tums white and she loses her nind. Iacy's father allows himself to be haned when a confession of loyalty to the cnion might have saved hir. At the end of the story George leaves the emy for misconduct, and Iacy goes on with the army to finish what his hero could not 
finish.

The title of the book refers to Georce Fosey's fatrer, whose brutality and viciousness had much to do with his son's individualism, and to Lacy Buchan's father and others like hir in the South, who could not deal practically with the problems facing them. These "fethers" are the basis of Mr. Tate's psychological and economic interpretation of the var. Perhaps there is an allusion intended to Ezekiel $18: 2$ :

- . The fathers have eaten sour grapes, and the children's teeth are set on edee. . . .

To sum up: The preceding period, 1900-1919, begen with historical romances which idealized the history of the civil War and ended with historical romances which pleed for wars to cease. This evident disillusiorment forms the connecting linl between that fiction and the fiction since 1920. Novelists again turned their attention to people instead of politics. From 1920 to 1939 the literary interest in the Civil War hes again been psycholotical. There are differences, however, between this period and that of Bierce and Crane. Naturalism and industrialism replaced the realism and sentimentalism of 
the earlier psycholocical period, and the outlook has been social rather than individual. This fiction interprets war as a part of nature. It interprets this particular war as a step in the Industrial Revolution, as the triumph of the machine civilization over the aEricultural civilization. 
CHAPTER V

CONCLLSIONS 


\section{CHAPTER V}

\section{CONCLTSIONS}

1. From my investigation of the interpretation of the American Civil War in American fiction, I have found that there have ceen primarily two types of interpretations, one political and the other psychological. These two types have al temated, one replacing the other arproximately every twenty years. Fictional interpretations of the American Civil War have Eiven, first, epolitical interpretation characterized by pertisanship and reconciliation; second, a psychological interpretation characterized by realism and sentimentalism; third, E political interpretation characterized by naturalism and humanitarianism; and fourth, a psychologicel interpretation characterized by naturelism and industrialism. It is reasonable to expect that, if interest in the Civil War continues, the altemation of political and nychological fictional interpretations will continue, also, and that the next years will produce nore political interpretations of the American Civil War.

2. The literary forms used in the fictional interpretations of the war have, in $g \in$ ne ral, been the forms available. The first period used the domestic novel, the 
objectively realistic novel, and the local color story; the second period, the short story; the third period, the historical romance; and the fourth period, the psychological novel. The chief innovations in literary form we re made by Stephen Vincent Eenet in his panoramic, ep ic poem, which he may have hoped would be used for a motion picture, and by Evelyn Scott in her tremendous, composite jicture of the war, a picture which is made up of more than sixty separate narratives.

Only two of the fictional interpretations of the war have become classics in American Iiterature: Ambrose Bierce's Tales of Soldiers and Civilians (1891) and Stephen Crane's The Red Badge of Courage (1895). Others which rise to distinction include: John William DeForest's Miss Ravenel's Conversion from Secession to Ioyalty (1867), Silas Weir Mitchel1's In War Time (1884), Winston Churchill's The Crisis (1901), Tpton Sinclair's Ianassas (1904), Mary Johns to n's The Iong Roll (1911) and Cease Firing (1912), Stephen Vincent Benet's John Brown's Body (1927), EveIyn Scott's The Wave (1929), Iackinlay Kantor's Iong Remember (1934) and Arouse and Beware (1936), Wiliiam Faulkner's The Envanquished (1938), and Allen Tate's The Fathers (1938).

3. The changing fictional interpretation of the war 
coincided with the historical interpretation. 1 The earIiest historians of the North blamed slavery for the war, and the earliest historians of the South pleaded State's Rights and defended the South on Constitutional grounds. Among these historians were John $W$. Draper, Alexander Stephens, and Jefferson Davis. Following ther, the history of the war was, for years, written almost entirely by Northemers of the Nationalist School. These historians passed sentence on the South as the assailant of nationality and as the defender of a decadent civilization. They pictured slavery $\varepsilon_{s}$ the great moral wrone of the age and interpreted the war as a struggle between the forces of light and darkness. They traced political and military history and rarely turned to the population outside the legislative halls and behind the $l$ ines of battle. Ferman Von Holst, James Schouler, John W. Burgess, and James Ford Ricodes are outstanding in the Nationalist School. Beginning in the late nineteentin and early twentieth centuries

I Hy surmary of his torical interpretations of the Civil War is besed both on my reading of the history itself and on (1) Michael Kraus, A Histony of American History (New York: Farrar and Rinehart, Inc., 1937) and (2) William T. Hutch inson, editor, The Marcus W. Jerregen Essays in American Historiography by $h$ is former students at the Eniversity of Chicago (Chicago: Lniversity of Chicago Press, 1937). I have not given the titles of the $h$ istories because they may be found in the works just cited and because many of them are in my bibliography. 
historians studied the var from other angles. They were more sympthetic with the South and with s lavery and they interpreted the war as a social revolution or as a part of the Industrial Revolution. John Bach Moliester, Woodrow Wilson, and Charles and hary Beard give social and economic interpretations of the war in contrast to the preceding moral and political treatments. Miore recently historians have made cereful studies of life in the old South, of the anti-slavery movenent, of foreign relations durine the war, of life in various sections of the country in the war period, and so on. Among these historians are William E. Dodd, Clrich Bonnell Phillips, Jesse Macy, Frank Lawrence $O_{\text {wsley, }}$, nd Arthur Charles Cole. The istorians who followed those of the Nationalist School have done much toward wiping out all the charges wich have been made against the Solith. They agree that, as actually carried out in the south, slavery was not an inhumane institution. What harshness and brutality there was carne, chiefly with three aspets -- slave crimes, runaways, and internal slave trade -- axpects wich did not touch the majority of the slaves. In additiou, these historians have pointed out that slavery has not dis appeared from the world even yet, 2 that it grew naturally in the South, and that before the Northern abolitionist interference South- 
erners were gradually doing away with slavery. Finally, recent historians have denied the great superiority in 1861 of Northern cul ture and education over Southern culture. They rank the South of 1861 very little, if any, behind the forth. Recent historians say that the Nor th and South simpiy had different civilizations and that the var succeeded in bringing the South closer to the Northem way of life and in making the Northern civilization the American civilization. It is easy to see the similarity between these changing historical interpretations and the fictional interpretations.

4. As for the lerêer, human significance of the American Civil war, neither the ljistorians nor the storywriters have attained the depth of insight which was expressed by two contemporaries. Walt Witman in is Ieaves of Grass and in $h$ is prose writings and Abraham Iincoln in his Second Inaugural Address have given us the noblest interpretations of the war in human terms. Both Northerners, they expressed the same admiration and hope for this democratic Inion that were expressed by the his torical romancers in the first decede of this century, but

It still exists in $n$ ineteen countries and holds in its grasp 5,000,000 people. - J. G. Randall, The Civil War and Reconstruction (New York: D. C. Heath and

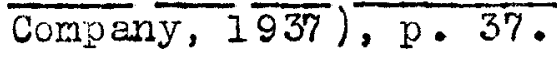


they went deeper.

The war strenethened Whitman's faith in this Democracy by strengthening $h$ is $i$ aith in tine common man. Witman said, "I never before so realized the majesty and reality of the American people en masse. . . It fell upon me like a great awe." 3 hitman did not fight in the war, but he served in the Cnion army as a nurse from 1862 to 1865. In "Drum Taps" he says:

Aroused and angry,

I thought to beat the al arurn, and urge relentless war,

But soon my fingers fail'd me, my face droop'd, and I resigned myself,

To sit by the wounded and soothe them, or silently

Witman's reactions to what he saw during his three years of nursine speak well for the character of the American people :

The novements of the late secession war, and their results, to any sense that studies well and comprehends them, show that popular denocracy, whetever its faults and dangers, practically jus tifies itself-beyond the proudest claims and wildest hopes of its enthusiasts. . . Descending to detail, entering any of the amies, and mixing with the private soldiers, we see and have seen august spectacles. We have seen the alacrity with which the American-born

3 Walt Witman, Autobiographia, p. 73. Quoted in Vemon Louis Parrington, Main Currents in Ame rican Thou sht (New York: Harcourt, Brace and Company, 1930), III, 77.

4 Walt Whitman, Leaves of Grass. (Philadelphia: Devid McKay, 1900), $p \cdot 240$. 
populace - . sprang, at the first tap of the drum, to ams . . We have seen the unequal'd docility and obedience of these soldiers. We have seen them tried long and long by hopelessness, mismanagenent, and by defeat; have seen the incredible slaughter toward or through which the amies . . unhesitatingly obey'd orders to advance. We have seen them in trench, or crouching behind breastwork, or tramping in deep mud, or amid pouring rain or thick-falling snow, or under forced marches in lottest summer.. . yet the great bulk bearing steadily on, cheery enough, hollow-bellied from hunger, but sinewy with unconquerable resoIution.

We have seen this race proved by wholesale by drearier, $y$ t more fearful tests - the wound, the amputation, the shatter'd face or limb, the slow hot fever, long impetient anchorage in bed, end all the forms of maiming. operation and disease. . . One night in the gloomiest period of the war, in the Patent office hospital in Washingtoncity, as I stood by the bedside of a Pennsylvania soldier, who lay, conscious of quick approachine death, yet periectiy calm, and with noble, spiritual manner, the veteran surgeon, turning aside, said to me, that though he had witnessid many, many deaths of soldiers, and had been a worker at Bull Run, Intietam, Fredericksbure, etc.. he had not seen yet the first cise or man or boy that met the approach of dissolution with cowardiy qualms or terror. iny own observation ful-y bears out the remark.

What have we here, if not, towering above all talk and argument, the plentifully-supplied, Iast-needed proof of democracy, in its personalities? Curiously enough, too, the proof on this point comes, I should say, every bit as mch from the south, as from the north. Although I have spoken only of the latter, yet I deliberately include all. Grand, common stock! to me the accomplish'd and convincing growth prophetic of the future; proof undeniable to sharpest sense, of perfect beauty, tenderness and pIuck, that never feudal lord, nor Greek, nor Roman breed, yet rival'd. Let no tongue ever speak in disparagement of the American races, north or south, to one who has been through the war in the great army hospitals. 5 
Iincoln, too, felt the suifering of humanty, North and South. His Second Inaugural Address, given March 4, 1865, closes with these timeless words:

With mal ice towards none, with charity for all, with firmness in the right as God gives us to see the right, let us strive on to $f$ in ish the work we are in, to bind up the nation's wounds, to care for him who shall have borne the battle, and for his widow and $h$ is orphans, to do all which may achieve and cherish a just and a lastine pe ace amone ourselves and with all nations.

5 Walt Whitman, "Democratic Vistas," in Prose Works

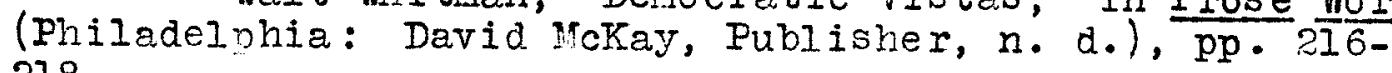
218 . 
BIBLIOGRAPHY 


\section{BIBLIOGRAPHY}

(NOW: In list of fiction is a selected, not a complete, bibliography. The sources of a full list of Civil War fiction are available. The best source, for fiction up to 1900, is Miss Smith's Doctoral dissertation. The sources for the period since 1900 include Baiker's Guide to Iistorical Fiction, library card catalogs (Iisted under Cnited States History, Civil War, Fiction), istories of American Iiterature, and megazines including American Literature, The Seturday Review of Literature, and The New Revubiic.)

\section{A. FICTION}

$$
1861-1879
$$

Baker, William Mumford, Inside. Wew York: Harper and Brothers, 1866 .

Beecher, Henry Ward, Norwood: Village Life in New England. (First published in 1867.) Reprinted from The New York Ledger, New York: Fords, Howard, and Hul bert, 1892 .

Clemens, Jeremiah, Tobias Wilson, A Tale of the Great Rebeliion. Philadelphia: J. B. Iippincott and Company, 1865 .

Crozier, R. H., The Confederate Spy; or Startling Incidents of the War Between the 3tates. First edition, 1866. Fifth edition, Louisville, Kentucky: John P. Morton and Company, 1885.

DeForest, John william, Miss Ravenel's Conversion from Secession to Loyalty. New Fork: Harper, $186 \%$.

French, Lucy Vire inia Snith, Kemwood, or After Many Days. Louisville, Kentucky: Published for the author by John P. Morton and Company, 1867.

Inolnes, Mary J., Rose Mather. (First edition, New York: Carleton, 1868) New York: G. W. Dill ingham, 1896. 
Jones, John Beauchamp, Wild Southern Scenes. Philadelphia: Petersen, 1859.

Kelso, Isaac, The Stars and Bars; or, The Reien of Terror in Missouri. Boston: A. Will iams, 1863 .

Russell, Charles vells, Roebuck. (First edition, New York: 14. Doolady, 1866.) Baltimore: Henry Taylor and Company, 1868.

Wheeler, A. 0., Eye-Witness; ox, Iife Scenes in the old Nor th State. Boston: B. B. Russell and Company, 1865 .

Vilson, Augusta Jane Evans, Macaria; or The Altars of Sacrifice. (First edition, Richmond: vest and Johnson, 1864.) New York: F. M. Iupton Publishing Company, 1896.

\section{$1880-1899$}

Bierce, Ambrose, Can Such Things Be?. (First published, 1893.) New York: Albert and Charles Boni, Inc., 7909 .

Bierce, Ambrose, Tales of Soldiers and Civilians (Iater changed to In the Midst of Iife). (First edition, San Francisco: Steele, I891.T New York: Putnam, 1901.

Crane, Stephen, Iittle Regiment and Other Episodes of the American Civil War. New York: Appleton, 1896.

Crane, Stephen, The Red Badge of Courage. (New York: Apple ton, 1895.) Fdited by Hax J. Ferzberg, New York: D. Apleton and Company, c. 1926.

Bgeleston, Geore Cary, Southern Boldier Stories. New York: The Macmillan Company, 1898.

Frederic, Harold, The Copperhe ad and Other Stories. New York: Scribner, 1893 .

Frederic, Harold, The Deserter and Other Stories. Boston: Lothrop Publishing Company, 1898 . 
Frederic, Harold, Marsena and Other Stories of the Wartime. New York: Scribner, 1894 .

Garland, Hamlin, "The Return of a Private" from Main Trevelled Roads. (First published, Boston, Arena Publishing Company, 1891.) New York: Harper and Brothers Publishers, 1930.

Mitcheld, Silas Weir, In Nar Time. (First edition, 1884.) Eleventh edition, INew York: The Century Company, 1912.

Page, Thomas Nelson, Burial of the Guns. New York: Charles Scribner's Sons, 1894.

$$
1900-1919
$$

Churchill, Winston, The Crisis. New York: The Macmillan Company, 1901.

Dreiser, Theodore, The Financier. Wew York: Harper, 1912.

Eggleston, George Cary, The Warrens of Virginia; New York: G. W. Dillingham Company, 1908 .

Glasgow, Ellen, The Battleground. New York: Doubleday, Page and Company, 1902 .

Johns ton, Mary. Cease Firing. Bos ton: Fou ghton Mifflin Company, 1912 .

Johnston, Mary, The Iong Roll. Boston: Hough ton Mifflin Company, 1911.

Molaws, Emily Lafayette, The Nelding. Boston: Iittle, Brown, and Comuan, 1907.

Sinclair, Tpton, Manassas. New York: The Macmillan Company, 1904.

Stephenson, Nathanie I, They. That Took the Sword. Iondon and New York: John Lane, The Bodley Head, 1901. 
$1920-1939$

Allen, Hervey, Action at Aquila. New York: Farrar and Rinehart, 1938 .

Benet, Stephen Vincent, John Brown's Body. New York: Doubleday, Doren and Company, Inc., I928.

Boyd, Tames, Marching On. THew York: C. Scribner's Sons, 1927.

Brier, Royce, Boy in Blue. New York: D. Appleton Century Company, Inc., 1937.

Dowdey, Clifford, Bugles Blow INo More. Boston: Iittle, Brow and Company, $193 \%$

Duff-Gordon, Caroline, iNone Shall Look Back. New York: Charles Scribner's Song, 1937.

Faulkner, Will iam, The Lnvanquished. New York: Random House, 1938.

Kantor, Mackinlay, Ione Remember. Wew York: The Literary Guild, 1934.

Kantor, MacKinlay, Arouse and Beware. New York: CowardMcCann, Inc., 1936.

Mitchell, Margaret, Gone with the Wind. New York: The Macmill on Company, 1936.

Scott, Evelyn, The Wave. Tew York: The Literary Guild of America, 1929 .

Tate, Allen, The Fathers. New York: G. Futnam's Sons, 1938.

Youne, Start, So Red the Rose. New York: Scribner, 1934. 


\section{B. IITERARY BACKGROCIND}

\section{Books}

Abbott, Lyman, Fenry Ward Beecher. Boston and New York: Houghton Mifflin and Company, November, 1903.

Beach, Seth Curtis, Daughters of the Puritans. Boston: American Lnitarian Association, 1905.

Beer, Thomas, Stephen Crane. A Study in American Letters, with an introduction by Joseph Conrad. New York: Garden City Publishing Company, Inc., 1927. (Published by Alfred A. Knopf, Inc., 1923).

Benedict, Clare, Constance Fenimore Woolson. Iondon: Fllis, 29 Bond street, n.d.

Prowne, Charles Farrer, Artemus Ward, His Book. New York : Carleton, 1862.

Purr, Anna Robeson, Weir Mitchell, His Life and Letters. New York City: Duffield and Company, 1929.

Dell, Floyd, Epton Sinclair. A Study in Social Protest. New York: George H. Dor an Company, 1927.

Fitzhugh, Harriet Iloyd and Percy K., Concise Biographical Dictionary. New York: Grosset \& Dunlap, 1935.

Grant, Llysses S., Personal Memoirs of C.S. Grant. New York: C. I. Webster and Compan, $1885-86.2 \mathrm{v}$.

Grattan, C. Hartiey, Bitter Bierce. A Hystery of American Letters. Garcien City, Wew York: Doubleday, Doran \& Company, Inc., 1929 .

Halpine, Charles Graham, The Iife and Adventures, Songs, Services, and Speeches of Private Miles O'Reilly. New York: Carieton, 1864 .

Hatcher, Harlan, Creating the Modern American Novel. New York: Farrar and Rineinart, On Jurray Fill, 1935.

Howes, Durward, editor, America's Young Men. Ios Angeles, California: American Publications, Inc., 1938. 
Johnson, Allen, editor, Dictionary of American Biosraphy. New York: Charles Scribner's Sons, 1928.

Knight, Grant $C$., James Iane Allen and the Genteel Tradition. Chapel Hill: The Lniversity of North Carolina Press, 1935.

Locke, David Ross, The Hasby Papers. Indianapolis, Indiana: Perrine, 1864.

Marquis, Albert Nelson, editor, Who's ino in America. Chicago: The A. N. Marquis Company, 1899-1939. Revised and reissued biennially.

Mayo rga, Margaret G., A Short History of American Drama. New York: Dodd, Mead \& Compeny, 1932.

Moses, Montrose James, The Iiterature of the South. New Yorik: T. Y. Croweli \& Comany, 1910.

Newell, Robert Henry, The Oroheus C. Kerr Papers. New York: Carleton, 1871. TOriginal edition, New York: BI akemore and Mason, 1862-1865.)

Pattee, Fred Lewis, The Deve lopment of the Ame rican Short Story. Tew York and Iondon: Harper and Brothers,

Pattee, Fred Lewis, A History of American Literature. ITew York, Boston, etc.: Silver, Burdett, and Company, 1903.

Pattee, Fred Lewis, A History of Ane rican Literature Since 1870. New York: The Century Company, 1915.

Pattee, Fred Lewis, The New Anerican Iiterature, 1890-1930. New York: The Century Company, 1930.

Farrington, Vermon Louis, Main Currents in American Thought. New York: Farcourt, Brace and Company, $1927-1930.3 \mathrm{v}$.

Fickett, LaSalle Corbell, Iiterary Hearthstones of Dixie. Philadelphia and London: J. B. Iipp incott company, 1911, 1912. 
Quinn, Arthur Fobson, A History of American Drama from the Civil War to the Present Day. 2 vols.; New York and London: Haryer and Brothers, Publiskers, 1927.

Rascoe, Burton, Theodore Dreiser. New York: R. 2if. McBride and Company, 1925.

Sinclair, Cpton, American Outpost. A Book of Reminiscences. Nivw York: Farrar and Rinehart, Inc., 1932.

Smith, Charles Henry, Bill Arp. So-called. A Side show of the Southern Side of the War. iNew York: Metropolitan Record Office, 1866.

Suttner, Berthe von, Ground Arms!. The Story of a Iife. Chicago: A. C. McClurg \& Company, 1802. Translated from the German by Alice Asbury Abbott.

Tante, Dilly, editor, Living Authors. Nevw York: The H. i. Wilson Company, 1.931 .

Van Doren, Carl, American and Eritish Iiterature Since 1890. New York and Iondon: The century Company, 1925 .

Van Doren, Carl, The Americen Movel. New York: The Macmilian Company, 1921 .

- Van Doren, Carl, Contemnorary American Novelists 1900-1920. The Macmillan Company, 1922.

Verd, 필abeth Stuart Phelns, Chapters from a Iife. Boston and New York: Hough ton Mifflin Company, 1896.

Witman, Walt, Leaves of Grass. Philadelphia: David MicKay, 1900 .

1

Witman, Walt, Prose Works. Philacelyhia: David IoKay, Publisher, n.a.

Witman, Walt, Walt Witman and the oivil War. A collection of oriéinal articles and nanuscrits, edited by I. Glicksbere. Philadelphia: Lniversity of Pennsylvania Press, 1933. 


\section{z. Periodical Articles}

Benet, Stephen Vincent, "A Review of Gone with the Wind," Saturiay Review of Iiterature, $14: 5$, July 4, 1936.

Boyle, Kay, "Tattered Banners," The New Renublic, 94 :136137, Merch 9, 1938.

Collins, Dorothea Prande, "Review of None Shall Iook

Back, "American Review, $8: 497$, February, 1937 .

Cowley, Malcolm, "Civil War Movie," The New Repuolic, $94: 138-140$, March 9, 1938.

Ford, Paul Leicester, "The American Historical Novel," The Atlantic Monthly, $80: 721-728$, December, 1897 .

Kunitz, Stanley J., editor, "Caroline Gordon, "Wilson Bulletin, I2:10, September, $193 \%$.

Loveman, Amy, "The Clearing House," Saturday Review of Literature, $14: 19-20$, October 17,$1936 ; 15: 18$, October 31,$1936 ; 15: 20$, February 6, 1937 .

Lovett, Robert Morss, "A Review of The Wave," The New Republic, $59: 319$, August 7, 1.929 .

NoCarthy, Nary, "A Review of so Red the Rose, "Nation, $139: 167$, August $8,1934$.

Mitchel1, Margaret, "Wargaret Mitchell, "Wilson Bulletir, 11 :12, September, 1936.

Rosenbaum, Belle, "Why Do They Read It?," Scribner's

Magazine, $102: 23$, August, 1937 .

"Wilt, Napier, "Ambrose Bierce and the Civil War," American Literature Magazine, $1: 260-285$, March, 1929, -Jenua $\mathrm{M}, 1930$.

\section{Encyclopedia Articles}

She man, Stuart F., "Mark Twain," The Cambridge History of American Iiterature, III, 3 . 
Van Doren, Carl, "The Later Irovel," The Cambriage History of American Iiterature, III, 66-05.

\section{Tnpublished Materials}

Smith, Rebeca Washington, "The Civil War and Its Aftermath in American Fiction, 1861-1899, with a Dictionary Catalogue and Indexes." Tnpublished Doctor's dissertation, Cniversity of Chicego, Chicago, Illinois, 2.932.

\section{Newspapers}

INew York Times, May 8, 1934.

Time, 33 :91, April 24, 1939.

\section{HISTORICAI BACKGROLID}

1. Books

Beard, Charles and Mary, The Rise of imerican Civilization. New York: The Mecmilian Company, 1935.

Buck, PavI H., The Road to Reunior, 1865-1900. Boston: Iittle, Brown and Company, 1937.

Cole, Arthur Charles, The Irrepressible Conflict, 18501865. VoI. VII, A History of American Iife. New York: The Macmilian Company, 1934.

'Comager, Henry Steele, editor, Documents of American History. New York: I. S. Crofts and Company, 1934.

Connelley, William Flsey, and E. M. Coulter, History of Kentucky. Edited by Judge Charles Kerr. New Yori : American $\mathrm{His}$ torical Society, 1922 . 
Dodd, villiam $\mathrm{B}$., The Cotton Kingdom. The Chronicles of Americe Series, A Ien Johnson, editor. New Haven: Yale Tniversity Press, 1919.

Hancock, Comelia, South after Gottysburg. Philadelphia: University of Pennsylvania Press, 1937.

Farlo:, Ralph Volney, The Growth of the Lnited States. New York: Henry Holt and Company, 1925 .

Hutchinson, William T., Editor, The Marcus H. Jemegan Essays in Historiography by his fomer students at the University of Chicago. Chicago: The Iniversity of Chicago Press, 1937.

Kraus, Michael, A History of American History. New York: Farrar and Rinehart, Inc., 1937 .

Macy, Jesse, The Anti-Slavery Cmusede. The Crronicles of America Series. New Haven: Yale Lniversity Press, 1.919 .

Owsley, Frank Iawrence, King Cotton Diplomacy, Fore ign Relations of the Confecerate 3 tates of America. Chicago: Iniversity of Chicago Press, 1931.

Owsley, Frank Lawrence, State Rights in the Confederacy. Chicago: The University of Chicago Press, 1925.

Phillips, Clrich Bonnell, Iife and Labor in the old South. Copyright 1929. Boston: Iittle, Brown and Company, 1931.

Rendall, J. G., The Civil War ain Reconstruction. New York: D. C. Heath and Company, 1937 .

. Rhodes, James Ford, Iectures on the Arerican Civil war, Delivered before the Lniversity of Oxford in Easter and Trinity Terms, 1912. Hew York: The vicmillan Companj, 1913.

Stephenson, Nathaniel $\mathrm{W} .$, The Day of the Confederacy, A Chronicle of the Embattled South. The Chronicles of America Series, Allen Johnson, editor. New Haven: Yale Lniversity Fress, 1919. 
Sterhenson, Nathaniel W., A History of the American People. New York: Charles Scrioner's Sons, 1934 .

Ste phenson, Nathaniel $\%$, Iincoln and the Lnion, A Chronicle of the Embattled Worth. The Chronicles of America Series, Allen Johnson, editor. New Haven: Yale Lniversity Press, 1918.

\section{Periodical Articles}

Coulter, E. Merton, "What the South Hes Done cibovt Its His tory, "Joumal of Southern His tory, $2: 3-\varepsilon 8$, February, 1936 .

Hogan, William Ransom, "Amusements in the Repulicic of Texas, " Joumal of Southern His tory, $3: 397-421$, No veriber, 1937 .

Rabert, Joseph C., "Lee the Farmer," Journal of Southerm History, $3: 422-440$, Tovember, 1937 .

\section{Famphlet}

Iincoln, Abraham, Second Inaucural Address. Mfarch 4, 1865. Pamphle $\bar{t}$ issue $d$ by Americanization Department, Veterans of Foreign Wars of the Inited States. No place of publication given, n.d. 